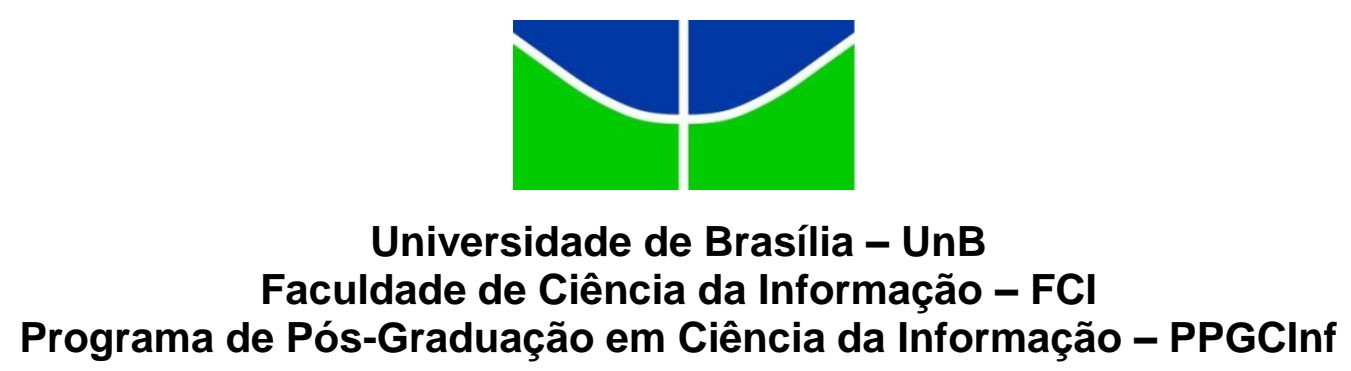

VIVIANNE DA ROCHA RODRIGUES

COMUNICAÇÃO E MEDIAÇÃO ENTRE A CRIANÇA DA PRIMEIRA INFÂNCIA E A INFORMAÇÃO DIGITAL NA EDUCAÇÃO INFANTIL

BRASÍLIA

2015 
VIVIANNE DA ROCHA RODRIGUES

\title{
COMUNICAÇÃO E MEDIAÇÃO ENTRE A CRIANÇA DA PRIMEIRA INFÂNCIA E A INFORMAÇÃO DIGITAL NA EDUCAÇÃO INFANTIL
}

\begin{abstract}
Dissertação apresentada ao Programa de PósGraduação em Ciência da Informação da Universidade de Brasília - UnB, como requisito parcial para obtenção do grau de Mestra em Ciência da Informação.
\end{abstract}

Orientadora: Prof. ‥ Dra. Ivette Kafure Área de concentração: Gestão da Informação

BRASÍLIA

2015 
Ficha catalográfica

R696c Rodrigues, Vivianne da Rocha,

Comunicação e mediação entre a criança da primeira infância e a entre a criança da primeira infância e a informação digital na educação infantil / Vivianne da Rocha Rodrigues. - Brasília: UnB, 2015. 85 f. il. ; $30 \mathrm{~cm}$.

Dissertação (Mestrado em Ciência da Informação) Universidade de Brasília, Faculdade de Ciência da Informação, Brasília, 2015.

Orientadora: $\operatorname{Prof}^{\mathrm{a}} \mathrm{Dr}^{\mathrm{a}}$ Ivette Kafure Muñoz.

1. Comunicação e mediação da informação. 2. Criança da primeira infância. 3. Informação digital. 4. Educação infantil. 5. Jogos. I. Título. 


\section{FOLHA DE APROVAÇÃO}

Título: Comunicação e mediação entre a criança da primeira infância e a informação digital na educação infantil

\section{Autor (a): VIVIANNE DA ROCHA RODRIGUES}

Área de concentração: Gestão da informação

Linha de pesquisa: Comunicação e Mediação da Informação

Dissertação submetida à Comissão Examinadora designada pelo Colegiado do Programa de Pós-graduação em Ciência da Informação da Faculdade em Ciência da Informação da Universidade de Brasília como requisito parcial para obtenção do título de Mestre em Ciência da Informação.

Dissertação aprovada em: 29 de maio de 2015.

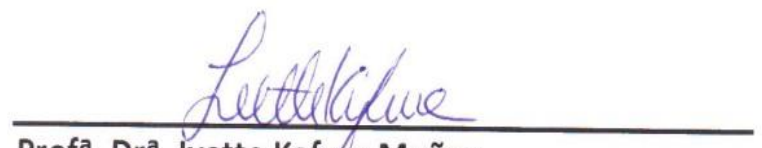

Profa. Dra. Ivette Kafure Muñoz

Presidente (UnB/PPGCINF)

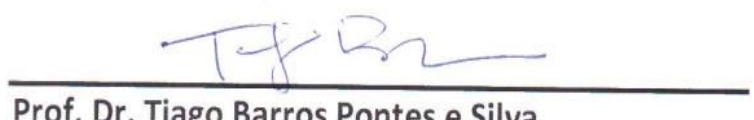

Prof. Dr. Tiago Barros Pontes e Silva

Membro Externo (NESP)

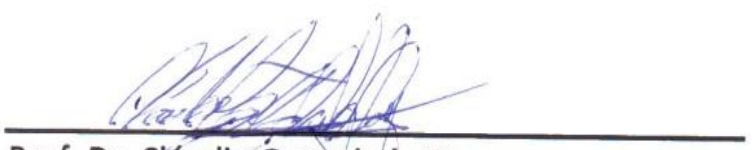

Prof. Dr. Cláudio Gottschalg-Duque

Membro Interno (UnB/PPGCINF)

Prof. Dr. Jorge Henrique Cabral Fernandes

Suplente (UnB/PPGCINF) 
À Emanuelle inspiração deste trabalho e da minha vida. À bibliotecária, professora e amiga Ilza Leite Lopes (in memoriam). 


\section{AGRADECIMENTOS}

Agradeço imensamente a Deus por ter me dado forças para concluir e por ter permitido encontrar pessoas iluminadas em meu caminho.

Agradeço minha família pela paciência e força.

À Capes pela bolsa concedida.

A dona Vera, diretora da Escola Ursinho Dourado, pelo espaço e confiança.

À diretora da Escola Franciscana Nossa Senhora de Fátima, Irmã Inês.

Ao Colégio Santa Maria, representado pela professora llma e ao responsável pelo laboratório, Júnior.

Ao Colégio La Salle Brasília, à coordenadora geral Ivana, à coordenadora da educação infantil Ana Rita. E ao professor Tiago que exerce com maestria seu trabalho com alunos da educação infantil do La Salle Brasília.

À Ivette Kafure por ter orientado e acreditado no meu potencial mais do que eu mesma, sempre.

Aos professores Claúdio Gottschalg e Tiago Barros por compor minha banca e pelas preciosas contribuições para o meu trabalho.

À Yaci, bibliotecária mais incrível que conheço, por estar sempre ao meu lado me apoiando e alegrando minha vida.

Aos meus amigos queridos e amados bibliofriends: Ana Flávia, Jonniery, Fabiane, Wanne, Mariana, Tainá, Alan e Diego.

Às bibliotecárias amigas Lindalva e Chirlene pelo incentivo.

As queridonas Kerlla, Alessandra e Lorena por terem suportado minhas queixas. Obrigada pelos conselhos e ajuda meninas!

À Suzana, Luísa e Carol.

Aos meus amigos do IESB: Ana Paula, Hagna, Antonio Henrique, Hurlei, Jefferson, Rony, Raissa, Lana, Eduardo, Evandro, Pedro e Alam pelo apoio.

Às calouras bibliotecárias queridas Priscylla e Alanna pela força nos momentos finais.

Obrigada a todos!! 


\section{[...]}

Eu quero

Mais...

Brincar.

Dizer o que penso.

Fazer o que quero.

[...]Transformar este mundo.

Fazer um novo atlas da vida...

Eu

Vivo

Brinco.

Pinto, desenho, modelo.

Jogo.

Faço de conta que...

Viajo a outros mundos.

Peço para que...

Pesquiso e descubro o mundo.

Amo.

[...]

De você.

Eu peço

Olhem para mim e me veja por dentro. Me ouça e tente me entender.

Eu sou

Assim mesmo.

Criança.

Jovem.

Inteiro.

Eu sou.

E você?

(Trechos do texto "Carta de uma criança que ainda há de ser" escrita por Adriana

Friedmann). 


\section{RESUMO}

O objetivo de pesquisa consiste em identificar as estratégias de comunicação e mediação entre a criança da primeira infância e a informação digital no âmbito escolar infantil. Para que o mesmo fosse atingido na fase de pré-teste utilizou-se de observações assistemáticas de aulas no laboratório de informática no Colégio Santa Maria situado na cidade satélite de Santa Maria Distrito Federal, por dois dias durante três semanas no final do mês de maio e início de junho de 2014, com intuito de testar o método e validá-lo para coleta definitiva. Nesta etapa foram observadas turmas de educação infantil com crianças entre três e cinco anos de idade. Como resultado preliminar notou-se algumas reações emocionais por parte das crianças na interação com os jogos e entre elas. Observaram-se, também, alunos entre quatro e cinco anos da educação infantil do Colégio La Salle de Brasília durante duas segundas-feiras do mês de setembro. Neste as crianças utilizam jogos do smartkids selecionados pelo professor com propósito de aprenderem a formar palavras associadas com as figuras correspondentes e as pronúncias reforçando as aulas de português, no caso ou outros jogos quando a intenção de reforçar outra disciplina. Após a realização da atividade selecionada os alunos puderam jogar no site de jogos friv, porém com restrições há alguns jogos. Em maio de 2015 realizou-se a coleta final no Colégio La Salle de Brasília em uma turma de infantil IV. Em todas as observações as crianças interagem, hora com a "informação digital", entre elas e o professor. Percebeu-se que as principais estratégias de comunicação e mediação da informação utilizadas são a disponibilização de vídeos, jogos e demais informações digitais lúdicas.

Palavras-chaves: Comunicação e mediação da Informação. Criança da primeira infância. Informação digital. Educação infantil. Jogos. 


\begin{abstract}
The research goal is to identify how the communication and mediation strategies between a child early childhood and digital information no infant school scope. So that it was reached in the pretest phase was used to unsystematic notes not computer lab classes without college located in Santa Maria city satellite Santa Maria Federal District, in two days during three weeks of may no definitive month home and june 2014, with the purpose of test method and validates it final paragraph collection. At this stage were observed childhood education classes with children between three and five years of age. as preliminary result was noted some emotional reactions by children in interaction with and between games them. They observed, also, students between four and five years of early childhood education from La Salle College of Brasilia, two mondays for month september. This how children use selected SmartKids hair teacher games with purpose to learn one forming words associated with figures such as correspondents and as reinforcing pronunciations portuguese classes, not if or other games when an intention to strengthen another discipline. After a realization of selected os activity students could play any site friv games, but with no restrictions some games. In may 2015 we held a final at La Salle College of Brasilia in a group of children infant IV. In all comments as children interact, time with one teacher and "digital information" between them. He was noticed que main strategies of communication and mediation of information used are the availability of videos, games and other recreational digital information.
\end{abstract}

Keywords: Communication and mediation of information. Early childhood child. Digital information. Childhood education. Games. 


\section{LISTA DE FIGURAS}

Figura 1 Proporção de crianças que utilizam computador disponibilizado pelo TIC Crianças 2010.

Figura 2 Local de uso individual da internet e local mais frequente (\%)..................16

Figura 3 Modos de obtenção das habilidades para uso das TIC.............................16

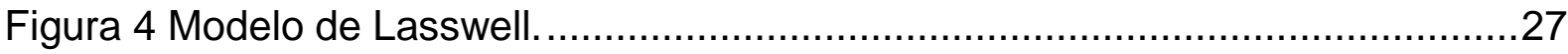

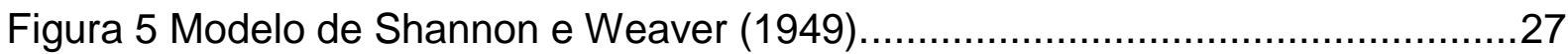

Figura 6 Modelo Funcional de Ruesch e Bateson (1951). ...................................28

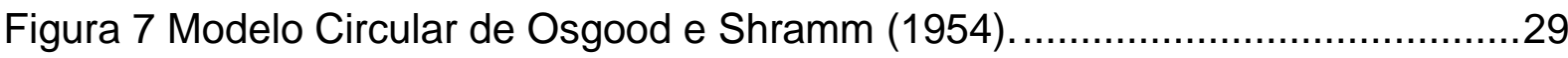

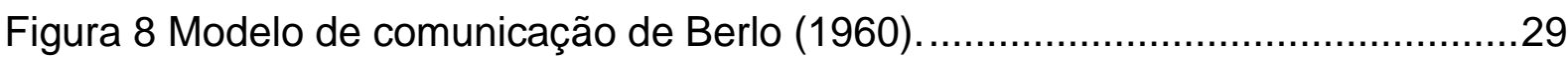

Figura 9 Modelo helicoidal de Dance (1967) .....................................................30

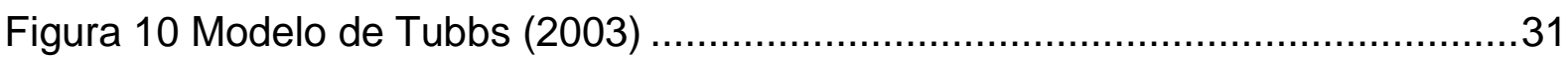

Figura 11 Modelo espiral/helicoidal proposto por Piaget........................................33

Figura 12 elementos envolvidos no processo de interação....................................43

Figura 13 modelo mental apresentado por Kafure em sua tese em relação às necessidades e as expectativas dos usuários de Catálogo Público de acesso em Linha (OPAC) em bibliotecas 44

Figura 14 Questionário para as crianças na escola Ursinho Dourado ......................49

Figura 15 tela da interface em que se encontram os jogos no smartkids.................50

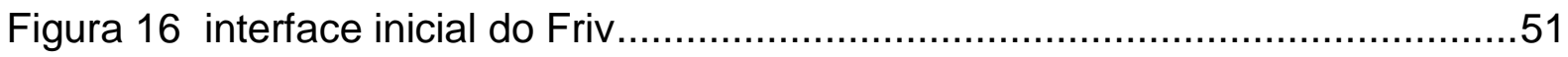

Figura 17 atividade aplicada aos alunos da Escola Franciscana Nossa Senhora de Fátima 53

Figura 18 Modelo de comunicação e mediação entre a criança e a informação ......66 


\section{LISTA DE QUADROS}

Quadro 1 Pensadores e suas contribuições educação, sociedade e concepção da

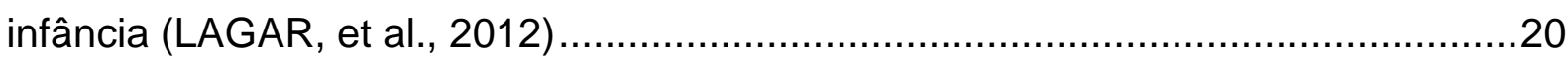

Quadro 2 Estágios do desenvolvimento cognitivo de acordo com Piaget ...............23

Quadro 3 Relação ferramentas de comunicação e elementos envolvidos nesse processo de mediação da informação.....................................................................

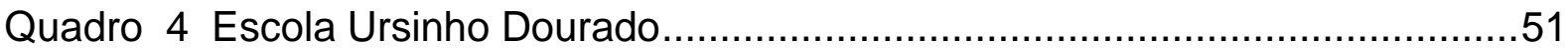

Quadro 5 Escola Franciscana Nossa Senhora de Fátima........................................54

Quadro 6 Crianças do Maternal III - Colégio Santa Maria ....................................55

Quadro 7 Crianças do Jardim IA - Colégio Santa Maria .......................................56

Quadro 8 Crianças do Jardim IB - Colégio Santa Maria ........................................57

Quadro 9 Crianças Jardim II - Colégio Santa Maria ...........................................57

Quadro 10 Crianças Jardim IIA - Colégio Santa Maria ........................................57

Quadro 11 Colégio La Salle Brasília Infantil IV ...................................................59

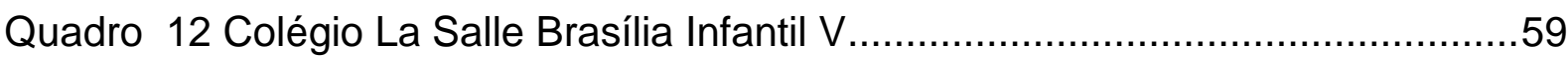

Quadro 13 Jogos trabalhados com os pequenos alunos do colégio La Salle de

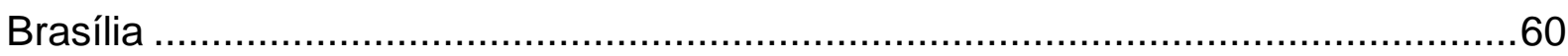

Quadro 14 Jogos do site de jogos Friv utilizados pelas crianças de todas escolas .60

Quadro 15 Observações La Salle 7 maio 2015 .................................................64

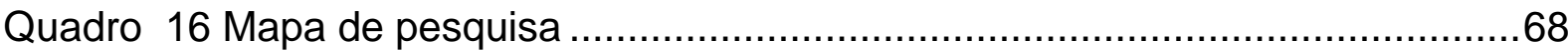




\section{LISTA DE ABREVIATURAS E SIGLAS}

Cl Ciência da Informação

CGI.br Comitê Gestor da Internet no Brasil

TIC Tecnologia da Informação e Comunicação

PPP Projeto Político Pedagógico 


\section{SUMÁRIO}

1 INTRODUÇÃO

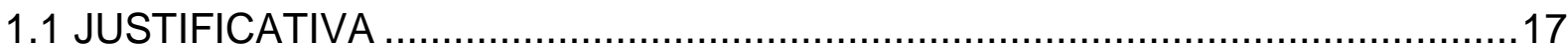

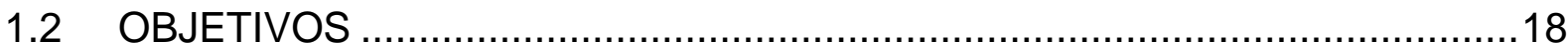

2 REVISÃO DE LITERATURA

2.1 INFÂNCIA, CRIANÇA, EDUCAÇÃO E TECNOLOGIA …................................19

2.2 COMUNICAÇÃO E MEDIAÇÃO DA INFORMAÇÃO E A CRIANÇA DA

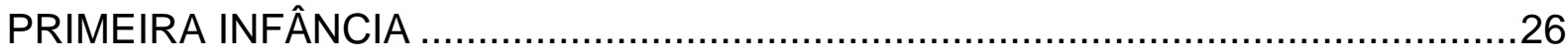

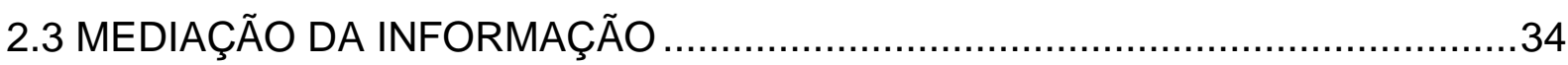

2.4 ESTRATÉGIAS DE COMUNICAÇÃO E MEDIAÇÃO DA INFORMAÇÃO.............35

2.5 INFORMAÇÃO DIGITAL NAS ESCOLAS DE EDUCAÇÃO INFANTIL ................36

2.6 FATOR EMOCIONAL E COMPORTAMENTAL NA INTERAÇÃO ENTRE A

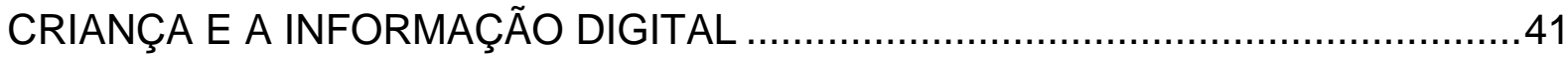

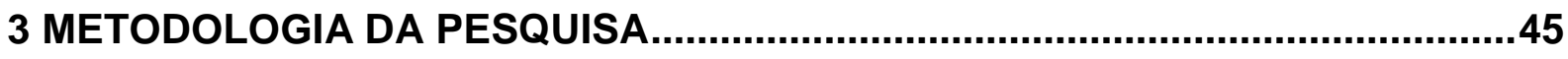

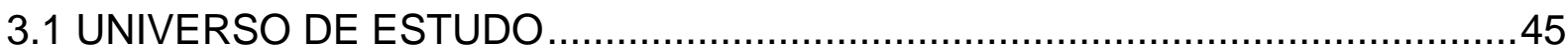

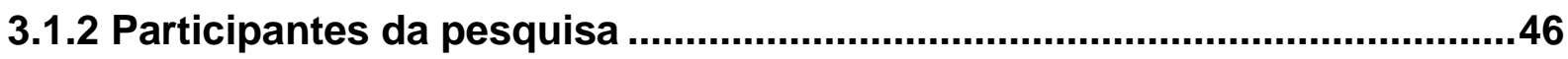

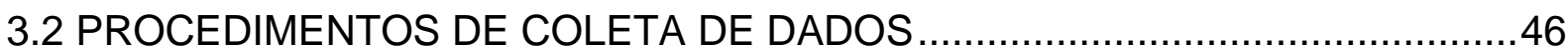

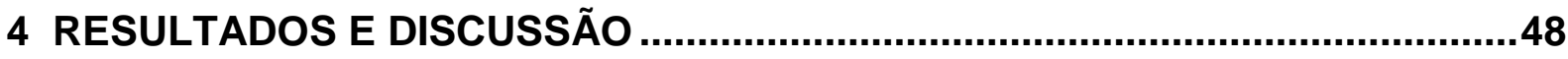

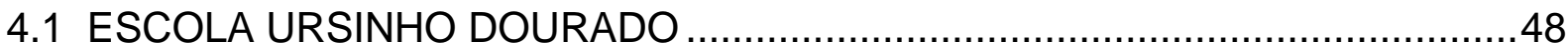

4.2 ESCOLA FRANCISCANA NOSSA SENHORA DE FÁTIMA ….........................52

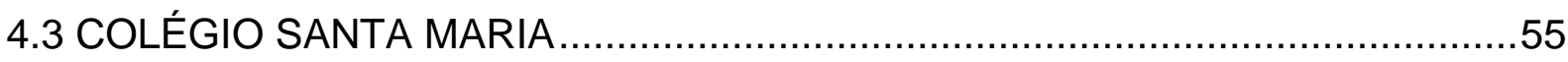

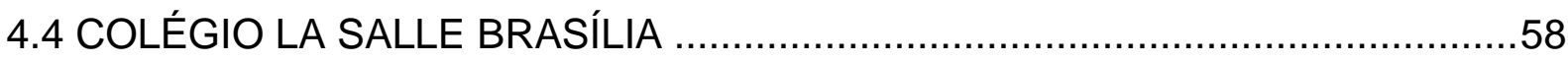

4.5 PROPOSTA DE MODELO DE ESTRATÉGIA DE COMUNICAÇÃO E MEDIAÇÃO ENTRE A CRIANÇA DA PRIMEIRA INFANCIA E A INFORMAÇÃO

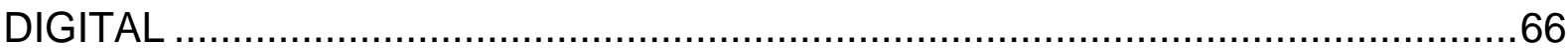

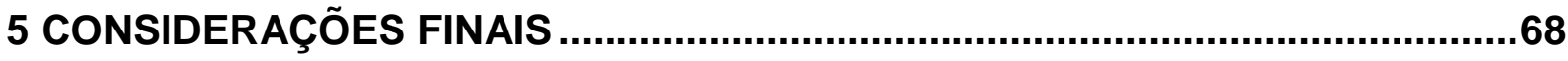

REFERÊNCIAS

ANEXOS 


\section{INTRODUÇÃO}

O progresso científico trouxe consideráveis mudanças nos meios de comunicação com a inserção de diversos aparelhos tecnológicos, atingindo quase todos os setores da sociedade. Por exemplo, na medicina, com aparelhagem específica de alta precisão para realização de cirurgias imagináveis ou com alto grau de complexidade causada por uso de métodos e instrumentos nos procedimentos invasivos; no processo eleitoral; na educação graças aos variados recursos criados e disponibilizados nas aulas; nos meios e formas de comunicação, principalmente.

A informação se torna disponível, devido à facilidade de ter contato com aparatos tecnológicos como smartphones, tablets, notebooks, netbooks, ultrabooks, leitores de e-books, videogames, televisor digital dentre outros e há ainda, a disponibilização de terminais digitais em bibliotecas públicas e escolas o que possibilita a acessibilidade democrática da informação.

As crianças da primeira infância acessam em casa e ou na escola informações digitais como jogos, música, vídeos, filmes, aplicativos dentre outras. Diante deste cenário é relevante estudá-las como usuárias de informação.

Em entrevista ${ }^{1}$, o escritor e educador Rubem Alves (2012) contesta o modelo tradicional de educação e um dos trechos alerta para a necessidade dos professores aprenderem a ouvir as interrogações das crianças. Por que não ouvi-las? Estudálas como usuárias de informação? Ver como ocorre a comunicação e mediação da informação no contexto infantil? Na literatura em Ciência da Informação $(\mathrm{Cl})$, há poucos trabalhos relacionados aos estudos de usuários infantis e ao uso de informações pelas crianças, assim como necessidade informacional e competência e comportamento informacional sobre os pequenos.

Instituições de ensino particulares e públicas estão preocupadas com a mudança na forma atual de educar e o novo contexto digital vivido pelas crianças, essas escolas agregam instrumentos digitais e consequentemente a informação digital, como jogos, histórias, fábulas e outros, na internet considerando-os recursos pedagógicos. Porém, as crianças estabelecem maior contato com Tecnologia da Informação e Comunicação (TIC) em casa jogando, vendo filmes, ouvindo música. A

\footnotetext{
${ }^{1}$ Entrevista concedida em 12 de agosto de 2012 ao Globo News Dossiê. Disponível em: $<$ http://g1.globo.com/globo-news/jornal-globo-news/videos/t/todos-os-videos/v/v/2107811/ >. Acesso em: 10 julho de 2014.
} 
pesquisa TIC Domicílios realizada pelo Comitê Gestor da Internet no Brasil (CGI.br) aponta o crescimento do uso das TICs desde 2005 nas residências do país. Já no TIC Crianças 2010, também realizada pelo CGl.br, sugere a imersão das tecnologias entre as crianças. A porcentagem de crianças que acessam o computador correspondeu a $51 \%$ das respostas dadas pelos usuários infantis (conferir figura 1), porém, $27 \%$ delas afirmaram que usam internet. Um número significativo de crianças estudadas acessa a internet de casa (verificar figura 2) e 20\% (ver figura 3) aprendem utilizar as TIC's sozinhas. Existem alguns sites com jogos/atividades educativas disponíveis, como o smartkids ${ }^{2}$, racha cuca ${ }^{3}$, escola games ${ }^{4}$, jogos educativos nova escola ${ }^{5}$, dentre outros. O estudo indica que $90 \%$ das crianças, quando estão no computador/internet, jogam online e 34\% assistem vídeos, animações de desenhos e filmes infantis (COMITÊ GESTOR DA INTERNET NO BRASIL, 2012).

Figura 1 Proporção de crianças que utilizam computador disponibilizado pelo TIC Crianças 2010.

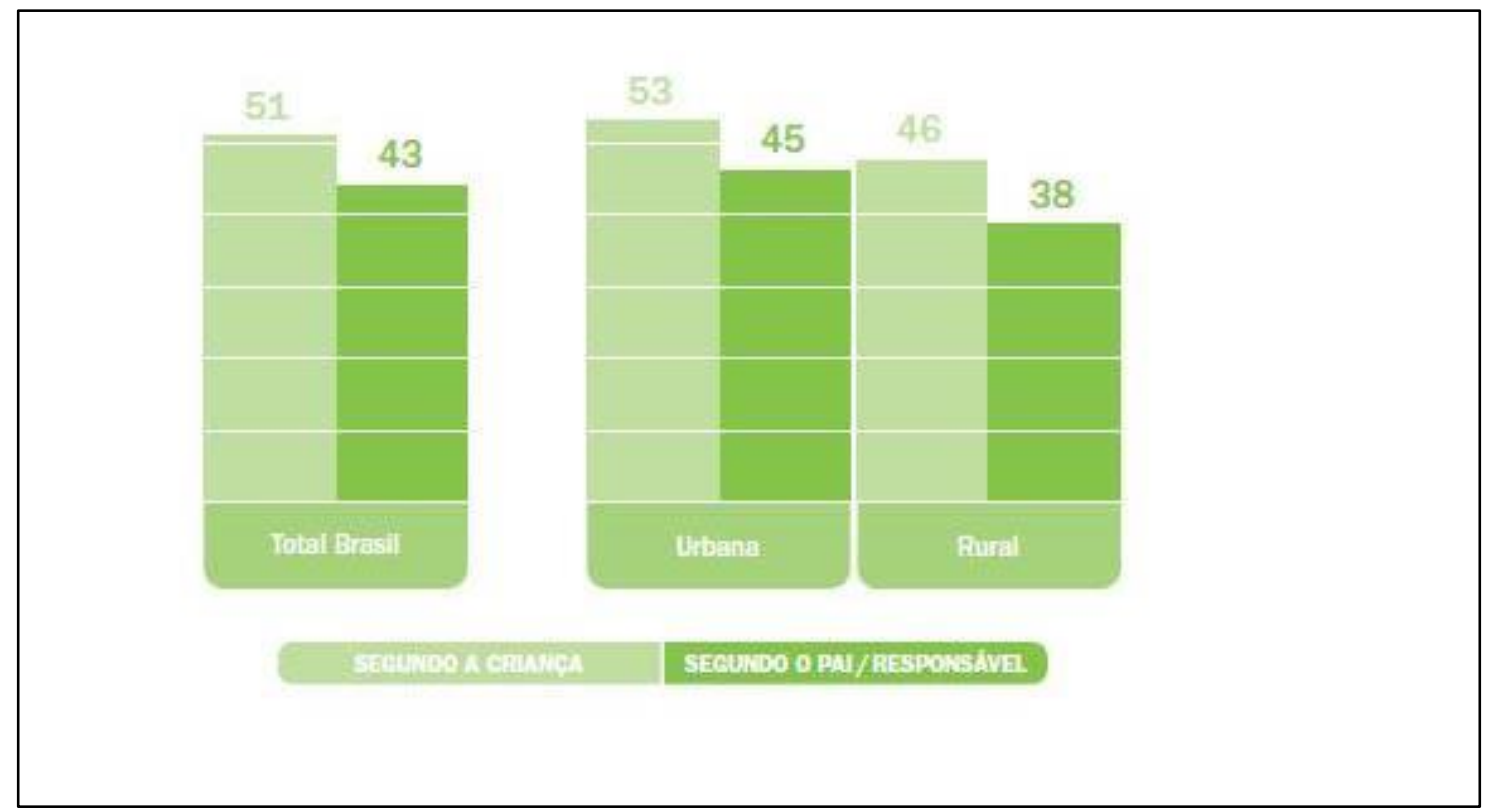

Fonte: COMITÊ GESTOR DA INTERNET NO BRASIL, TIC Crianças 2010.

Os números apontados pelas pesquisas do CGI.br de acesso às TIC's pelas crianças mostram uma demanda real de compreensão do fenômeno. O desenvolvimento desta pesquisa parte do entendimento da realidade mencionada.

\footnotetext{
${ }^{2}$ Disponível em: http://www.smartkids.com.br/

${ }^{3}$ Disponível em: http://rachacuca.com.br/

${ }^{4}$ Disponível em: http://www.escolagames.com.br/

${ }^{5}$ Disponível em: http://revistaescola.abril.com.br/jogos/
} 
Figura 2 Local de uso individual da internet e local mais frequente (\%)

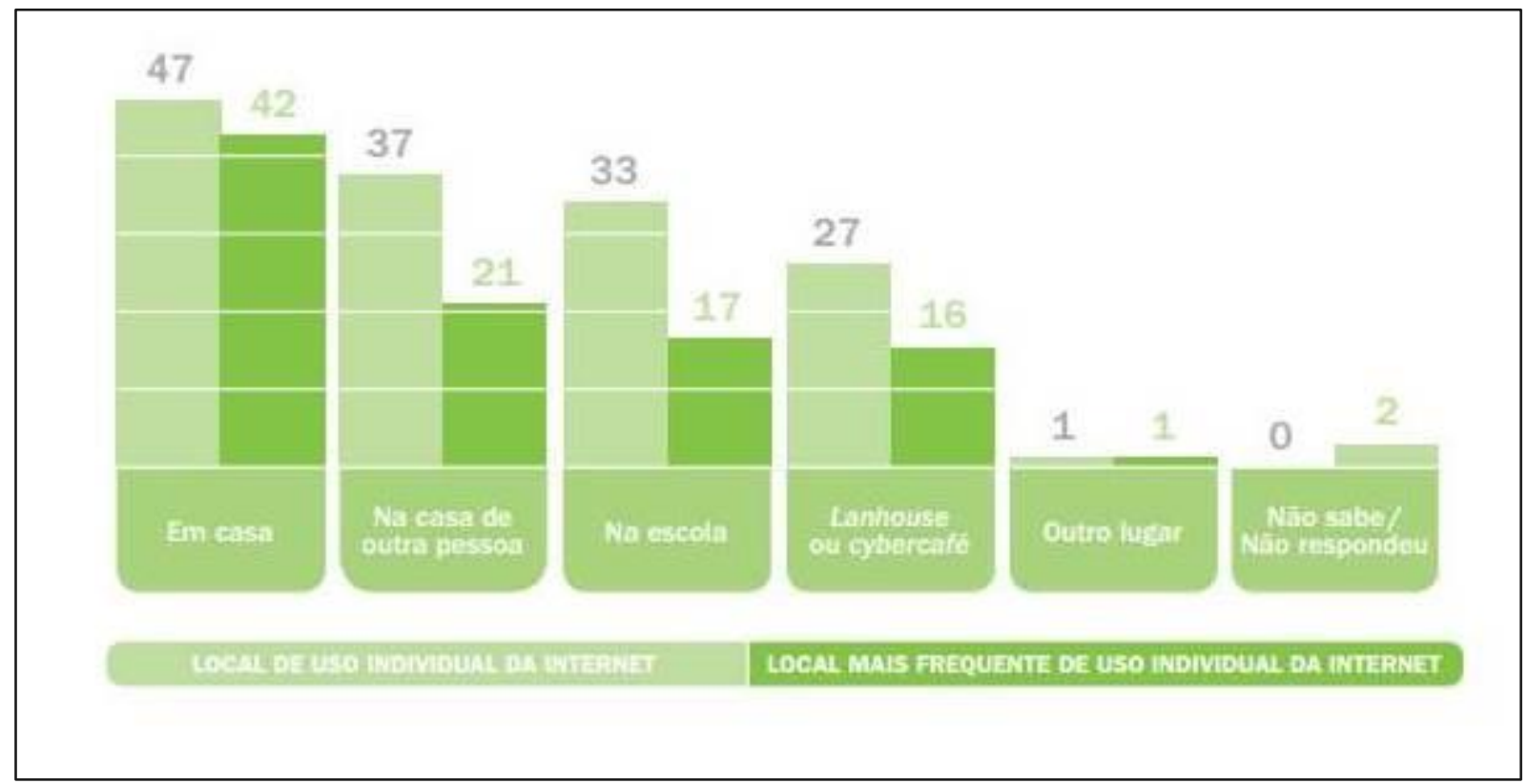

Fonte: COMITÊ GESTOR DA INTERNET NO BRASIL, TIC Crianças 2010

Figura 3 Modos de obtenção das habilidades para uso das TIC

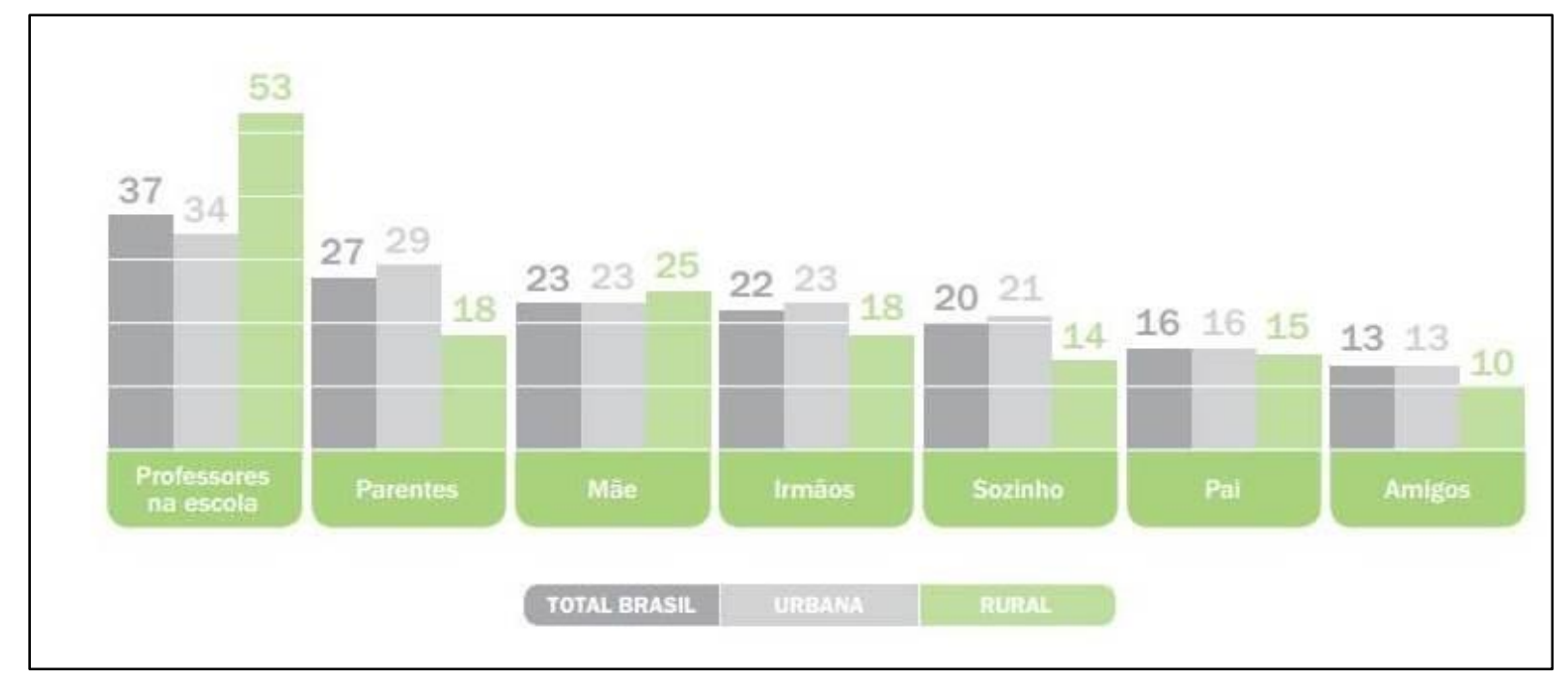

Fonte: COMITÊ GESTOR DA INTERNET NO BRASIL, TIC Crianças 2010

No decorrer da pesquisa são apresentados temas relacionados ao uso de informação digital pela criança da primeira infância e alguns dados levantados durante curto período de tempo em campo. Para construção da revisão de literatura ponderou-se em textos das áreas de ciência da informação, educação, psicologia e tecnologia da informação. 
Para o pré-teste considerou-se trabalhos elaborados por Rodrigues em 2012 e 2013 pertinentes ao tema de pesquisa, além de observações em mais duas instituições de ensino que oferecem educação infantil.

\subsection{JUSTIFICATIVA}

Nas últimas décadas a internet proporcionou transformações no modo de comunicação dos indivíduos propiciando várias mudanças na sociedade.

As crianças hoje nascem imersas no mundo tecnológico. Pesquisas sobre a utilização de Tecnologia da Informação e Comunicação (TIC) no país são realizadas, o TIC Crianças. Em 2010 o Centro de Estudos sobre as Tecnologias da Informação e da Comunicação (Cetic.br), por meio do Comitê Gestor da Internet no Brasil (CGI.br), inicia as pesquisas sobre crianças nascidas no período de 2001 e 2005. Em 2013 o TIC Crianças foi incorporado ao escopo do TIC Domicílios. Entretanto, os dados distintos relativos a faixa etária dos 5 aos 9 após o TIC Crianças 2010 não foram publicados na edição do TIC Domicílios em 2013.

Profissionais da área de tecnologia de informação estão preocupados com as interfaces infantis, porém, para fins comerciais. Jakob Nielsen (2010), um dos principais especialistas em usabilidade na web, no relatório do estudo intitulado "Usability of websites for children" com crianças entre três e doze anos, afirma que esses usuários estão precocemente expostos às mídias e a internet. $\mathrm{O}$ autor aborda alguns pontos a serem considerados no ambiente digital voltado para crianças, como o fato dessas utilizarem o mesmo método de navegação. Ou seja, caso a interface do site de um jogo mesmo seja difícil de acessar a criança provavelmente não retornará ao jogo ou site.

Estudos do comportamento de usuários, assim como a necessidade informacional e usos, são categorias de estudo da Cl apontadas por Borko (1968). Estudar o comportamento, uso e a interação decorrente do processo de utilização das TIC's, assim como identificar as estratégias de comunicação da informação utilizadas na escola para e pelas crianças é imprescindível na ciência da informação, pois, utilizam e recebem diversos tipos de informações.

Le Coadic (2004, p.5) versa sobre o conceito de informação e documento sendo conhecimento registrado em diversos suportes. Baseando-se nisso, a criança 
utiliza diversos tipos de informação em variados suportes, grande parte no formato digital.

No entanto, o trabalho aqui proposto não tem como objetivo emitir opinião a respeito das consequências do uso de aparelhos tecnológicos pelas crianças da primeira infância. Por considerar que deveria haver estudo aprofundado e por período de tempo maior para verificar seriamente esse tema. Esta pesquisa pressupõe a utilização de instrumentos tecnológicos para acessarem informação digital na escola e considera as crianças como usuárias e receptoras potenciais de informação.

De acordo com Piaget (1999), as experiências decorrentes da interação da criança com o meio influenciam de modo significante o seu desenvolvimento. Quando a criança joga, escuta música, assiste filme, "lê" um livro, faz uso da informação. E durante esse uso ocorre a comunicação e mediação da informação. Logo a relevância em saber: Quais as estratégias de comunicação e mediação entre a criança da primeira infância e a informação digital no âmbito escolar?

\subsection{OBJETIVOS}

Nesse sentido o objetivo geral do presente relato é identificar estratégias de comunicação e mediação entre a criança da primeira infância e a informação digital na educação infantil.

São objetivos específicos (OE):

OE1: Caracterizar a informação digital para as crianças da primeira infância no ambiente escolar.

OE2: Descrever a interação das crianças com a informação digital no contexto escolar e as estratégias de comunicação e mediação da informação entre as crianças da primeira infância e a informação digital.

OE3: Propor modelo de estratégia de comunicação e mediação da informação entre as crianças da primeira infância e a informação digital. 


\title{
2 REVISÃO DE LITERATURA
}

A revisão de literatura pretende, por meio de pesquisa bibliográfica, reunir referências relacionadas ao assunto de pesquisa. Primeiramente, abordou a comunicação e mediação da informação, assim como suas estratégias considerando a criança da primeira infância como protagonista. Em seguida, um tópico geral sobre infância, criança, educação e tecnologia. Logo após, é apresentada a informação digital na educação infantil e, na sequência a interação humano computador.

\subsection{INFÂNCIA, CRIANÇA, EDUCAÇÃO E TECNOLOGIA}

As diretrizes curriculares nacionais para educação infantil trazem a seguinte definição para o termo criança:

\begin{abstract}
sujeito histórico e de direitos que, nas interações, relações e práticas cotidianas que vivencia, constrói sua identidade pessoal e coletiva, brinca, imagina, fantasia, deseja, aprende, observa, experimenta, narra, questiona e constrói sentidos sobre a natureza e a sociedade, produzindo cultura. (MINISTÉRIO DA EDUCAÇÃO E CULTURA, 2010)
\end{abstract}

Para compreender melhor a evolução da criança na sociedade, é necessário entender a visão em diferentes momentos históricos sobre este pequeno indivíduo.

$\mathrm{Na}$ era medieval, enxergava-se a criança de outra maneira, como mini adultos, segundo Ariès (2006, p.17). Por meio de imagens e relatos da época, o autor investigou como os pequenos eram expostos e retratados nas pinturas. Antes da Idade Média não se constatou indícios de infância. Observou-se nas fotografias como as crianças eram descritas, suas roupas, se estavam acompanhadas com sua família ou com outros adultos, porém sempre representando atividade adulta.

A partir do século XVIII, a criança deixa de ser vista como adulto. A sociedade passa compreender a distinção e as peculiaridades entre crianças e adultos, originando o sentimento de infância.

O termo infância tem origem da palavra infantia, significa "dificuldade ou incapacidade de falar; criança (indivíduo na infância, criação) é o que é novo. A infância é símbolo de simplicidade natural, de espontaneidade" (FRIEDMANN, 2005, p.17). 
À medida que ocorrem transformações na visão da sociedade sobre infância e criança, notam-se mudanças na educação de modo geral. Na educação, por exemplo, quando se cria a educação infantil consideram os períodos pertinentes a cada fase vivida pela criança. Pensadores e filósofos ao longo da história contribuíram para que se conhecesse a atual visão de infância, educação e sociedade. A seguir (quadro 1) alguns deles e seus principais legados:

Quadro 1 Pensadores e suas contribuições educação, sociedade e concepção da infância (LAGAR, et al., 2012)

\begin{tabular}{|c|c|}
\hline Período & Legado para Educação/Sociedade \\
\hline (469-399 a.C.) & $\begin{array}{l}\text { Estímulo das ideias, impulsionando a } \\
\text { busca pela verdade, pensamento interior }\end{array}$ \\
\hline (427-347 a.C.) & $\begin{array}{l}\text { Desenvolveu sistema educacional e } \\
\text { incluiu ética e política. Educação vista } \\
\text { como papel imprescindível na } \\
\text { reorganização da sociedade. }\end{array}$ \\
\hline (382-322 a. C.) & $\begin{array}{l}\text { Argumentava que a responsabilidade da } \\
\text { educação é do Estado. Defendia } \\
\text { aprendizagem }\end{array}$ \\
\hline$(1562-1670)$ & $\begin{array}{l}\text { Defendeu o ensino de tudo para todos e } \\
\text { foi o primeiro a considerar a inteligência } \\
\text { e o sentimento da criança. Preconizava } \\
\text { aplicação de métodos que despertasse } \\
\text { o interesse do estudante. }\end{array}$ \\
\hline$(1632-1704)$ & $\begin{array}{l}\text { Pregava que o professor deveria } \\
\text { preencher o cérebro das crianças com } \\
\text { informações e vivências. "O aprendizado } \\
\text { de fora para dentro", porém considerava } \\
\text { a individualidade na capacidade do } \\
\text { entendimento. }\end{array}$ \\
\hline Johann H. Pestalozzi $\quad(1746-1827)$ & $\begin{array}{l}\text { Aprendizagem autônoma despertada } \\
\text { pela criança por meio dos seus } \\
\text { sentimentos. O objetivo do ensino era o } \\
\text { auxiliar a criança no desenvolvimento de } \\
\text { suas habilidades naturais e inatas. }\end{array}$ \\
\hline Friedrich Froebel & $\begin{array}{l}\text { Criou o jardim infância. Considerava a } \\
\text { infância como parte da vida importante } \\
\text { para formação do adulto. Precursor da } \\
\text { ideia de que brincar não é apenas } \\
\text { diversão e sim o início da aprendizagem } \\
\text { e uma das formas de representar o } \\
\text { mundo real com propósito de entendê- } \\
\text { lo. Acreditava na educação espontânea. }\end{array}$ \\
\hline
\end{tabular}




\begin{tabular}{|l|l|l|}
\hline John Dewey & (1859-1952) & $\begin{array}{l}\text { Alegava que para maturidade emocional } \\
\text { e intelectual da criança seria necessário } \\
\text { como recursos a democracia e a } \\
\text { liberdade. Teoria de Dewey tinha como } \\
\text { meta educar a criança físico, emocional } \\
\text { e intelectual. Julgava que teoria e prática } \\
\text { deveriam caminhar juntas. Acreditava } \\
\text { que trocar ideias, experiências sobre } \\
\text { suas vivências as crianças teriam um } \\
\text { processo educativo efetivo. }\end{array}$ \\
\hline Maria Montessori & $(\mathbf{1 8 7 0 - 1 9 5 2 )}$ & $\begin{array}{l}\text { Considerava o potencial do aluno, na } \\
\text { autoeducação. }\end{array}$ \\
\hline Jean-Ovide Decroly & $(\mathbf{1 8 7 1 - 1 9 3 2 )}$ & $\begin{array}{l}\text { Educação a partir das necessidades das } \\
\text { crianças. A escola prepara a criança } \\
\text { para o convívio em sociedade. }\end{array}$ \\
\hline Célestin Freinet & $(\mathbf{1 8 9 6 - 1 9 6 6 )}$ & $\begin{array}{l}\text { ldealizou a escola moderna e } \\
\text { democrática. Pregava que o dever da } \\
\text { escolar é formar cidadãos. } \\
\text { aprendizagem se dá por meio de teoria } \\
\text { e prática. }\end{array}$ \\
\hline
\end{tabular}

Fonte: Elaboração própria

A evolução nos estudos da área de educação e comportamento humano reflete a mudança da percepção da criança conforme visualizado no quadro 1. A criança passa a ser percebida como indivíduo cheio de peculiaridades inerentes a sua idade e visão de mundo. Os estudiosos consideram a "concepção de criança com base na cultura, na história e no social (...)" ligado intrinsecamente aos "fatores desencadeantes [motivações, trocas, interesses e descobertas quando pelo menos duas crianças interagem] presentes nas relações sociais das crianças" (POZAS, 2011, p. 31). As brincadeiras e os jogos podem ser considerados alguns desses fatores, "teóricos são unânimes ao afirmar que, por meio da brincadeira e do jogo, a criança se desenvolve, relaciona-se e constrói seu conhecimento" (POZAS, 2011, p. $31-32)$.

Anteriormente ao século XIX a criança era desvalorizada. Após Locke, por volta de 1705 , surge a nova concepção de criança em que consideram os seus comportamentos naturais e o seu grande potencial interior.

Pozas expõe a criação de Froebel, “Kindergarden”, baseado em brincadeiras utilizadas como suporte pedagógico. Afirma ainda que "para ele [Froebel], brincar é 
uma atividade inata, e brincadeira é uma ação metafórica, livre e espontânea da criança", há consagração do "principal meio de educação da criança pequena, mascarando [...] toda a dimensão cultural e social" (POZAS, 2011, p.34). Ilustrando existência da valorização e visão da dimensão lúdica inerente a criança e como fonte de aprendizagem.

A criança cresce interagindo com o mundo acumulando experiências e, aos poucos, moldam sua personalidade, seu conhecimento e inteligência. $O$ adulto é $O$ resultado desta equação entre acúmulo de experiências e interações vivenciadas desde início até o final de sua vida.

Para se entender melhor a criança, é relevante explanar como se dá o desenvolvimento cognitivo e emocional.

Quando a criança nasce, seu sistema nervoso passa apresentar um crescimento exponencial das redes neurais que torna possível aprender a andar, falar e guardar memórias. Entre os 3 e 6 anos essas redes crescem mais, se tornando possível o planejamento de raciocínio (MYERS, 2014).

Jean William Fritz Piaget (1896-1980) se consagrou devido aos estudos sobre desenvolvimento da inteligência humana. Piaget estudou os próprios filhos com intuito de compreender a evolução do conhecimento humano (WADSWORTH, 1995).

Piaget divide a construção do conhecimento humano em quatro estágios, conforme quadro 2 . 
Quadro 2 Estágios do desenvolvimento cognitivo de acordo com Piaget

\begin{tabular}{|c|c|c|}
\hline \multicolumn{3}{|c|}{ Estágios do desenvolvimento cognitivo de acordo com Piaget } \\
\hline Faixa etária & Descrição do estágio & $\begin{array}{l}\text { Fenômenos do } \\
\text { desenvolvimento }\end{array}$ \\
\hline $\begin{array}{l}\text { Nascimento até } 2 \\
\text { anos }\end{array}$ & $\begin{array}{l}\text { Sensório-motor (vivência } \\
\text { do mundo por meio das } \\
\text { ações e sentidos) }\end{array}$ & $\begin{array}{l}\text { Permanência no objeto; } \\
\text { ansiedade diante do } \\
\text { desconhecido. }\end{array}$ \\
\hline De 2 aos 6 anos & $\begin{array}{l}\text { Pré-Operacional } \\
\text { (representação das coisas } \\
\text { com imagens e palavras; } \\
\text { usa a intuição). }\end{array}$ & $\begin{array}{l}\text { Brincadeiras de faz de conta e } \\
\text { egocentrismo. }\end{array}$ \\
\hline De 7 aos 11 anos & $\begin{array}{l}\text { Operacional concreto } \\
\text { (pensamento lógico sobre } \\
\text { eventos concretos; } \\
\text { entende analogias } \\
\text { concretas e efetua } \\
\text { operações aritméticas.) }\end{array}$ & Transformações matemáticas \\
\hline $\begin{array}{l}\text { Por volta dos } 12 \\
\text { anos }\end{array}$ & Raciocínio abstrato & $\begin{array}{l}\text { Lógica abstrata; potencial para } \\
\text { raciocínio moral. }\end{array}$ \\
\hline
\end{tabular}

Fonte: Myers, (2014, p. 137)

Importante salientar que nos estágios ou estádios elencados por Piaget, as idades são utilizadas como referência, nada impede que uma criança de 7 anos, por exemplo, esteja no pré-operacional e uma de 6 esteja no operacional concreto.

O primeiro estágio definido por Piaget é o sensório-motor - compreende crianças desde o nascimento até aproximadamente dois anos - caracteriza-se pela assimilação motora, reflexos e início das emoções, prioriza as ações e percepções. Nesse período, a criança se torna apta de utilizar o que a literatura chama de inteligência prática ou sensório motor. Os pequenos são capazes de realizar e aprender novas habilidades como andar e sentar. No decorrer desse período, a criança começa a se diferenciar do mundo, pois anteriormente, o que tinha significado para ela era o seu corpo. Essa diferenciação ou percepção ocorre no lado afetivo. Quando ocorrem os primeiros sentimentos, como medo (BOCK, et al, 2008; MYERS, 2014).

O segundo é o estágio pré-operacional, no qual estão inseridas crianças entre 2 e 7 anos. Fase dominada pelo egocentrismo, maior desenvolvimento da linguagem 
e o simbolismo. Nessa etapa acontece também o aparecimento da representação, marcando o término do estágio sensório motor. Ocorre a mudança do estágio sensório-motor, em que havia o predomínio da inteligência motora, para o pensar devido à socialização e a utilização da linguagem pelas crianças.

A utilização da linguagem resulta na aceleração do desenvolvimento do pensamento e suas consequências mais evidentes, de acordo com Bock et. al. (2008), é a interação e a comunicação entre os seres humanos.

Piaget, de acordo com Wadsworth (1995), elenca, respectivamente, as formas de representação como ocorrem na criança, são eles: imitação diferida, jogo simbólico, desenho, imagem mental e como exposto anteriormente a linguagem falada.

A imitação diferida consiste em imitar objetos e eventos vividos há um tempo com pessoas próximas da criança. A imitação diferida é relevante, pois mostra que a criança desenvolveu a capacidade de recordar o comportamento imitado.

O jogo simbólico é a construção de símbolos que representam algo. É um jogo de faz de conta. A finalidade do jogo simbólico é transformar o objeto real em um desejado. Por exemplo, quando um garoto usa uma caixa como carrinho.

Quanto ao desenho, começam a desenhar, não possuem a intenção de representar algo. Porém, alguns desenhos podem parecer com alguma forma. No decorrer do período pré-operacional as crianças passam a representar coisas com seus desenhos.

As imagens mentais são representações internas de momentos vivenciados pelos pequenos, embora não sejam tão fieis à realidade.

Aproximadamente com 2 anos, a criança começa a falar uma palavra. Logo após, ela expande sua capacidade verbal e, quando alcança os quatro anos, possui domínio maior da linguagem, considerando algumas regras gramaticais simples e entende o que escuta (WADSWORTH, 1995).

O terceiro estágio proposto por Piaget denomina-se operatório completo ou concreto, compreendido por crianças entre 7 a 11 anos. Destaca-se pela capacidade das crianças relacionarem e atribuírem valores, interagindo com objetos e situações reais. Bock et al. (2008) elenca atividades que a criança pode executar a nível de pensamento. São elas: "estabelecer corretamente as relações de causa e efeito e de meio e fim; sequenciar ideias ou eventos; trabalhar com ideias sob dois pontos de vista, simultaneamente". 
O quarto estágio é denominado por Piaget de operatório formal ou operações formais. Abarca adolescência que acontece aproximadamente com 11 ou 12 anos em diante. Apresentação do pensamento hipotético, capacidade de tirar suas próprias conclusões.

Outro teórico relevante quando o assunto é desenvolvimento cognitivo humano é Lev Semenovitch Vygotsky (1896-1934). Consagrou-se por estudar as interações sociais vividas pelas crianças $e$ as suas influências no seu desenvolvimento intelectual.

Vygotsky considera o pensamento da criança autônomo e capaz de associar suas ações à representação do mundo, considerando o aspecto cultural. Na escola, por exemplo, vivenciam o ensino-aprendizagem em que se percebe claramente a interação entre os elementos envolvidos neste processo.

A capacidade da criança em resolver problemas e criar inúmeras possibilidades a partir desta resolução com ajuda de outras pessoas é chamada de Zona de Desenvolvimento Proximal (ZDP). Vygotsky (1998, p. 112) expõe a seguinte definição para ZDP

\begin{abstract}
a distância entre o nível de desenvolvimento real, que se costuma determinar através da solução independente de problemas, e o nível de desenvolvimento potencial, determinado através da solução de problemas sob a orientação de um adulto ou em colaboração com companheiros mais capazes.
\end{abstract}

No âmbito escolar, o professor favorece a aprendizagem e atua como mediador entre a criança e o mundo.

Após o advento do computador e a internet, o professor conta com mais ferramentas e possibilidades para realizar essa mediação. Além disso, os alunos chegam à escola com alguma base tecnológica, sociológica e cultural.

Ao longo de décadas, com o progresso tecnológico, surgiram várias nomenclaturas para designar as gerações de crianças e jovens da época correspondente. Classificações de gerações digitais, conforme descritas por Gabriel (2013, p. 85-95) são: Baby boomers (nascidos entre 1946 e 1964); Geração X (nascidos entre 1960 e 1980); Geração Y, Millennials, Generation Next e Echo Boormes (nascidos entre 1980 e 2000), Geração Z, iGeneration, Net Generation e Nativos digitais (nascidos após 2000) e ainda a Geração Polegar (Thumb 
Generation) definida por Howard Rheingold em 2003, se referindo ao modo dos jovens digitarem mensagens no celular utilizando apenas os polegares.

A expressão cunhada por Prensky (2001) "nativo digital" causa algumas interpretações equivocadas, devido à consideração de que o nativo digital domina todos os aparatos tecnológicos ou ainda assuntos correlatos. Nativo digital é aquele que nasce imerso à tecnologia, porém não significa que são experts e utilizam todas as tecnologias disponibilizadas a eles. Há os que têm aversão e dificuldade ao utilizarem aparatos tecnológicos. A despeito do emprego da expressão, Prensky em sua página na internet ${ }^{6}$ elucida que:

os nativos digitais / imigrantes digitais é uma metáfora, é a forma abreviada de expressar que muitas das atitudes formadas por aqueles que cresceram no antigo, choque cultural pré-digital com os dos nativos, cujas atitudes foram formados na nova cultura, arte digital isto é independente do que cada um pode "saber" sobre como funciona a tecnologia digital de. (PRENSKY, 2001)

Entretanto, as expressões nativos e imigrantes digitais não são sobre o que as pessoas sabem, ou podem fazer com a tecnologia. Todo mundo tem que aprender de uma forma ou de outra. É mais sobre a cultura e atitudes dessas gerações.

É notório que toda essa evolução da percepção do que é infância, as transformações das gerações high tech trouxeram grandes mudanças no modo de ensinar, aprender e de perceber a sociedade.

\subsection{COMUNICAÇÃO E MEDIAÇÃO DA INFORMAÇÃO E A CRIANÇA DA PRIMEIRA INFÂNCIA}

Comunicar-se é o ato essencial entre indivíduos para conviverem em sociedade. Por meio da comunicação, transmitem seus pensamentos, desejos, trocam experiências, há interação entre os elementos envolvidos. Pode ser entendida ainda como "processo de criação de significados entre duas ou mais pessoas" (TUBBS, MOSS, 2003, tradução do autor).

Existem diversas formas de comunicação. Berlo (2003, p.2-3) aponta várias delas como: a comunicação escrita; ilustrada; falada; por gesto; em grupo; em

\footnotetext{
${ }^{6}$ http://marcprensky.com/digital-native/
} 
massa; por ação; consigo; impressa; química; tato; símbolo; por sons; por cultura material; por figuras e pelas artes.

Para ilustrar os processos de comunicação, existem alguns modelos clássicos como os de Lasswell (1948), Shannon (1949), Ruesch e Bateson (1951), Osgood e Schramm (1954), Berlo (1960), Dance (1967), Tubbs (2003). Cada autor apresentou seu modelo em contextos e em épocas diferentes (ver figuras 4,5,6,7,8,9 e 10).

Modelo de Lasswell (1948) consiste em responder as cinco questões para delinear a comunicação de acordo com a figura 4.

Figura 4 Modelo de Lasswell.

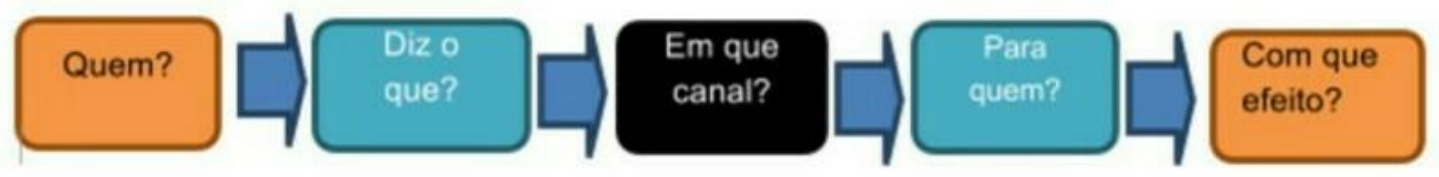

Fonte: MCQUAIL, D. ; WINDAHL, (1993). Ilustração própria.

O modelo de Shannon e Weaver (1949) (ver figura 5) considera como elementos de comunicação o emissor, mensagem, canal ou meio e o receptor. Os quatro elementos elencados por Shannon poderiam sofrer interferência na transmissão da mensagem, que seria a fonte de ruído. Uma característica relevante desse modelo é a falta de interação entre os envolvidos. A comunicação ocorre por meio da interação entre os envolvidos.

Figura 5 Modelo de Shannon e Weaver (1949).

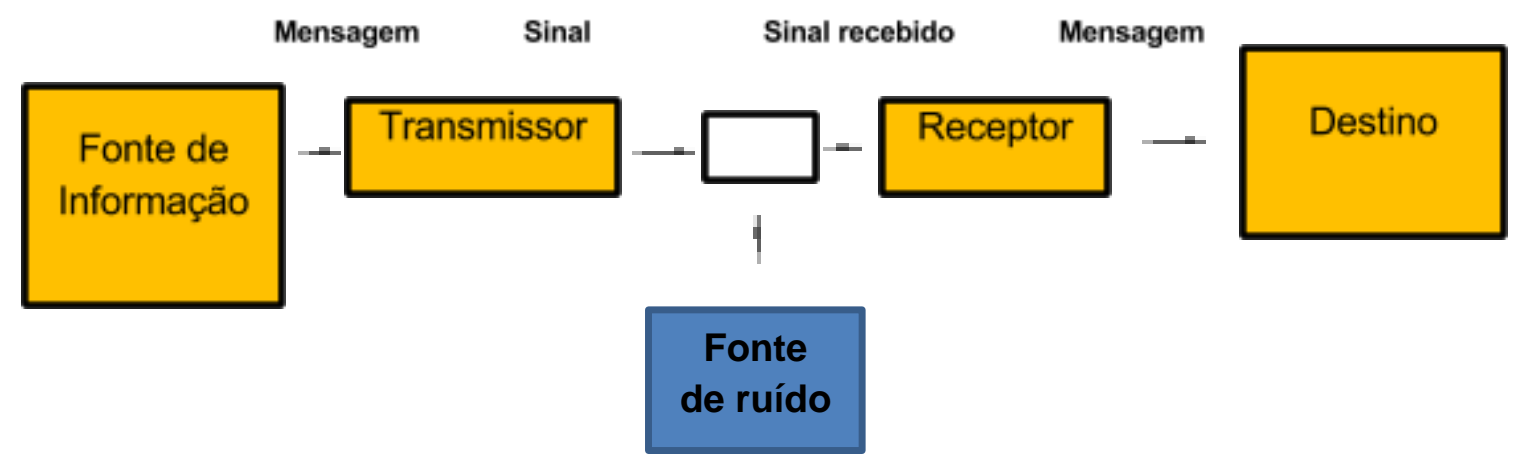

Fonte: MCQUAIL, D., WINDAHL, (1993). 
O modelo funcional (conferir figura 6), desenvolvido por Jurgen Ruesch e Gregory Bateson pontua que a informação age diretamente nas pessoas. $O$ processo acontece em quatro níveis, a saber: Recebendo a mensagem, canalizando, enviando e avaliando a informação. A respeito, Mendonça afirma que

a estrutura mantem em seu primeiro nível, o processo interpessoal; no segundo, os focos de troca de experiências entre dois participantes do processo (os quais entendemos como emissor e receptor); elementos de interação entre muitas pessoas no nível três; e ao nível quatro, o processo cultural em larga escala de troca entre os indivíduos. Esse exemplo não dá fim a todos os comportamentos comunicativos, porque o processo, aparentemente, se fecha em um ciclo onde as trocas de informação e conhecimento não extrapolam os limites. Em nosso entendimento, esse movimento limita a extensividade comunicacional, mas a figura a seguir ilustra como se dá o processo no contexto social da comunicação. (MENDONÇA, 2007, p.22)

Figura 6 Modelo Funcional de Ruesch e Bateson (1951).

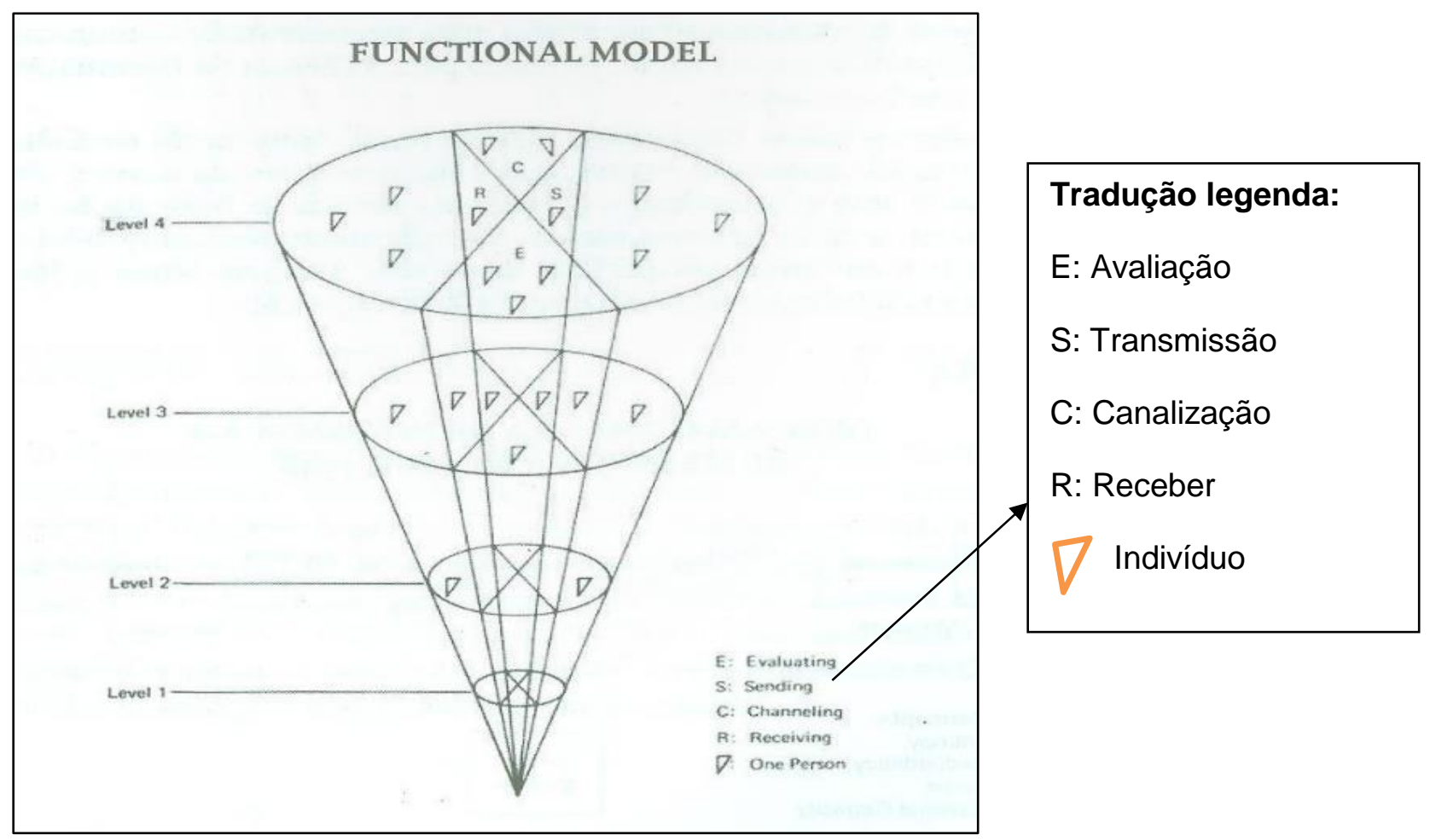

Fonte: MENDONÇA, 2007.

O modelo de Osgood e Schramm (1954), ver figura 7, seria o avanço do modelo de Shannon e Weaver, considerando a comunicação como um processo cíclico e acrescenta a fase de retroalimentação. 
Figura 7 Modelo Circular de Osgood e Shramm (1954).

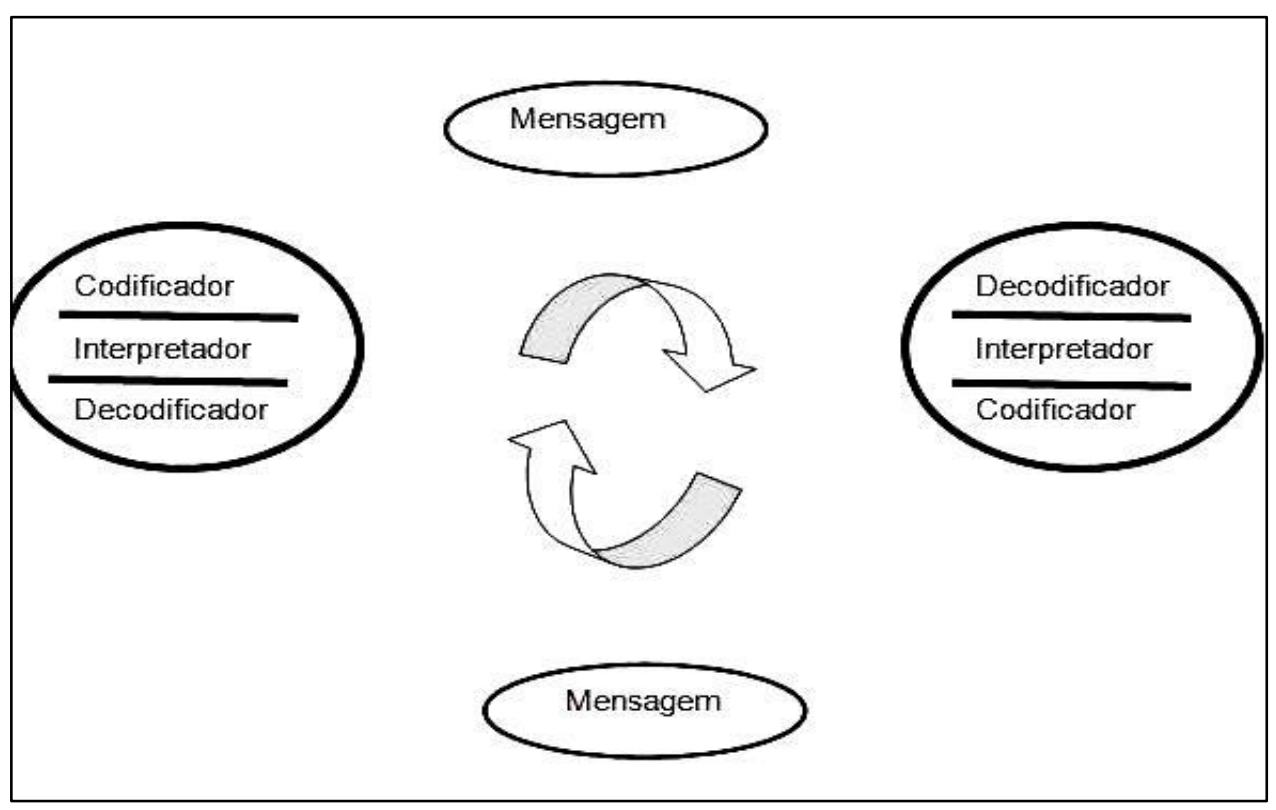

Fonte: MCQUAIL, D.; WINDAHL, S., 1993.

David K. Berlo dar por certo que comunicação é "o processo através do qual um indivíduo suscita uma resposta num outro indivíduo, ou seja, dirige um estímulo que visa favorecer uma alteração no receptor por forma a suscitar uma resposta".

No modelo criado por Berlo (verificar figura 8) apresenta-se os elementos da comunicação interagindo entre si e influenciando uns aos outros.

Figura 8 Modelo de comunicação de Berlo (1960).

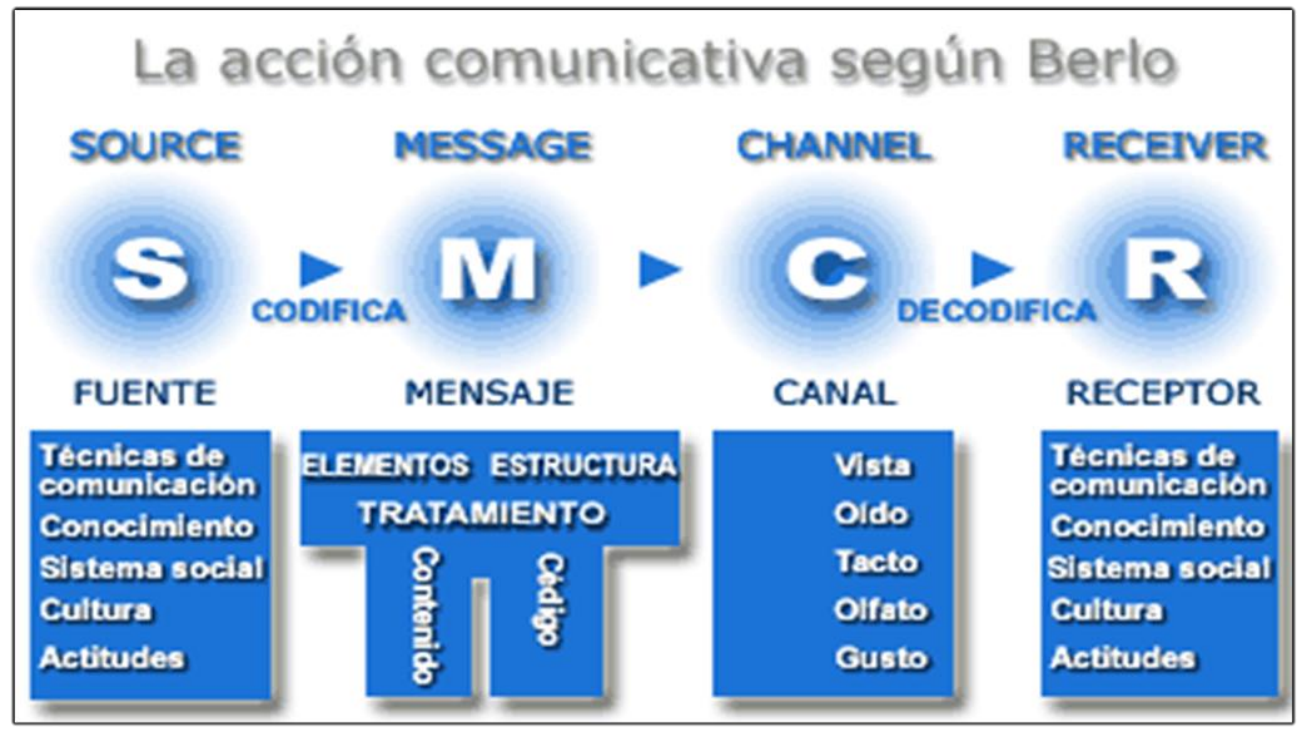

Fonte: MENDONÇA, 2007. 
Outro modelo clássico de comunicação é o de Dance (figura 9), baseado no modelo circular de Osgood e Shramm. Dance considerava a instabilidade dos elementos envolvidos no processo de comunicação e insere a variável tempo. Cada interação não se repete e ocorre em períodos diferentes. Do mesmo modo ocorrem com as experiências vividas pelos indivíduos desde o início até o fim da vida. Por mais que uma experiência se repita, terá algo de diferente da anterior. Analogamente, a interação ocorrida entre uma criança e o ambiente contribui para sua formação, como propõe Piaget.

Figura 9 Modelo helicoidal de Dance (1967).

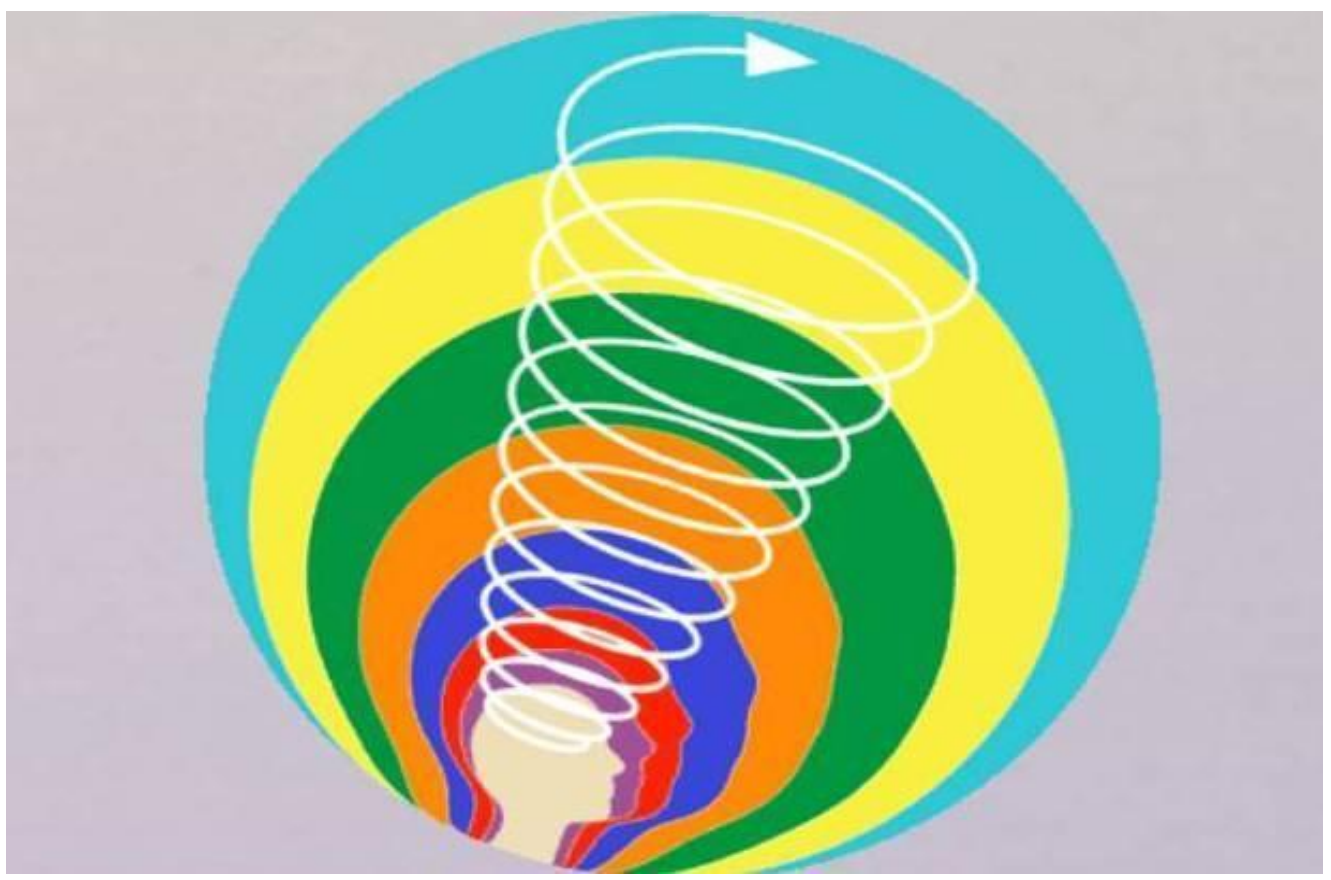

Fonte: CEBALLOS, 2014.

Tubbs apresentou em seu modelo de comunicação elementos que não existiam nos modelos anteriores. O modelo de comunicação de Tubbs (verificar figura 8) possui também natureza cíclica e mostra a presença fatores que interveem na interpretação da mensagem como interferências, feedback e filtros individuais (físicos e/ou psicológicos). 
Figura 10 Modelo de Tubbs (2003)

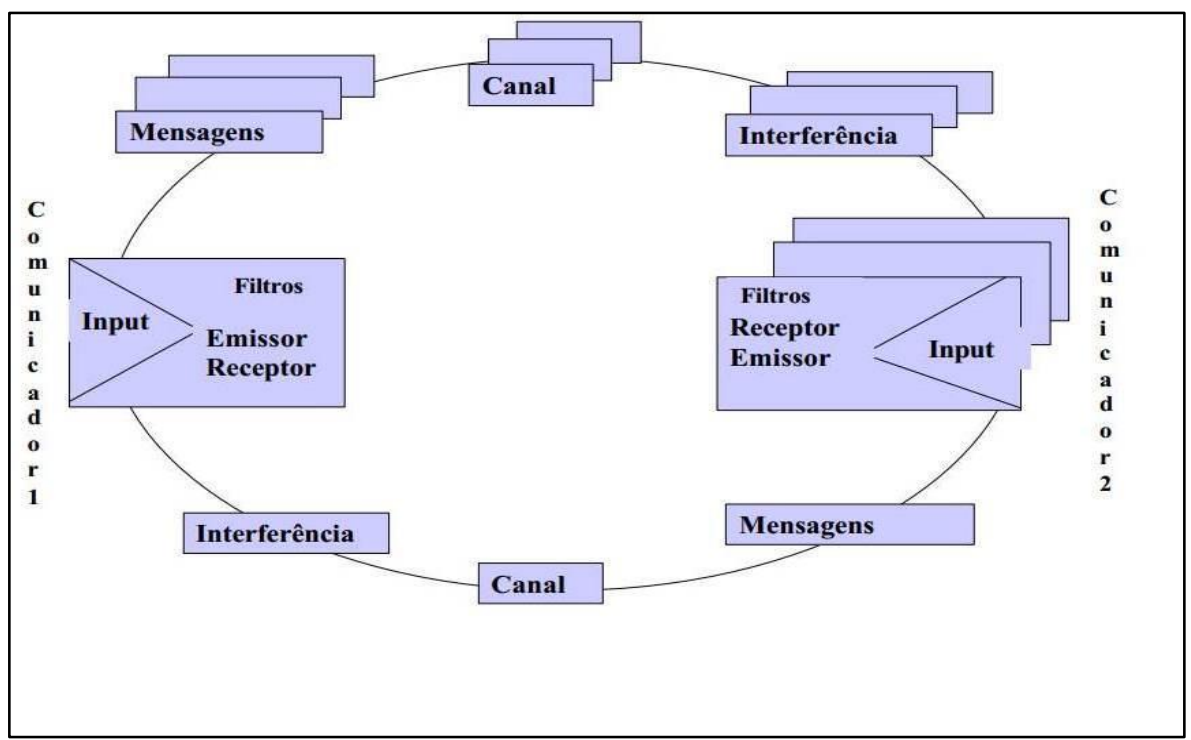

Fonte: MIRANDA, MENDONÇA, 2006.

Apesar das divergências entre tempo, é possível perceber que o modelo de Dance se assemelha com a ideia de desenvolvimento cognitivo infantil proposta por Jean Piaget (conferir figura 11).

Para relacionar os modelos de comunicação à criança se faz relevante abordar como acontece o desenvolvimento da comunicação infantil.

A comunicação infantil ocorre quando a criança ainda se encontra no útero da mãe, quando se movimenta à medida em que a futura mãe conversa com o feto. $O$ desenvolvimento da comunicação infantil acontece após o nascimento, quando o bebê chora a equipe médica entende que a priori está tudo bem.

No decorrer do seu desenvolvimento, a criança, interage com todos e tudo ao seu redor absorvendo o que a interação com meio pode proporcioná-la. O choro é a sua principal forma de comunicação e de sobrevivência até então, chora por dor, fome, sono e manhas. Em determinado momento ela percebe que se chorar mais alto a mãe atenderá o seu desejo mais rápido. Posteriormente, a criança, aponta o que deseja a chamada comunicação não verbal. Mousinho (2008) salienta que:

desde muito cedo já pode ser observada, como as variações do tônus (contração/descontração muscular) entre a mãe e o bebê, o olho no olho, as expressões faciais. $O$ apontar por volta dos 11 meses é um marco, podendo inicialmente ter a intenção apenas de "mandar" (apontar para algo que quer) e depois pode ter a intenção de compartilhar a atenção com alguém (apontar para que outra pessoa possa acompanhar aquele momento) 
De acordo com a divisão de Piaget citada por Seber (1991), a criança entre o nascimento aos dois anos se encontra no período sensório motor. Neste, a criança inicia os "primeiros esquemas vocais". Cada construção de som irá se fortalecer a medida que a criança o faz funcionar. Quando houver coordenação entre audição e fonação (produção fisiológica da voz), ou seja, quando ela passar a reproduzir o que ouvir. Esta combinação promove uma organização que interfere no reconhecimento do som e na sua produção do mesmo pela criança. Em consequência, quando ela escuta um "esquema vocal" que já tenha construído e por essa se sua referência a criança lhe atribui significado. O som também é assimilado pela audição e visão, "a criança começa a querer ver o que acabou de ouvir, ou seja, antecipa a existência de uma fonte sonora quando ocorre um som qualquer" (SEBER, 1991).

Por volta dos cinco meses, os pequenos começam a balbuciar. A família atribui significados aos sons que até então eram sem sentidos para criança. A soma de todas essas experiências relacionadas à comunicação faz a criança no decorrer do seu desenvolvimento se aprimorar cada vez mais. Após os dois anos ela será capaz de desenvolver uma conversa (MOUSINHO, 2008).

Pelo modo como as crianças se comunicam, alguns profissionais de educação e saúde são capazes de diagnosticar certas doenças, como o autismo.

O modelo de comunicação que se encaixa na situação descrita é o Helicoidal de Dance. A comunicação são processos que somados influenciaram a estrutura e o conteúdo da comunicação mais na frente. O autor afirma que a comunicação é de natureza dinâmica. A comunicação possui elementos, relações e ambiente que continuamente se transformam. O processo de comunicação, como todos os processos sociais, contém elementos, relações e ambientes que estão mudando continuamente. "A hélice descreve diferentes aspectos do processo de mudança ao longo do tempo" (DANCE apud MCQUAIL, WINDHAI, 1993). O autor aborda o seguinte exemplo: "Em uma conversa, o domínio cognitivo é cada vez maior para as partes ou atores envolvidos". Partindo desse exemplo à medida que a criança cresce interagindo com o mundo e as pessoas, ela aumenta sua capacidade de comunicação.

De acordo com as perspectivas da comunicação humana, a situação exposta se classifica como cultural e social, pois a comunicação das crianças sofre influências ambientais e culturais por toda a existência dela. 
Similarmente, Piaget defende que "o conhecimento é construído durante as interações da criança com o mundo" criando o modelo de estruturação cognitiva (conforme figura 11) analogamente ao modelo de comunicação de Dance. Piaget afirmava que a:

organização progressiva desde o seu início na criança recém-nascida, representando-a por meio de uma espiral com espiras que começam diminutas, mas que se alargam em função da subida, ou seja, o alargamento acompanha os progressos de inteligência (SEBER, 1991, p. 14).

Figura 11 Modelo espiral/helicoidal proposto por Piaget

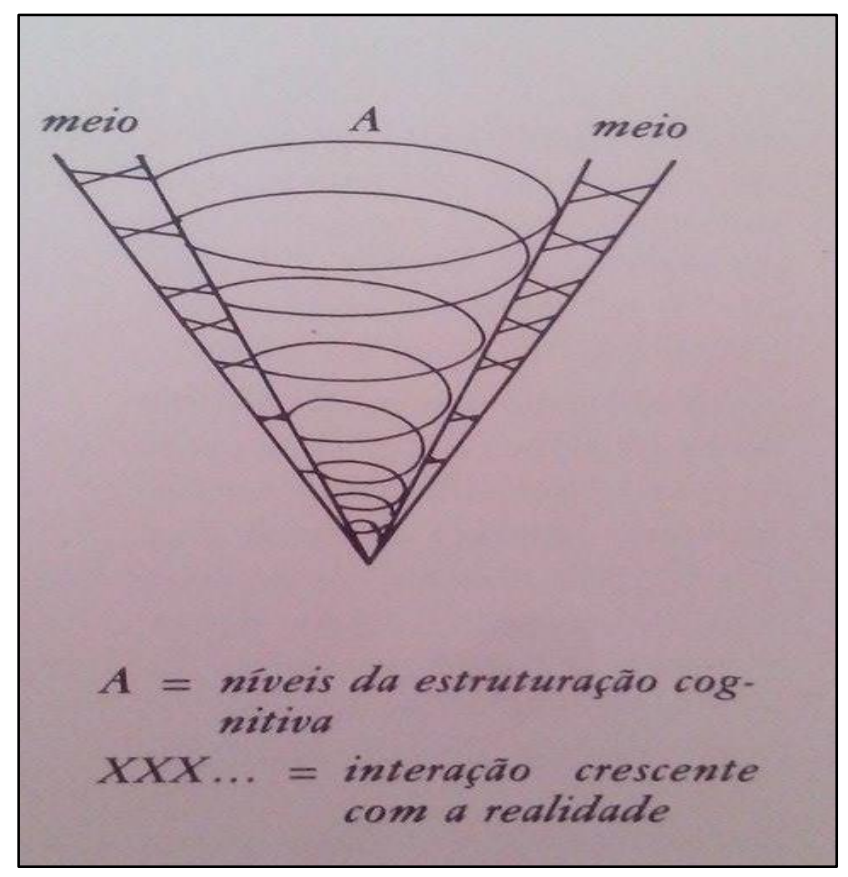

Fonte: (SEBER, 1991, p.15)

O modelo de níveis de estruturação cognitiva de Piaget mostra que, por meio da interação crescente entre indivíduo e realidade, há o aumento dos níveis da estrutura cognitiva. Ocorre por contínuas transformações nas estruturas cognitivas tendendo ao equilíbrio.

A teoria sóciointeracionista de Vygotsky (1998) elucida que o desenvolvimento dos indivíduos se dá pela troca de experiências com as pessoas e o meio através da interação e mediação. 


\subsection{MEDIAÇÃO DA INFORMAÇÃO}

O vocábulo mediar significa intervir acerca de, logo mediação é o ato de intermediar, de intervenção. Para a $\mathrm{Cl}$, pode ser entendida como processo de passagem que abarca 0 período de produção, disseminação, circulação e apoderamento da informação, minimizando a distância entre o emissor e receptor.

Mediação da informação é definida inicialmente por Almeida Junior (2009, p.92): "toda ação de interferência - realizada pelo profissional da informação -, consciente ou inconsciente; singular ou plural; individual ou coletiva; que propicia a apropriação de informação que satisfaça, plena ou parcialmente, uma necessidade informacional". O autor chegou a este conceito por meio de posicionamentos de profissionais da informação, que viam a mediação como um tipo de "ponte" que "permite a relação entre dois pontos que, de alguma forma, estão impedidos de interagir por obstáculos e empecilhos" (ALMEIDA JÚNIOR, 2009).

Com o uso das TIC's, o avanço tecnológico e o uso da internet, a comunicação da informação passa a ser instantânea. A internet passa ser protagonista no processo de mediação da informação. Os usuários não necessitam tanto do profissional da informação para ter acesso, basta que a interface do sitio que esteja a informação procurada atenda os critérios básicos de usabilidade. Porém, sempre haverá um profissional da informação na mediação, seja na fase de criação ou alimentação, ou ainda na fase final de disponibilização dessa informação. De acordo com Almeida Júnior (2009, p.92-93), há mediação implícita e explícita cuja as definições são:

mediação implícita, ocorre nos espaços dos equipamentos informacionais em que as ações são desenvolvidas sem a presença física e imediata dos usuários. Nesses espaços, como já observado, estão a seleção, o armazenamento e o processamento da informação. A mediação explícita, por seu lado, ocorre nos espaços em que a presença do usuário é inevitável, é condição sine qua non para sua existência, mesmo que tal presença não seja física, como por exemplo, nos acessos a distância em que não é solicitada a interferência concreta e presencial do profissional da informação.

Considerando o âmbito de desenvolvimento desta pesquisa e seus participantes, crianças entre 3 e 5 anos em aulas de informática, teríamos os dois tipos de mediações. As informações acessadas por elas são jogos em sua maioria, desenvolvidos por equipe especializada sem a presença do usuário e disponibilizada 
em rede, poderia ser exemplo de mediação implícita. Já a mediação explícita seria em sala de aula o professor, ou o responsável pelo laboratório como poderá ser verificado na análise de dados, atuam como mediadores da informação, selecionando e disponibilizando as informações digitais aos pequenos de acordo com sua idade ponderando sobre o conteúdo baseado nas diretrizes do MEC.

\subsection{ESTRATÉGIAS DE COMUNICAÇÃO E MEDIAÇÃO DA INFORMAÇÃO}

Quando se pensa em modos diferentes de propiciar aprendizado de novas competências e aquisição de conhecimentos que são decorrentes de experiências em sala de aula, fala-se de estratégia de ensino. Então, estratégia é o plano criado para alcançar algo ou alguma coisa.

A estratégia de comunicação pode ser definida como método empregado pelo emissor com o propósito de expor algo com significado. Os recursos estratégicos "são caracterizados devido à aplicação de mecanismos verbais e não verbais na transmissão informação longo do processo comunicativo" (FIGUEIREDO, 2003, p.178).

Toda exposição de conteúdo feita pelo professor é realizada por modos de comunicação, seja oralmente, por textos, imagens ou músicas. O aprender é um meio de recuperar essas informações.

No processo de comunicação em sala de aula, o professor é visto como mediador da informação está entre a informação comunicada e o seu destinatário, os alunos.

A interface no computador pode ser considerada como mediadora de informação, porém ela reproduz conteúdo criado e selecionado por um indivíduo. Logo, há mais elementos envolvidos no processo de comunicação e mediação da informação digital, como programadores, desenvolvedores, diagramadores, web designers, escritores, pedagogos, professores, dentre outros (ver quadro 3). 
Quadro 3 Relação ferramentas de comunicação e elementos envolvidos nesse processo de mediação da informação

\begin{tabular}{|l|l|}
\hline \multicolumn{1}{|c|}{ Ferramenta } & \multicolumn{1}{|c|}{ Elementos envolvidos } \\
\hline Jogos & $\begin{array}{l}\text { Equipe desenvolvedora do jogo; } \\
\text { mediadores (professores, ou outra } \\
\text { pessoa responsável em apresentar a } \\
\text { informação para criança ou ainda a } \\
\text { interface); o jogador }\end{array}$ \\
\hline Vídeos & Criador do vídeo, mediador, espectador \\
\hline Atividades em & $\begin{array}{l}\text { Autor da apresentação, mediador, e o } \\
\text { Power Point }\end{array}$ \\
\hline Buabio \\
\hline $\begin{array}{l}\text { Butores, ilustradores, desenvolvedores, } \\
\text { livros digitais }\end{array}$ & $\begin{array}{l}\text { bibliotecário (trabalha tanto como } \\
\text { mediador como fomentador e } \\
\text { selecionador da biblioteca digital) } \\
\text { mediadores, e leitores. }\end{array}$ \\
\hline
\end{tabular}

Fonte: elaboração própria.

O planejamento estratégico de como trabalhar conteúdos com as crianças traz melhores resultados para o aprendizado.

\subsection{INFORMAÇÃO DIGITAL NAS ESCOLAS DE EDUCAÇÃO INFANTIL}

Escopo da Cl, a informação, pode ser definida como "algo" com significado (BARRETO, 2001). Outra definição para informação é a de Yves-François Le Coadic (2004, p. 4-5)

informação é um conhecimento inscrito (gravado) sob a forma escrita (impressa ou numérica), oral ou audiovisual. A informação comporta um elemento de sentido. É um significado transmitido a um ser consciente por meio de uma mensagem inscrita em um suporte espacial-temporal: impresso, sinal elétrico, onda sonora, etc. essa inscrição é feita graças a um sistema de signos (a linguagem), signo este que é um elemento da linguagem que associa um significante a um significado: signo alfabético, palavra, sinal de pontuação.

A informação pode ser descrita, ainda, como dados organizados de modo compreensível registrado em papel ou outro meio suscetível de ser comunicado. Neste sentido, compreende-se que informação digital será a informação disponibilizada em suporte digital.

Como seria a informação na educação infantil? A informação para criança é aquela que está disponibilizada em diversos suportes e presente nas atividades em 
sala de aula, como por exemplo, os livros, desenhos, músicas, tarefas, vídeos, jogos todas as informações apresentam caráter lúdico.

Algumas instituições educacionais, como a Vivendo e Aprendendo, consideram impreterivelmente as opiniões e vontades das crianças com a participação ativa dos pais e da comunidade. A instituição foi criada em 1982 por pais que estavam descontentes com a situação e a forma de ensino no Distrito Federal. Denominada Associação Vivendo e Aprendendo. A escola acredita que o essencial para criança é o brincar (LAMEIRA, KAFURE, 2013).

A informação lúdica não está presente somente em instituições como a Vivendo e Aprendendo, mas também em instituições que utilizam como recurso pedagógico as TIC's. Pode ser denominada informação lúdica digital.

No tocante à tecnologia na educação, podem ser elencados três modos em relação ao seu uso. Primeiramente, o uso da tecnologia como fim remetendo a aprender a respeito de tecnologia; segundo, o usuário tem contato com a tecnologia para compreender, entender e dominar a tecnologia, aqui vista como meio; terceiro, a tecnologia utilizada por professores ou/e alunos para auxiliar nas aulas faz o papel de instrumento, ferramenta (PASSERINO, 2001). Considerando o contexto escolar infantil a utilização se baseia no terceiro modo. É utilizada para auxiliar o professor e ainda divertir as crianças.

No âmbito da escola de educação infantil, a presença de informação digital lúdica é apresentada em atividades executadas com sites de jogos como o friv, escola games, smartkids e demais sites de jogos, utilização de programa do pacote office do Microsoft como o power point e o paint, leitura de livros digitais, vídeos no youtube.

A escola trabalha de acordo com as diretrizes curriculares nacionais para educação infantil. A educação infantil é a primeira fase da educação básica ofertada em instituições educacionais públicas ou privadas com finalidade de educar e cuidar das crianças entre zero e cinco anos. De acordo com currículo (práticas que articulam "experiências e os saberes das crianças com os conhecimentos que fazem parte do patrimônio cultural, artístico, ambiental, científico e tecnológico, de modo a promover o desenvolvimento integral de crianças de 0 a 5 anos") e o Projeto Político Pedagógico - PPP (plano norteador que define objetivos para que sejam alcançados a aprendizagem e o desenvolvimento das crianças), que determinam o conteúdo e as atividades que serão trabalhadas com as crianças nos períodos de aulas. O PPP 
é elaborado pela direção, corpo docente e comunidade, e deve abarcar a garantia de acesso da criança aos "processos de apropriação, renovação e articulação de conhecimentos e aprendizagens de diferentes linguagens" e a "convivência e à interação com outras crianças" (MINISTÉRIO DA EDUCAÇÃO, 2010).

O currículo, de acordo com os parâmetros nacionais para educação infantil, é preparado considerando orientações em relação à interação, à brincadeira e à garantia de experiências que:

a) Promovam o conhecimento de si e do mundo por meio da ampliação de experiências sensoriais, expressivas, corporais que possibilitem movimentação ampla, expressão da individualidade e respeito pelos ritmos e desejos da criança;

b) Favoreçam a imersão das crianças nas diferentes linguagens e o progressivo domínio por elas de vários gêneros e formas de expressão: gestual, verbal, plástica, dramática e musical;

c) Possibilitem às crianças experiências de narrativas, de apreciação e interação com a linguagem oral e escrita, e convívio com diferentes suportes e gêneros textuais orais e escritos;

d) Recriem, em contextos significativos para as crianças, relações quantitativas, medidas, formas e orientações espaço temporais;

e) Ampliem a confiança e a participação das crianças nas atividades individuais e coletivas;

f) Possibilitem situações de aprendizagem mediadas para a elaboração da autonomia das crianças nas ações de cuidado pessoal, auto-organização, saúde e bem-estar;

g) Possibilitem vivências éticas e estéticas com outras crianças e grupos culturais, que alarguem seus padrões de referência e de identidades no diálogo e conhecimento da diversidade;

h) Incentivem a curiosidade, a exploração, o encantamento, o questionamento, a indagação e o conhecimento das crianças em relação ao mundo físico e social, ao tempo e à natureza;

i) Promovam o relacionamento e a interação das crianças com diversificadas manifestações de música, artes plásticas e gráficas, cinema, fotografia, dança, teatro, poesia e literatura; 
j) Promovam a interação, o cuidado, a preservação e o conhecimento da biodiversidade e da sustentabilidade da vida na Terra, assim como o não desperdício dos recursos naturais;

k) Propiciem a interação e o conhecimento pelas crianças das manifestações e tradições culturais brasileiras;

I) Possibilitem a utilização de gravadores, projetores, computadores, máquinas fotográficas, e outros recursos tecnológicos e midiáticos. (MINISTÉRIO DA EDUCAÇÃO, 2010)

Consoante às informações apresentadas até aqui, observa-se a constante interação da criança com diversas informações, em diversos formatos, além da interação social e ainda a preocupação do governo e sociedade.

A informação digital se faz presente nas escolas em sua maioria por jogos e vídeos. Especialistas em educação ${ }^{7}$ como a professora da Faculdade de Educação da Universidade Federal de Juiz de Fora (UFJF), Adriana Bruno; a professora da Faculdade de Educação da PUC-RS, Helena Cortês; o diretor de ensino do Instituto Federal de Educação, Ciência e Tecnologia do Triângulo Mineiro (IFTM), Humberto Estevam; o doutor em Educação pela PUC-SP, João Luís de Almeida Machado, doutor em Educação pela PUC-SP; a Maria Ângela Barbato Carneiro, professora da Faculdade de Educação da PUC-SP e a especialista em Tecnologias Interativas Aplicadas à Educação e professora de Informática do Colégio Santa Marcelina, em São Paulo, Melina Veiga, selecionaram alguns sites com atividades digitais para crianças. Os principais estão elencados com seus respectivos links e descrições:

a) Atividades educativas ${ }^{8}$

O site possui várias atividades educativas focadas para crianças e adolescentes. Aborda assuntos diversos para faixas etárias distintas. Sua interface é um pouco complexa para crianças menores de 6 anos.

b) Cocoricó $^{9}$

Site criando pela TV Cultura, baseado na série de mesmo nome. Disponibiliza desenhos para pintar, quebra-cabeças e jogos. Possui interface simples.

\footnotetext{
${ }^{7}$ Informações disponíveis no http://educarparacrescer.abril.com.br/comportamento/sites-educativos504552.shtml

${ }^{8} \mathrm{http}: / /$ www.atividadeseducativas.com.br/

${ }^{9} \mathrm{http}: / / \mathrm{cm}$ ais.com.br/cocorico
} 
C) Discovery kids ${ }^{10}$

É o site do canal de TV Discovery Kids dar acesso a diversos jogos, vídeos e atividades. Disponibiliza artigos e propostas para os pais trabalharem com as crianças.

d) Ecokids ${ }^{11}$

O website mostra dicas e jogos que ensinam preservar a natureza.

A interface é indicada para crianças que sabem ler ou acompanhadas por um adulto.

e) Educação Infantil ${ }^{12}$

O sítio deixa acessíveis os jogos para fins educativos, categorizados por assuntos como o alfabeto, coordenação motora, jogo dos erros, matemática, etc.

f) Escola Games ${ }^{13}$

Site desenvolvido com apoio pedagógico para crianças entre 5 e 9 anos. Jogos temáticos de língua portuguesa, matemática, geografia, história, ciências e língua inglesa.

g) Jogos educativos ${ }^{14}$

Compreende jogos infantis com propósitos educativos implícitos, fazem uso de cores e os jogos trabalham o raciocínio lógico.

h) Senninha ${ }^{15}$

Site criado em homenagem a Ayrton Senna, dispõe de passatempos jogos e vídeos.

i) TV Rá Tim Bum ${ }^{16}$

Pertence a TV Cultura, disponibiliza atividades interativas baseadas nos programas infantis, vídeos, jogos, imagens e programas de rádio.

O desenvolvimento de atividades com jogos selecionados pelos educadores ou responsáveis atraí à atenção das crianças e as ajudam fixarem os conteúdos. Além, de propiciar momentos divertidos.

\footnotetext{
${ }^{10}$ http://discoverykidsbrasil.uol.com.br/?cc=BR

${ }^{11} \mathrm{http} / / /$ www2.uol.com.br/ecokids/index.htm

${ }^{12} \mathrm{http}: / /$ www.edinfjogos.universoneo.com.br/

$13 \mathrm{http}: / /$ www.escolagames.com.br/

14 http://jogoseducativos.jogosja.com/

${ }^{15} \mathrm{http}: / /$ senna.globo.com/senninha/index.asp

${ }^{16}$ http://tvratimbum.cmais.com.br/
} 


\subsection{FATOR EMOCIONAL E COMPORTAMENTAL NA INTERAÇÃO ENTRE A CRIANÇA E A INFORMAÇÃO DIGITAL}

As diretrizes curriculares do MEC para educação infantil evoca a importância da criança brincar, trabalhar em grupo, comunicar-se, entender e compreender seus sentimentos e emoções.

Para discorrer a respeito do fator emocional no desenvolvimento infantil é relevante abordar o conceito de emoção, pois está intrínseca, ao desenvolvimento psicológico e cognitivo humano, além da ligação óbvia com fator emocional.

Algumas pessoas se emocionam ao assistirem cenas de filmes românticos ou cai na gargalhada vendo comédias, por exemplo. Esses sentimentos são respostas do corpo aos estímulos externos. Emoção é a "resposta de todo o organismo que envolve excitação fisiológica, comportamentos expressivos e experiência consciente" (MYERS, 2014, p. 378). "A palavra emoção se refere à percepção consciente de uma mudança específica no tom de sentimento interno". Essa percepção pode ser elencada por "um conjunto específico de mudanças físicas, pensamentos sobre o que está acontecendo e pensamentos sobre os eventos que produziram os sentimentos" (NEWCOMBE, 1999, p.156).

Qualifica-se emoção em humor, afeto e sensação. A emoção modifica as ideias. Del Nero ([2002], p.264) elucida que "a consciência é o palco das funções mentais. Nela ocorrem basicamente três grandes eventos: o pensamento, a emoção e a vontade".

As emoções não podem ser mensuradas diretamente, porém é possível observá-las pelas alterações fisiológicas como postura corporal e as expressões faciais, o movimento das sobrancelhas, a dilatação das pupilas e outras (BARROS, et al., 2008, p.36).

Nery (2003) em sua obra intitulada "Vínculo e afetividade: caminhos das relações humanas" no capítulo sobre a aprendizagem emocional, afirma que a matriz da identidade humana ocorre com a "primeira história de amor da vida da criança, que originará a aprendizagem das emoções". Os processos de interação da criança com o mundo e com as pessoas que ela aprende a diferenciar os sentimentos e com essa diferenciação a criança aprende valores, como ética social, moralidade e outras. 
Os relacionamentos interpessoais e a sua inerência na parte emocional são importantíssimos para a vida devido aos processos interativos que se moldam aos sistemas neurais que a organizam. "A deterioração nas relações interpessoais resultam em deterioração das relações sociais, das relações inter e intraorganizacionais" (LEITÃO, et al., 2006). Partindo desse princípio, as relações, a interação social é imprescindível na vida do ser humano desde nascimento.

O aprendizado se dá de forma distinta de acordo com a individualidade de cada criança ligada à parte emocional. A ciência cognitiva tem por objetivo levantar argumentos devidamente embasados a respeito da aprendizagem e sua ligação com o cérebro.

Por muito tempo, questões que cercam o indivíduo, como o funcionamento do cérebro, processo de aprendizagem e, vários estudos ao longo dos anos foram elaborados a fim de agrupar informações para fundamentar teorias que explicassem o processo de aprendizagem. Gardner (1996, p.19) considera as ciências cognitivas como: "um esforço, contemporâneo, com fundamentação empírica, para responder questões epistemológicas de longa data, principalmente àquelas relativas à natureza do conhecimento, se desenvolvimento e emprego".

Os cognitivistas afirmam que aprender é um processo de interação do individuo com o mundo externo e a organização disso no cérebro tem como consequência interna o conhecimento. O que for aprendido é mantido por "processos cerebrais como, como a atenção e a memória, que são integradores dos comportamentos cerebrais" (BOCK et al, 2008).

Para abordar este tema, é natural recorrer à psicologia com alguns de seus conceitos. Como o de comportamento que pode ser definido como interação entre pessoa e meio (BOCK et al, 2008). Nos estudos de comportamento não há como dissociá-lo do ambiente em que acontece.

Interagir significa "exercer ação mútua (com algo [e/ou alguém]), afetando ou influenciando o desenvolvimento ou a condição um do outro" ${ }^{17}$. A interação humano-computador (IHC) preocupa-se com o uso, a interação entre os usuários e os sistemas interativos intermediado pela interface.

O termo IHC nasce surgiu em 1980 para nomear área de estudos a respeito da interação entre usuários e computadores.

\footnotetext{
${ }^{17}$ Definição extraída do dicionário Houaiss. Disponível em: <www.houaiss.uol.com.br>
} 
A IHC é uma disciplina multidisciplinar que recorre à psicologia, sociologia, computação, ergonomia, design, linguística e Cl. Está reunida em cinco objetos de estudos: a natureza da interação - consiste em descobrir o que acontece durante a utilização dos sistemas interativos; o uso dos sistemas interativos dentro de um contexto - é a influência do contexto vivido pelo usuário na interação com sistema, já que, as pessoas estão inseridas em sociedade sofrendo interferências culturais. $O$ processo de interação envolve além do usuário, o sistema, o ambiente, o tempo, a finalidade do uso, de acordo com a figura 12.

Figura 12 elementos envolvidos no processo de interação

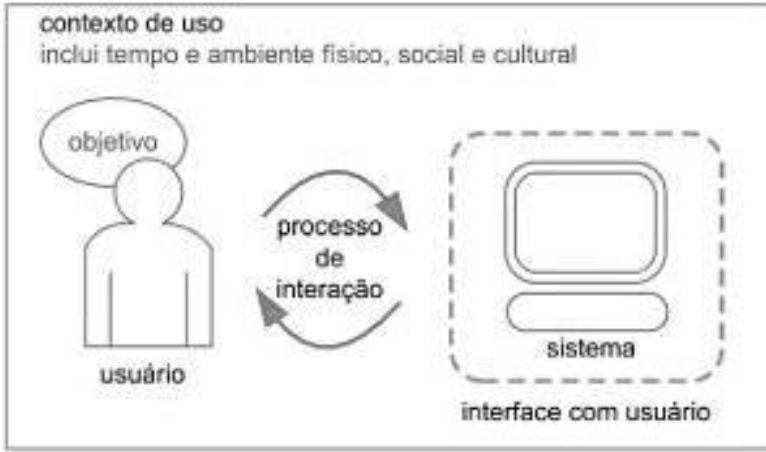

Fonte: BARBOSA; SILVA, 2011, p.18.

A IHC se torna viável por meio da tecnologia e, no mundo infantil, essa interação ocorre de forma lúdica por meio de uma interface, único meio de contato entre o usuário e um sistema interativo. De acordo com Kafure (2010, p.101) a qualidade da comunicação [interação] depende da adequação entre o modelo mental do usuário e a imagem do sistema.

Modelo mental é a representação de uma realidade gerada por um indivíduo considerando experiências vividas pelo mesmo e, a partir desse modelo, agir (ver figura 13). 
Figura 13 modelo mental apresentado por Kafure em sua tese em relação às necessidades e as expectativas dos usuários de Catálogo Público de acesso em Linha (OPAC) em bibliotecas

\begin{tabular}{|l|l|}
\hline \multicolumn{2}{|c|}{ Modelo Mental } \\
\hline Necessidades & - acesso à informaçăo \\
\hline Expectativas & $\begin{array}{l}\text { : localizar rapidamente a informaçăo procurada; } \\
\text { - uso fácil da imagem da IHC do OPAC. }\end{array}$ \\
\hline
\end{tabular}

Fonte: (KAFURE, 2004, p.4.)

O modelo mental apresentado por Kafure (2004, p.4) ilustra a ligação do modelo e as necessidades e expectativas do usuário de informação. Afirma que "apesar do progresso no domínio da concepção de interfaces para sistemas de informação, ainda existe discrepância entre a representação cognitiva que os usuários têm da tarefa e a representação computacional”. 


\section{METODOLOGIA DA PESQUISA}

A metodologia tem a finalidade de descrever as etapas de todo o processo de construção do trabalho. Com a intenção de alcançar o objetivo geral proposto nesta pesquisa, há relevância em discorrer sobre a metodologia e detalhar o tipo de pesquisa de acordo com alguns critérios defendidos em literatura, assim como o método utilizado.

Pesquisar consiste em indagar e encontrar ou não respostas. Conforme Cruz e Ribeiro (2003, p.11) pesquisar "é buscar compreender a forma como se processam os fenômenos observáveis, descrevendo sua estrutura e funcionamento". O processo de pesquisa vai além da atividade intelectual é conjunto de ações, sentimentos e pensamentos.

Metodologia, de acordo com Strauss e Corbin (2008), é o modo de pensar e estudar a respeito da realidade social.

Para compreender e alcançar os objetivos propostos neste trabalho recorreuse a abordagem de pesquisa qualitativa.

Pesquisa qualitativa, segundo Creswell (2010, p.26) é:

um meio para explorar e para entender o significado os indivíduos ou os grupos atribuem a um problema social ou humano. O processo de pesquisa envolve as questões e os procedimentos que emergem, os dados tipicamente coletados no ambiente do participante, a análise dos dados indutivamente construída a partir das particularidades para os temas gerais e as interpretações feitas pelo pesquisador acerca do significado dos dados.

O trabalho exposto classifica-se quanto aos objetivos como pesquisa exploratória e descritiva.

\subsection{UNIVERSO DE ESTUDO}

A pesquisa foi realizada em escolas de ensino infantil situadas no Distrito Federal. São elas:

a) Escola Ursinho Dourado em Santa Maria

b) Escola Franciscana Nossa Senhora de Fátima na Asa Sul

c) Colégio Santa Maria situado em Santa Maria

d) Colégio La Salle de Brasília localizado na Asa Sul 


\subsubsection{Participantes da pesquisa}

Os participantes do estudo são crianças entre 3 e 5 anos matriculados em escolas de educação infantil citadas no universo de estudo.

\subsection{PROCEDIMENTOS DE COLETA DE DADOS}

A revisão de literatura foi concretizada por meio de pesquisa documental em sites e revistas eletrônicas da área de Ciência da Informação, Educação, Tecnologia da Informação, Comunicação, Psicologia, além do Google e Google Acadêmico. Por buscas no catálogo da Biblioteca Central da Universidade de Brasília, na Biblioteca de Digital de Monografias da Universidade de Brasília, no Repositório Institucional da Universidade de Brasília, na Biblioteca Digital de Teses e Dissertações, Biblioteca Digital da Unicamp, Portal de Periódicos da Capes.

Para alcançar os objetivos deste trabalho utilizou-se da técnica de observação.

A coleta foi realizada por meio de observação assistemática ou não estruturada, que consiste em observar sem planejamento prévio e sem roteiro. A observação apresenta a vantagem de identificar conjunto de comportamentos. Pode ser assistemática, sistemática, não participante e participante. Neste trabalho utilizou-se da observação assistemática ou não estruturada, que tem por objetivo coletar e registrar informações reais sem que o pesquisador use outras técnicas e de acordo com Marconi e Lakatos (2011) é mais utilizada em pesquisa exploratória. A observação emprega os sentidos com atenção a um objeto de estudo com propósito de conhecê-lo em determinado contexto. Neste caso, várias crianças no âmbito escolar. Santos (2001, p.171-172) salienta que:

observar não é somente ver e ouvir, sem usar os estímulos da mente, pois esta informação não resultará em qualquer avanço em direção a um resultado que traga benefício à coletividade e traz compreensão das coisas e fatos a um nível individual muito restrito e sem profundidade. Contudo, a observação em nível científico não tem por fim acabar com a observação ocasional, espontânea ou vulgar, mas completá-la e melhorá-la, para que ela passe a ter validade. 
Durante o período de ingresso no Programa de Pós-Graduação até a elaboração do trabalho de pesquisa foram contatadas oito escolas em diversas cidades satélites do Distrito Federal, porém houve resistência por parte da maioria. Devido a peculiaridade dos sujeitos da pesquisa. Desta forma optou-se por omiti-las pelo fato de não haver relevância para pesquisa. Porém, duas instituições cederam espaço para realização da pesquisa e são elas: O Colégio Santa Maria (ver anexo 1) e o Colégio La Salle de Brasília (ver anexo 2).

Considerou-se como pré-teste observações realizadas em 2014 no Colégio Santa Maria e Colégio La Salle Brasília, dois breves estudos realizados respectivamente em 2012 na Escola Ursinho Dourado localizada em Santa Maria e em 2013 na Escola Franciscana Nossa Senhora de Fátima situada na Asa Sul, ambas cidades satélites do Distrito Federal.

As atividades no Ursinho Dourado e no Fátima consistiram na aplicação de questionário infantil para as crianças e observação delas durante atividade com a informação digital.

Segue as considerações a respeito de cada instituição sobre o uso e a comunicação e mediação da informação digital na educação infantil. 


\section{RESULTADOS E DISCUSSÃO}

Para esclarecer as relações entre o objeto de estudo e seus resultados. Neste tópico são apresentados os resultados e suas respectivas análises.

\subsection{ESCOLA URSINHO DOURADO}

A escola Ursinho Dourado fundada em 1995 em Santa Maria no Distrito Federal. Em 2012, estudavam na instituição 50 crianças matriculadas distribuídas nos turnos matutino e vespertino, divididas em três turmas em cada turno: maternal, jardim I e II. A principal missão da escola é oferecer condições adequadas para o bem-estar da criança e desenvolvimento integral; proporcionar à criança condições favoráveis à aquisição de conhecimentos; motivar a formação de hábitos saudáveis e promover a socialização da criança pelo enriquecimento de suas experiências (RODRIGUES, 2012).

No Ursinho Dourado a turma escolhida foi o Jardim I que correspondia à turma com mais alunos no período vespertino com 15 alunos entre 3 e 4 anos para realização da coleta de dados. A mesma ocorreu em duas etapas, a saber:

a) Aplicação de questionário específico para as crianças pela professora aconteceu no dia 10 de maio de 2012, às 13h30min com duração de duas horas. Todos os alunos (7 meninas e 8 meninos) do Jardim I estavam presentes. O questionário (conferir figura 15) continha desenhos de um computador, um notebook, um videogame, um celular, o Snoopy (personagem de desenho animado) usando um computador e a imagem de um tablet com o homem aranha, com objetivo de saber o contato das crianças com aparelhos tecnológicos. Os pequenos estudantes da escola Ursinho Dourado não possuem contato com computadores ou outro tipo de tecnologia da informação no âmbito da escola, com exceção do aparelho televisor.

Nesta etapa, verificou-se que as quinze crianças em questão tiveram e ainda mantém contato com algum instrumento digital em casa. A maioria, 13 dos 15 alunos brincam com os celulares dos pais. 
Figura 14 Questionário para as crianças na escola Ursinho Dourado

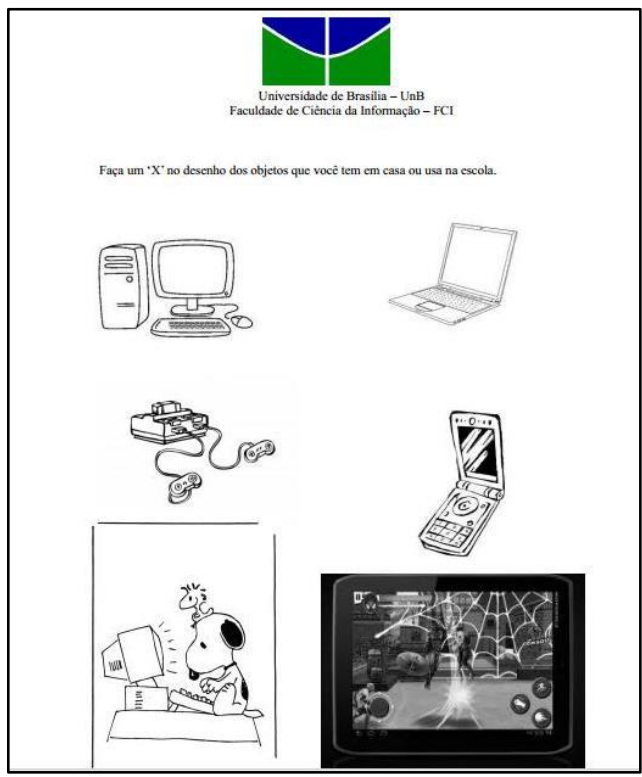

Fonte: (RODRIGUES, 2012).

b) A observação ocorreu em 25 de maio de 2012. Realizou-se atividades planejadas utilizando informações digitais lúdicas. As crianças foram divididas em grupos devido a falta de computadores para todas. Foram disponibilizados para os alunos 2 notebooks com mouse, 1 netbook sem mouse. Preparados com atalhos para o software utilizado para criar desenhos e editar imagens paint, Internet explorer, Mozilla e Chrome para acessar à internet. $O$ desenvolvimento das atividades ocorreu seguindo simples roteiro: navegação livre, em que os alunos exploram a interface o paint e o chrome; navegação direcionada aos sites smartkids e Friv (ver figura 16 e 17); atividade com livro digital infantil "A joaninha vaidosa" disponível no portal Biblioteca de Livros Digitais de Portugal.

Um dos alunos de quatro anos acessou o Chrome e digitou a letra "c". Questionado sobre essa atitude respondeu que a mãe havia Ihe ensinado a teclar o "c" no Google para acessar o site Clickjogos $^{18}$, que aparece como dica do Google. O que essa mãe ensinou, sem o propósito, pode ser considerado uma forma de busca de informação, o princípio, talvez, de uma competência informacional. O garoto teve a necessidade de jogar (necessidade de informação), buscou o jogo e o recuperou para brincar atingindo seu objetivo e utilizando efetivamente a informação. As crianças foram direcionadas ao site de jogos Smartkids ${ }^{19}$, porém, as crianças

\footnotetext{
${ }^{18}$ www.clickjogos.com.br

${ }^{19}$ www.smartkids.com.br
} 
começaram a navegar pelo ambiente digital com algumas dificuldades, mas logo clicavam no ícone dos jogos que mais lhes chamavam a atenção.

A escolha pelo Smartkids se deu por abordar vários conteúdos considerados, efetivamente, educativos em seus jogos e mais atividades para colorir e passatempos, além de ter espaço para o professor e espaço para bebês, o smartbabies, entretanto, a interface possui muito texto além dos jogos. Os fatores considerados negativos foram o apelo comercial de alguns produtos no site e a venda de alguns jogos, porém a proposta educacional é válida e enriquecedora.

A interface do Smartkids apresenta cores chamativas, menu aparentemente fácil, porém algumas das crianças não conseguiriam acessá-lo sozinhas, apontavam o jogo que queriam para que alguém pudesse acessar para elas. As meninas escolheram o jogo Cara Pintada, cujo objetivo é pintar o cabelo, mudar a cor dos olhos e a maquiagem. Os meninos escolheram o jogo de memória. Essa escolha pode ser explicada pela questão de gênero, apontada por Souza et al. (2009) no artigo Games e gênero: a emergência dos personagens femininos.

Figura 15 tela da interface em que se encontram os jogos no smartkids

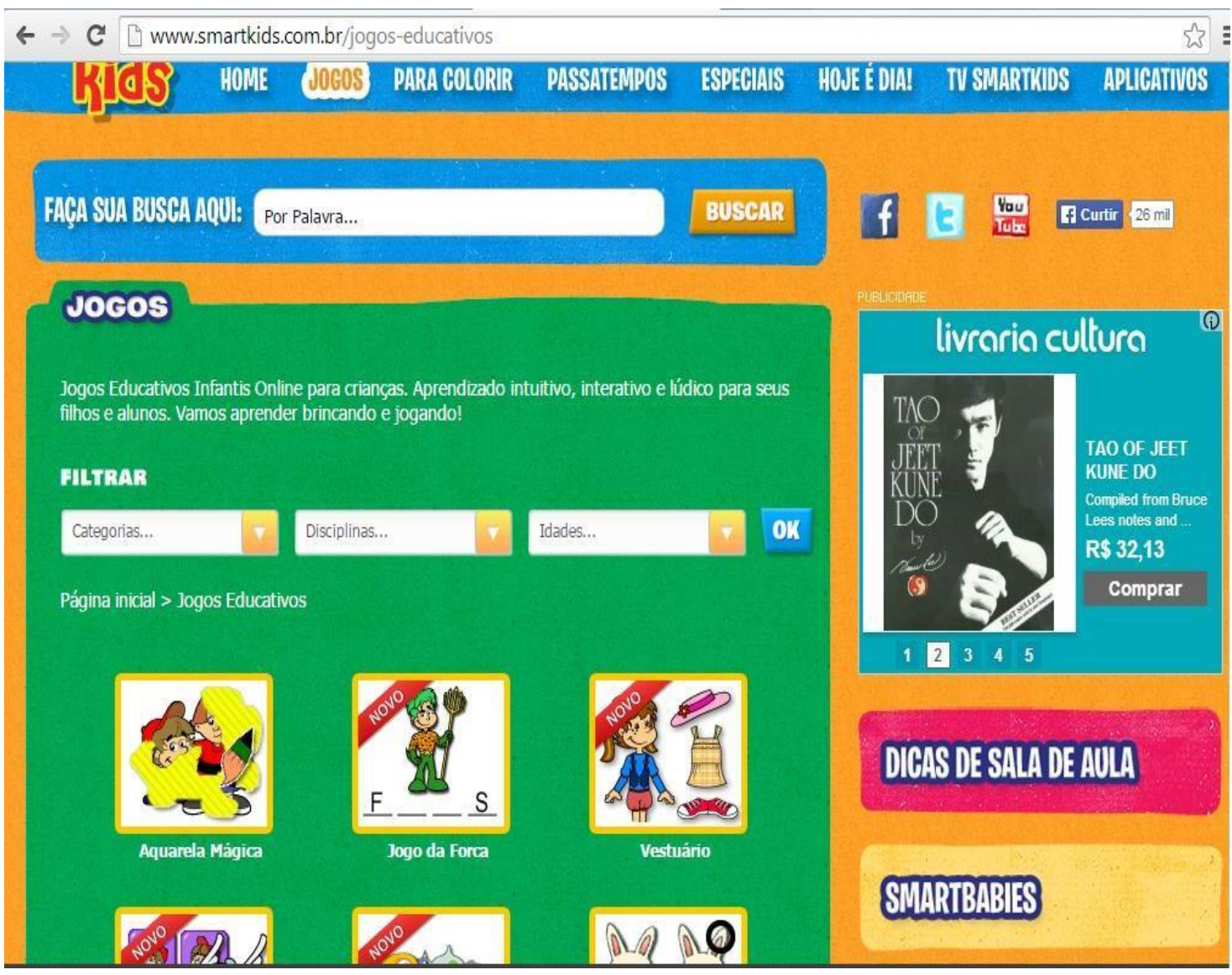

Fonte: SMARTKIDS, 2015. 
Figura 16 interface inicial do Friv

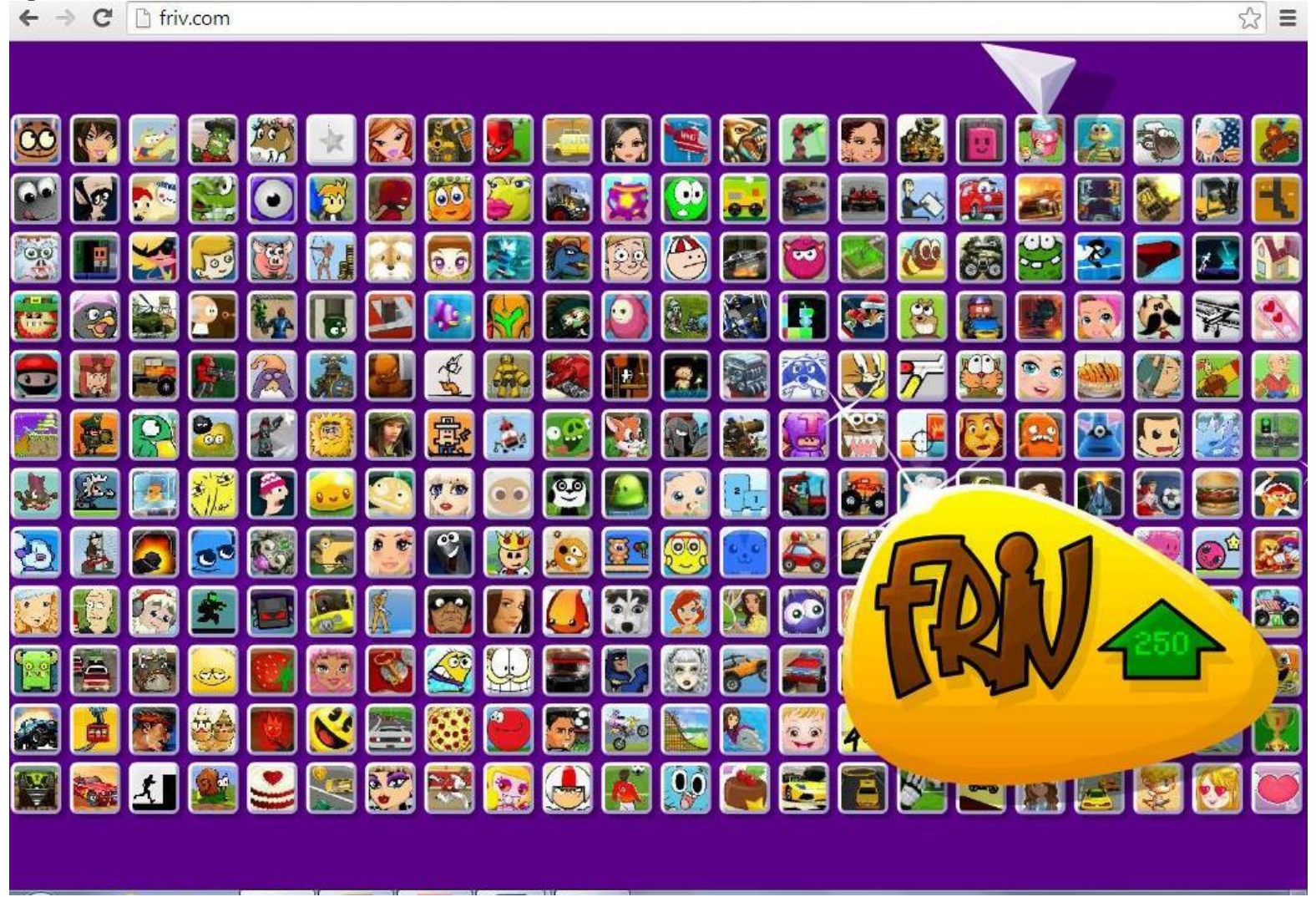

Fonte: FRIV, 2015.

Durante a realização das atividades na escola Ursinho Dourado, as crianças demonstraram diversos tipos de comportamentos e sentimentos em relação às informações apresentadas, como pode ser observadas no quadro 4.

Quadro 4 Escola Ursinho Dourado

\begin{tabular}{|c|c|c|}
\hline \multicolumn{3}{|c|}{ Escola Ursinho Dourado - Jardim I turma: A } \\
\hline $\begin{array}{l}\text { Período/ } \\
\text { Idade }\end{array}$ & Atividade & Comportamento/reações \\
\hline $\begin{array}{l}3 \text { anos e } 4 \\
\text { anos }\end{array}$ & $\begin{array}{l}\text { Utilizaram paint; } \\
\text { Jogaram Smartkids; } \\
\text { Jogaram FRIV e fizeram } \\
\text { "leitura" de livro digital. }\end{array}$ & $\begin{array}{l}\text { - trocavam informações sobre cores e } \\
\text { imagens possíveis de serem criadas no paint; } \\
\text { - garoto de } 4 \text { anos usou o como buscador de } \\
\text { jogos, digitando a letra "c" para jogar no } \\
\text { clickjogos; } \\
\text { - pediram ajuda ao professor; } \\
\text { - seleção de jogos por gênero; } \\
\text { - concentração; } \\
\text { - persistência, apesar de alguns momentos } \\
\text { desistirem de jogos difíceis; } \\
\text { - tristeza; } \\
\text { - raiva; }\end{array}$ \\
\hline
\end{tabular}




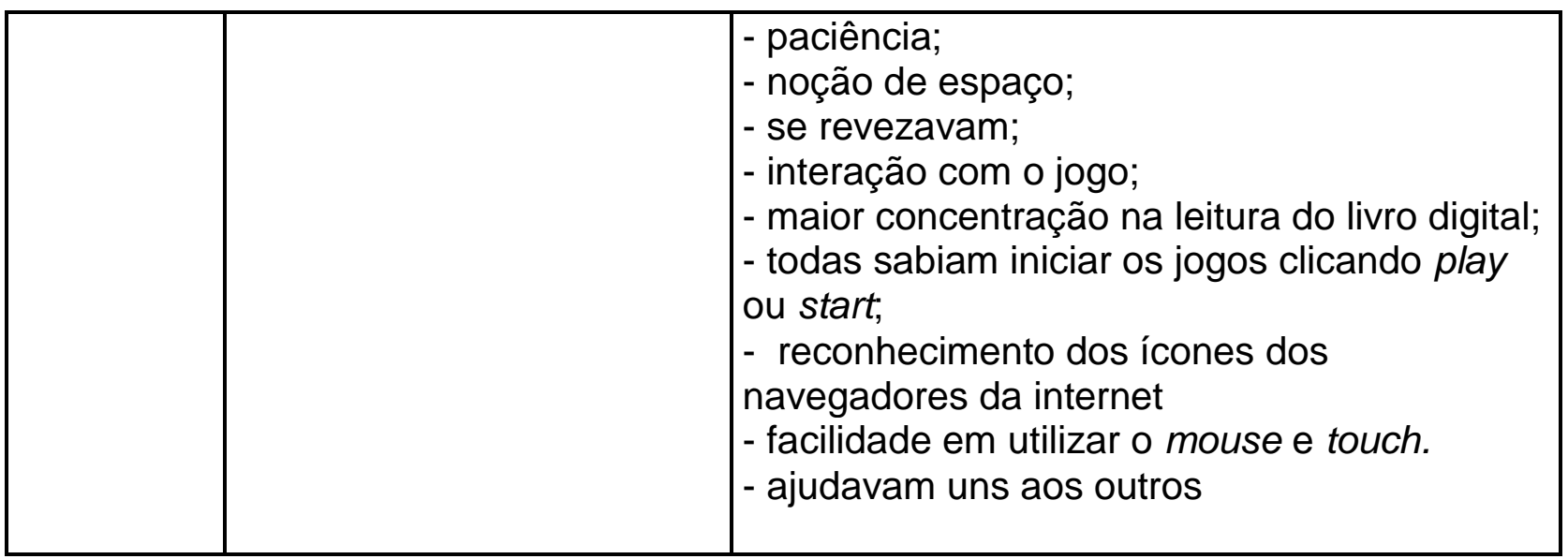

Fonte: Elaboração própria.

No momento em que as crianças estavam jogando e o jogo apresentava alguma dificuldade em passar de fase ou de conseguir iniciar o jogo elas expressavam raiva ou/e tristeza. Durante o jogo que exigisse atenção os pequenos demonstraram concentração, mesmo que por pouco tempo.

Apesar das crianças estarem no estágio pré-operacional, de acordo com as etapas expostas por Piaget apresentadas anteriormente no quadro 2, uma das características é o egocentrismo, elas se mostraram solidárias ao trocar informações em relação aos jogos e a sair do seu lugar para ajudar outro colega a jogar.

\subsection{ESCOLA FRANCISCANA NOSSA SENHORA DE FÁTIMA}

A Escola Franciscana Nossa Senhora de Fátima foi criada em 1960 situada na Asa Sul ligada a mais 10 escolas, 01 centro universitário e 01 Instituto Superior Franciscano. A Escola Fátima tem como missão desenvolver os serviços educacionais de acordo com os ideais franciscanos, contribuindo da melhor forma com a formação de cidadãos. A escola atende alunos desde o berçário ao ensino médio. Possui cerca de 300 alunos na educação infantil distribuídos em 23 turmas nos períodos matutino e vespertino.

Na Escola Fátima a atividade foi realizada em sala de aula e no laboratório II em 21 de fevereiro de 2013, das 14h às 16h50min, com a turma do Jardim I composta de 13 alunos entre 3 e 5 anos, sendo 9 meninas e 4 meninos. Os alunos participam uma vez por semana de atividade no laboratório de informática com o software EducatuX, que promete propiciar ao aluno o aprendizado de forma lúdica. 
Houve a apresentação pela educadora e pesquisadoras para os alunos da Escola Fátima da primeira atividade (ver figura 18) que consistia em marcar um "X" e pintar os objetos digitais, que elas tinham contato em casa e/ou na escola. Algumas crianças confundiram a imagem do tablet. 5 delas acharam que era um espelho, 1 pensou que fosse uma janela e somente 3 disseram que era o lpad ou fizeram referência ao tablet. (RODRIGUES; MENDES; KAFURE, 2013).

Figura 17 atividade aplicada aos alunos da Escola Franciscana Nossa Senhora de Fátima

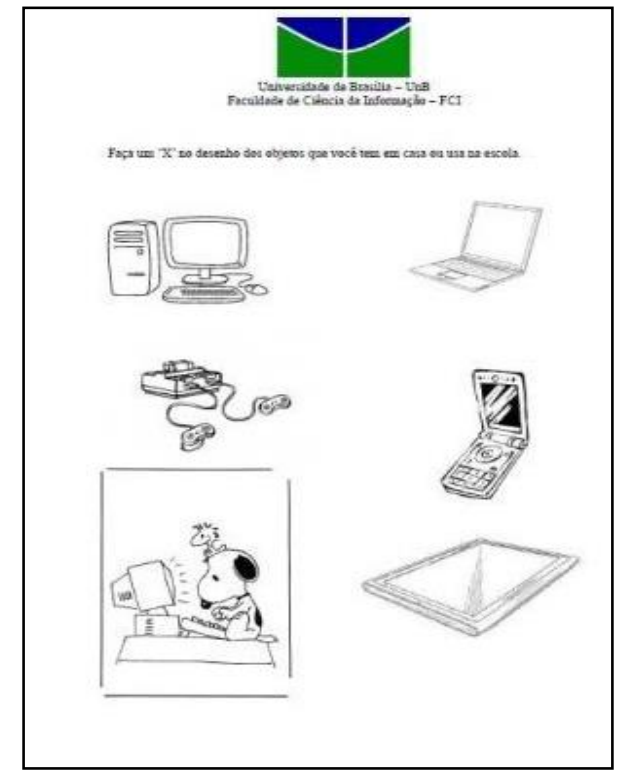

Fonte: RODRIGUES, MENDES, KAFURE, 2013.

O sistema operacional utilizado pela escola Fátima é o Edubuntu. Por essa razão, não foi possível à utilização do Internet Explorer. Para cada aluno havia um computador. No desktop criaram-se atalhos do Google Chrome, Mozilla e do Kolorpaint (software utilizado para a criação de desenhos simples e para edição de imagens do Linux semelhante ao paint do Windows)

Primeiramente, os alunos exploraram as ferramentas expostas no desktop. A maioria utilizou o Kolorpaint e fizeram desenhos coloridos. Logo em seguida, navegaram pelo Smartkids, seguindo o roteiro de atividades. As crianças sentiram dificuldade em encontrar os jogos e a todo o momento pediram ajuda, assim como os alunos da escola Ursinho Dourado.

De modo geral a reação deles perante a interface do site foi satisfatória, mas constatou-se que as atividades trabalhadas com o Smartkids requerem mais tempo e planejamento detalhado. 
O portal de jogos Friv contém mais de 250 jogos em formato flash. Quando se navega pela tela principal, constata-se que o site contém miniaturas dos jogos que são disponibilizados e, ao mover o cursor do mouse pela interface, o usuário vê o nome do jogo e para jogar é só clicar. O portal possui propaganda, quando escolhem algum jogo no instante que estão carregando aparecem apelo comercial e observou-se, também, que cada jogo pertence a um site específico, inferindo que o Friv pode ser considerado uma espécie de catálogo de jogos. Para utilizá-lo como recurso pedagógico, é aconselhável realizar um estudo sobre os jogos que estão disponibilizados e escolher um ou mais, dependendo da atividade que o educador quer proporcionar as crianças.

Os alunos da Escola Fátima também apresentaram diversas reações durante as atividades observadas, conforme quadro 5. Destaque para uma aluna acessando o vídeo no youtube mesmo sem áudio e demonstrando alegria ao assisti-lo. Alguns alunos demonstraram concentração nos jogos mais difíceis, assim como, impaciência e persistência.

Quadro 5 Escola Franciscana Nossa Senhora de Fátima

\begin{tabular}{|c|c|c|}
\hline \multicolumn{3}{|c|}{ Escola Franciscana Nossa Senhora de Fátima - Jardim I } \\
\hline $\begin{array}{l}\text { Período/ } \\
\text { Idade }\end{array}$ & Atividade & Comportamento/reações \\
\hline $\begin{array}{l}3 \text { anos e } 5 \\
\text { anos }\end{array}$ & $\begin{array}{l}\text { Usaram Kolorpaint; } \\
\text { Jogaram Smartkids; } \\
\text { Jogaram FRIV }\end{array}$ & $\begin{array}{l}\text { - desenhando no paint; } \\
\text { - interação; } \\
\text { - ensinavam uns aos outros; } \\
\text { - alegria; } \\
\text { - impaciência; } \\
\text { - facilidade em utilizar o mouse; } \\
\text { - dificuldade em acessar alguns jogos; } \\
\text { - persistência }\end{array}$ \\
\hline
\end{tabular}

Fonte: Elaboração própria 


\subsection{COLÉGIO SANTA MARIA}

Colégio Santa Maria, erguido em 2000, recebeu o nome da cidade satélite situada no Distrito Federal. Preza pela filosofia de qualidade na educação e busca integração da família no decorrer do processo. Atendem crianças do maternal ao ensino médio. As crianças a partir do maternal III frequentam o laboratório de informática, assim como as demais uma vez por semana.

A proposta da instituição é proporcionar o contato livre nos computadores, isto é, deixá-las explorarem, jogarem à vontade durante o período permaneceram no laboratório.

Os participantes correspondem a 5 turmas, 2 jardim I, 2 jardim II e 1 maternal III, crianças entre três e cinco anos. As observações ocorreram nos dias 19, 20, 26, 27 de maio e 2, 3 de junho de 2014 no período vespertino. Foram observadas 64 crianças entre 3 e 5 anos.

O laboratório é composto por 32 máquinas, com sistema operacional Windows 7.

Os resultados das observações podem ser conferidos nos quadros 6, 7, 8, 9 e 10. Os quadros estão dispostos por período escolar e idades assim como as observações correspondentes.

Quadro 6 Crianças do Maternal III - Colégio Santa Maria

\begin{tabular}{|c|l|l|}
\hline \multicolumn{2}{|c|}{ COLÉGIO SANTA MARIA - Maternal III } \\
\hline $\begin{array}{c}\text { Idade/ } \\
\text { Quantidade/ } \\
\text { gênero }\end{array}$ & \multicolumn{1}{|c|}{ Atividade } & \multicolumn{1}{c|}{ Comportamento/reações } \\
\hline & $\begin{array}{l}\text { Jogos no friv; escola } \\
\text { games e desenho animado } \\
\text { as vezes programado } \\
\text { pelas professoras e outras } \\
\text { anos }\end{array}$ & $\begin{array}{l}\text { - dificuldade em manusear o mouse e } \\
\text { acessar os jogos; } \\
\text { - distração; } \\
\text { meninas } \text { meninos } \\
\text { a pedido das crianças. (no } \\
\text { período observado só } \\
\text { houve uma exibição de } \\
\text { desenho, na ocasião as } \\
\text { crianças pediram para } \\
\text { assistir o pica-pau). }\end{array}$ \\
\hline
\end{tabular}


\begin{tabular}{|l|l|l|}
\hline & & - impaciência \\
\hline
\end{tabular}

Fonte: Elaboração própria.

Apesar da pouca idade dos alunos do maternal 3, demonstraram pontos em comuns com crianças entre 4 e 5 anos da mesma escola e de outras instituições.

Outra turma observada foi a do Jardim 1 (ver quadro 7) as crianças conversaram bastante entre elas. Destaque para um menino jogando jogo considerado feminino, Red velvet Cake. Outra criança acessou e selecionou o vídeo do personagem infantil, galinha pintadinha, no youtube sem áudio. Os alunos atribuíam sentimentos aos personagens, por exemplo, se o herói do jogo fosse golpeado eles produziam o som de dor.

Quadro 7 Crianças do Jardim IA - Colégio Santa Maria

\begin{tabular}{|c|c|c|}
\hline $\begin{array}{l}\text { Idade/ } \\
\text { Quantidade/ } \\
\text { qênero }\end{array}$ & Atividade & Comportamento/reações \\
\hline $\begin{array}{c}\text { 4anos } \\
9 \text { meninas } \\
6 \text { meninos }\end{array}$ & $\begin{array}{l}\text { - Jogaram no FRIV } \\
\text { - } 1 \text { criança abriu e assistiu } \\
\text { o vídeo da galinha } \\
\text { pintadinha no youtube } \\
\text { (sem áudio) selecionada } \\
\text { por ela mesma. }\end{array}$ & $\begin{array}{l}\text {-Conversam entre eles; } \\
\text { - Garoto jogando o Red velvet cake, jogo } \\
\text { considerado feminino; } \\
\text { - Ensinam uns aos outros; } \\
\text { - Conflitos; } \\
\text { - Atribuição de sentimentos aos } \\
\text { personagens; } \\
\text { - alegria; } \\
\text { - concentração; }\end{array}$ \\
\hline
\end{tabular}

Fonte: Elaboração própria. 
Quadro 8 Crianças do Jardim IB - Colégio Santa Maria

\begin{tabular}{|c|c|c|}
\hline \multicolumn{2}{|c|}{ COLÉGIO SANTA MARIA - Jardim I turma B } \\
\hline $\begin{array}{c}\text { Idade/ } \\
\text { Quantidade/ } \\
\text { gênero }\end{array}$ & \multicolumn{1}{|c|}{ Atividade } & \multicolumn{1}{c|}{ Comportamento/reações } \\
\hline $\begin{array}{c}\text { 4anos } \\
5 \text { meninas }\end{array}$ & Jogaram FRIV & $\begin{array}{l}\text { - interagem entre eles; } \\
\text { - impaciência; } \\
\text { - menina cantando enquanto joga; } \\
\text { - alegria em vencer; } \\
\text { - jogam em grupos; } \\
\text { - uns ensinando os outros; }\end{array}$ \\
\hline
\end{tabular}

Fonte: Elaboração própria.

Quadro 9 Crianças Jardim II - Colégio Santa Maria

\begin{tabular}{|l|l|l|}
\hline \multicolumn{2}{|c|}{ COLÉGIO SANTA MARIA - Jardim II turma: A } \\
\hline $\begin{array}{c}\text { Período/ } \\
\text { Idade }\end{array}$ & \multicolumn{1}{|c|}{ Atividade } & \multicolumn{1}{c|}{ Comportamento/reações } \\
\hline & & $\begin{array}{l}\text { - garoto acessou o mozilla; } \\
\text { - interação entre eles a respeito dos jogos } \\
\text { - Percepção das cores; }\end{array}$ \\
$\begin{array}{l}4 \text { anos e 5 } \\
\text { anos }\end{array}$ & Jogaram FRIV & \\
\hline
\end{tabular}

Fonte: Elaboração própria.

Quadro 10 Crianças Jardim IIA - Colégio Santa Maria

\begin{tabular}{|c|c|l|}
\hline \multicolumn{2}{|c|}{ COLÉGIO SANTA MARIA - Jardim II turma: B } \\
\hline Período/ & \multicolumn{1}{|c|}{ Atividade } & \multicolumn{1}{c|}{ Comportamento/reações } \\
\hline Idade & \multicolumn{1}{|c|}{$\begin{array}{l}\text { - Utilização do termo "adorar" por algumas } \\
\text { crianças jogando o Pac-xon; } \\
\text { - impaciência quando acessam o jogo difícil; } \\
\text { - minimizaram e maximizaram a janela; } \\
\text { - garotos oferecem ajuda ao outro; } \\
\text { - desistência de um garoto. Escolheu ficar } \\
\text { com a professora. } \\
\text { - ansiedade; } \\
\text { - grupo de 3 meninas dançando durante a }\end{array}$} \\
\hline meninas \\
\hline Jominos
\end{tabular}




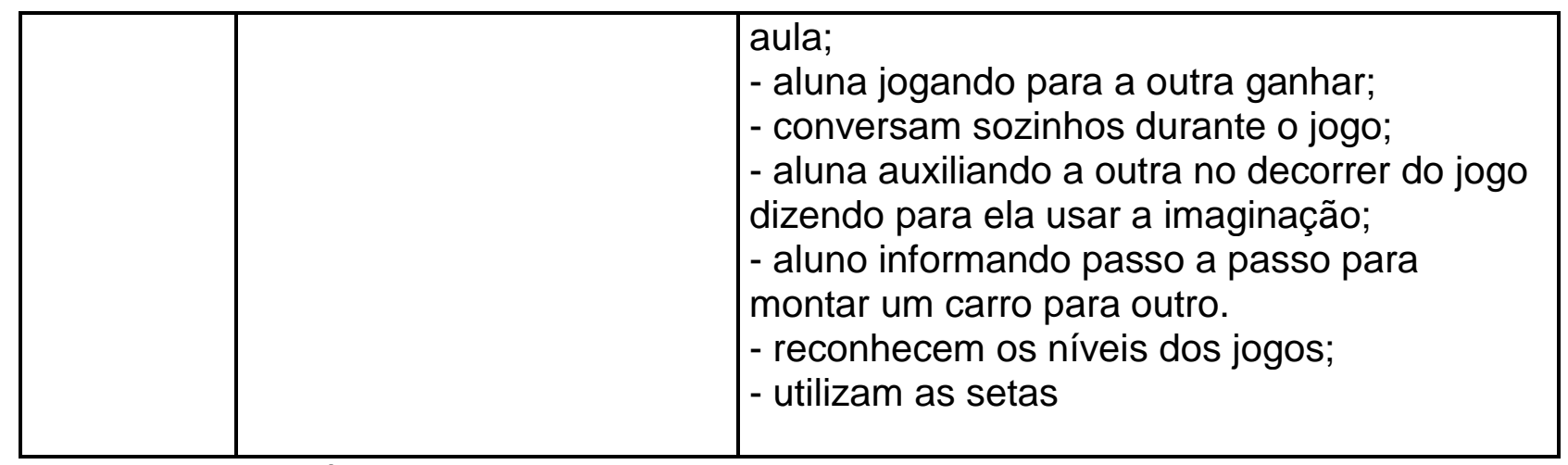

Fonte: Elaboração própria.

\subsection{COLÉGIO LA SALLE BRASÍLIA}

Outra escola observada foi o Colégio La Salle de Brasília fundado em 1962. Possui como missão educar seguindo os preceitos de São João Batista de La Salle. Tem por objetivo a educação de qualidade utilizando metodologia adequada para seus alunos. Estimula o uso dos recursos e atividades que tratem os conteúdos de forma contextualizada e interdisciplinar. Na educação infantil, o La Salle Brasília, acolhe crianças desde creche ao primeiro ano. Prezam o desenvolvimento global da criança. O La Salle Brasília atende estudantes desde a creche até o ensino médio.

As crianças estudadas correspondem à pré-escola (Infantil IV e V) entre 4 e 5 anos.

O laboratório de informática é composto por trinta máquinas equipadas com sistema operacional Windows 7. A observação ocorreu nos dias 08 e 15 de setembro de 2014 com crianças do infantil IV e V, totalizando 64 crianças.

O responsável pelas aulas é o professor Tiago Costa, 30 anos, graduado em Sistemas de Informação, possui especialização em educação infantil. $\mathrm{Na}$ ocasião em que as turmas vão ao laboratório de informática/robótica uma monitora as acompanham e permanece por todo período de aula. As aulas no laboratório são direcionadas a fixar o conteúdo trabalhado em sala.

No início do ano de 2014 essas crianças aprenderam a utilizar o mouse e teclado. Como recurso, o professor utilizou os jogos de forma livre. Já no segundo semestre, apesar de algumas apresentarem dificuldades, mostram-se mais independentes ao uso do computador, realização das atividades no smartkids e aos jogos no friv. 
Quadro 11 Colégio La Salle Brasília Infantil IV

\begin{tabular}{|c|c|c|}
\hline \multicolumn{3}{|c|}{ COLÉGIO La Salle Brasília - Infantil IV } \\
\hline $\begin{array}{c}\text { Idade/ } \\
\text { Quantidade/ } \\
\text { gênero }\end{array}$ & Atividade & Comportamento/reações \\
\hline $\begin{array}{c}4 \text { anos } \\
14 \text { meninas } \\
12 \text { meninos }\end{array}$ & $\begin{array}{l}\text { Jogaram "Alfabeto em } \\
\text { português } 1 \text { " no smartkids. } \\
\text { Após concluírem jogam } \\
\text { jogos do Friv. }\end{array}$ & $\begin{array}{l}\text { - conversam entre si; } \\
\text { - apresentam dificuldade na execução da } \\
\text { atividade; } \\
\text { - desinteresse; } \\
\text { - interesse; } \\
\text { - concentração; } \\
\text { - prof. ensina os sons das palavras; } \\
\text { - algumas crianças pareciam não gostar da } \\
\text { atividade no smartkids; } \\
\text { - queriam acabar logo para jogar o Friv; }\end{array}$ \\
\hline
\end{tabular}

Fonte: Elaboração própria..

As duas turmas de infantil IV era composta de 36 alunos matriculados sendo 22 meninas e 14 meninos. As informações expostas no quadro 11 são referentes ao dia de observação e as duas turmas.

Quadro 12 Colégio La Salle Brasília Infantil V

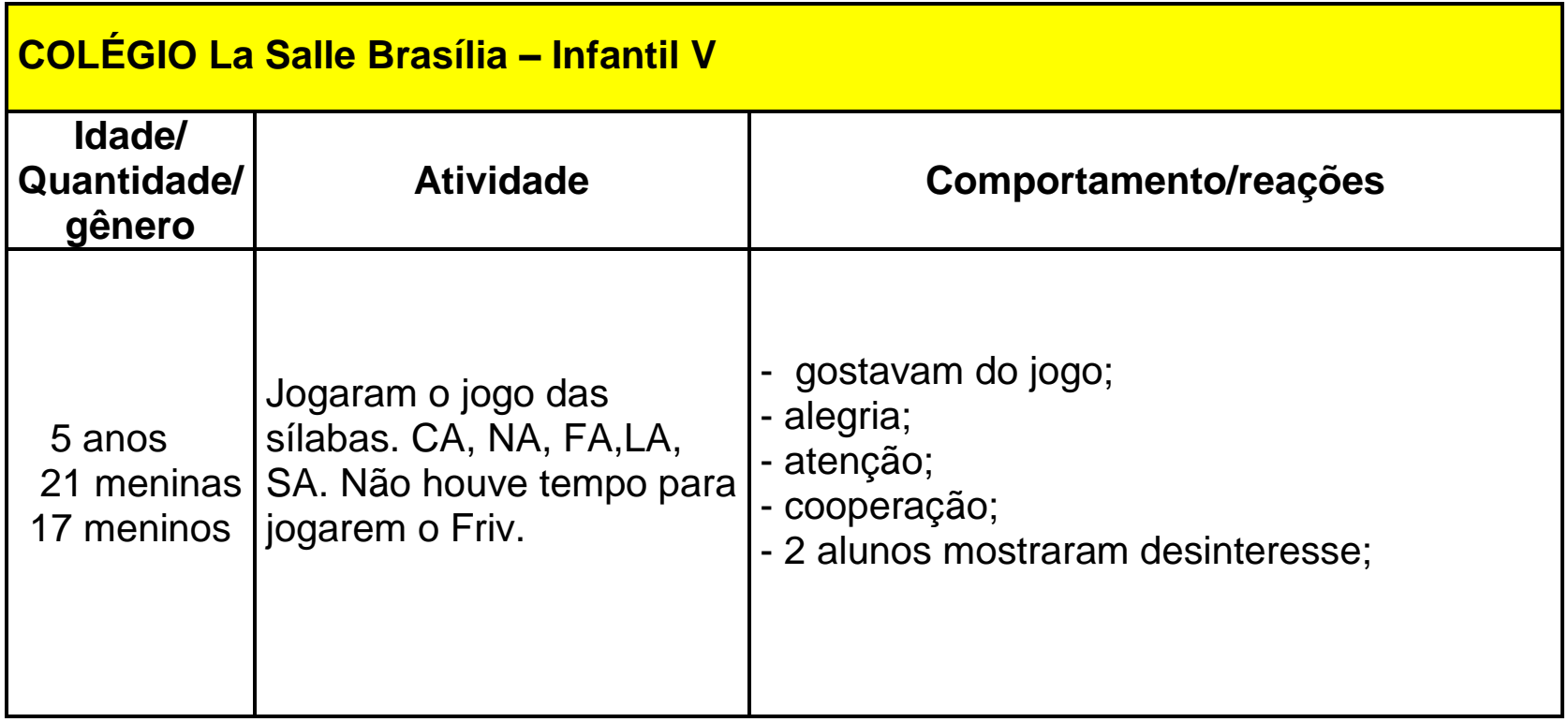

Fonte: Elaboração própria.

Das quatro turmas de infantil $\mathrm{V}$ foram observadas três o que corresponde a 42 crianças sendo 23 meninas 19 meninos com 5 anos. 
Os jogos do smartkids oferecidos aos alunos do Colégio La Salle durante as aulas são selecionados pelo professor Tiago, segue no quadro 11 a descrição dos jogos assim como objetivos e nome.

Quadro 13 Jogos trabalhados com os pequenos alunos do colégio La Salle de Brasília

\begin{tabular}{|c|c|c|}
\hline SMARTKIDS & OBJETIVO & DESCRIÇÃO \\
\hline $\begin{array}{c}\text { Alfabeto } \\
\text { Português I }\end{array}$ & $\begin{array}{c}\text { Descobrir a palavra } \\
\text { que corresponde a letra } \\
\text { exposta. }\end{array}$ & $\begin{array}{c}\text { Consiste em observar a } \\
\text { letra da vez e descobrir } \\
\text { qual figura } \\
\text { correspondente e arrastar } \\
\text { para o quadrado ao lado } \\
\text { da letra. }\end{array}$ \\
\hline $\begin{array}{l}\text { Jogo do } \\
\text { alfabeto em } \\
\text { flash }\end{array}$ & $\begin{array}{l}\text { Tem o mesmo proposto } \\
\text { do alfabeto português I. } \\
\text { Porém, mas dinâmico }\end{array}$ & $\begin{array}{l}\text { Observar a letra da vez e } \\
\text { descobrir qual figura } \\
\text { correspondente e arrastar } \\
\text { para o quadrado em } \\
\text { branco }\end{array}$ \\
\hline $\begin{array}{c}\text { Jogo das } \\
\text { sílabas (BA, CA, } \\
\text { DA, FA, LA, MA, } \\
\text { NA, PA, RA, } \\
\text { SA, TA) }\end{array}$ & $\begin{array}{l}\text { Encontrar a palavra } \\
\text { correspondente a } \\
\text { sílaba pré-estabelecida } \\
\text { e fazer mais pontos. }\end{array}$ & $\begin{array}{l}\text { Primeiramente, escolhe } \\
\text { entre o avatar de menina } \\
\text { (Tina) ou de menino } \\
\text { (Zero). Em seguida } \\
\text { aparece a sílaba e as } \\
\text { figuras. Escolhendo a } \\
\text { figura que comece com a } \\
\text { sílaba, a palavra aparece } \\
\text { abaixo da sílaba. }\end{array}$ \\
\hline
\end{tabular}

Fonte: Elaboração própria.

As escolas observadas utilizaram o site de jogos Friv como ilustrado anteriormente. Para melhor entendimento de alguns jogos utilizados pelas crianças, criou-se o quadro 14 com o nome do jogo, objetivo, descrição e possíveis competências proporcionadas pelo jogo.

Quadro 14 Jogos do site de jogos Friv utilizados pelas crianças de todas escolas

\begin{tabular}{|c|l|l|l|}
\hline JOGO DO FRIV & \multicolumn{1}{|c|}{ OBJETIVO } & \multicolumn{1}{c|}{ DESCRIÇÃo } & $\begin{array}{c}\text { POSSÍVEL } \\
\text { COMPETÉNCIA }\end{array}$ \\
\hline $\begin{array}{c}\text { Fireboy and } \\
\text { watergirl in the } \\
\text { forest temple }\end{array}$ & $\begin{array}{l}\text { Pegar os diamantes } \\
\text { correspondentes à } \\
\text { água e ao fogo } \\
\text { enfrentando os } \\
\text { obstáculos juntos, }\end{array}$ & $\begin{array}{l}\text { Dois personagens o } \\
\text { fogo (garoto) e água } \\
\text { (garota), não são } \\
\text { adversários e tem que } \\
\text { trabalharem juntos para }\end{array}$ & $\begin{array}{l}\text { Aprendem a } \\
\text { cooperar, trabalhar } \\
\text { juntos para } \\
\text { alcançar o mesmo } \\
\text { objetivo; traçar }\end{array}$ \\
\hline
\end{tabular}




\begin{tabular}{|c|c|c|c|}
\hline & $\begin{array}{l}\text { concluir as fases até } \\
\text { chegar ao estágio final. }\end{array}$ & $\begin{array}{l}\text { passar cada etapa. O } \\
\text { fogo só passa pelo fogo } \\
\text { e a água pela água se } \\
\text { ocorrer o contrário eles } \\
\text { morrem. Se um morrer } \\
\text { ambos perdem o jogo. }\end{array}$ & $\begin{array}{l}\text { estratégias; } \\
\text { paciência; } \\
\text { atenção. }\end{array}$ \\
\hline $\begin{array}{l}\text { Sara's sweet } \\
\text { cooking class - } \\
\text { red vevelt care }\end{array}$ & fazer e confeitar o bolo & $\begin{array}{l}\text { Constituído por cinco } \\
\text { fases, o jogador deve } \\
\text { pegar os ingredientes } \\
\text { (aparecem no canto } \\
\text { inferior esquerdo) de } \\
\text { cada etapa, colocá-los } \\
\text { na mesa, adicioná-los } \\
\text { na vasilha, misturá-los, } \\
\text { guardá-los, pegá-los e } \\
\text { finalmente assar o bolo, } \\
\text { fazer a cobertura e } \\
\text { confeitá-lo. }\end{array}$ & $\begin{array}{l}\text { Noção de tempo; } \\
\text { Noção de } \\
\text { medidas; e } \\
\text { direção. }\end{array}$ \\
\hline $\begin{array}{l}\text { Rapunzel facial } \\
\text { makeover }\end{array}$ & $\begin{array}{c}\text { Preparar a Rapunzel } \\
\text { para sair. }\end{array}$ & $\begin{array}{l}\text { O jogador deve lavar e } \\
\text { tratar a face da } \\
\text { Rapunzel, após esses } \\
\text { cuidados maquiá-la, } \\
\text { penteá-la, adicionar } \\
\text { adereços como brincos } \\
\text { e colar. }\end{array}$ & $\begin{array}{l}\text { Noção de higiene } \\
\text { facial; }\end{array}$ \\
\hline $\begin{array}{l}\text { Monster High } \\
\text { Rock Band }\end{array}$ & $\begin{array}{c}\text { Produzir as cinco } \\
\text { integrantes da Monster } \\
\text { High. }\end{array}$ & $\begin{array}{l}\text { Escolher uma das } \\
\text { integrantes da banda e } \\
\text { em seguida escolher } \\
\text { roupa, calçado, } \\
\text { acessórios, maquiagem } \\
\text { e cenário para o show. } \\
\end{array}$ & $\begin{array}{c}\text { Noção de } \\
\text { vestimentas; } \\
\text { noção do corpo; } \\
\text { cores }\end{array}$ \\
\hline Rich Cars & $\begin{array}{l}\text { Passar pelas fases } \\
\text { superando os } \\
\text { obstáculos e seguir até } \\
\text { a fase final. }\end{array}$ & $\begin{array}{l}\text { Composto por } 9 \text { fases. } \\
\text { O carro deve fazer todo } \\
\text { percurso superando os } \\
\text { pequenos obstáculos e } \\
\text { adquirindo os diamantes } \\
\text { roxos e vidas. }\end{array}$ & $\begin{array}{l}\text { Raciocínio lógico, } \\
\text { estratégia, } \\
\text { atenção, espaço }\end{array}$ \\
\hline Unfreeze me & $\begin{array}{l}\text { Libertar o personagem } \\
\text { do gelo. }\end{array}$ & $\begin{array}{l}\text { Pressionar a vasilha } \\
\text { com substância que } \\
\text { derreta o gelo para } \\
\text { libertar o ou os } \\
\text { personagens presos nas } \\
\text { fases. }\end{array}$ & $\begin{array}{l}\text { Trabalha noção de } \\
\text { tamanhos } \\
\text { (pequeno, médio e } \\
\text { grande) e espaço. }\end{array}$ \\
\hline
\end{tabular}




\begin{tabular}{|c|c|c|c|}
\hline $\begin{array}{l}\text { My Dolphn } \\
\text { Show }\end{array}$ & $\begin{array}{c}\text { Fazer show com } \\
\text { golfinho, manter o } \\
\text { público e fazer pontos } \\
\text { no tempo determinado. }\end{array}$ & $\begin{array}{l}\text { Utilizar a setas e fazer } \\
\text { com que o golfinho } \\
\text { toque a bola, saltar } \\
\text { argolas, pegar peixes e } \\
\text { estrelas. }\end{array}$ & $\begin{array}{l}\text { Coordenação } \\
\text { motora; raciocínio; }\end{array}$ \\
\hline Pac-xon & $\begin{array}{c}\text { o pac-xon deve } \\
\text { percorrer os espaços } \\
\text { vazios para preenchê- } \\
\text { los até mais de } 80 \% \\
\text { não deixando os } \\
\text { inimigos encostar nele. }\end{array}$ & Possui 50 fases. & Noção espacial; \\
\hline $\begin{array}{c}\text { Rollercoaster } \\
\text { Creater }\end{array}$ & $\begin{array}{l}\text { Levar as pessoas para } \\
\text { o outro lado da } \\
\text { montanha construindo } \\
\text { trilhos para o carrinho } \\
\text { passar. Criando uma } \\
\text { montanha russa. }\end{array}$ & $\begin{array}{l}\text { Composto por } 21 \text { fases. } \\
\text { Com o mouse o jogador } \\
\text { faz o desenho dos } \\
\text { trilhos onde o carrinho } \\
\text { com as pessoas fará o } \\
\text { percurso. Caso haja } \\
\text { falha no percurso o } \\
\text { carrinho cai. As moedas } \\
\text { que aparecem devem } \\
\text { ser pegas. }\end{array}$ & $\begin{array}{l}\text { Coordenação } \\
\text { motora; noção } \\
\text { espacial; }\end{array}$ \\
\hline $\begin{array}{l}\text { Barbie Ladie } \\
\text { Gaga }\end{array}$ & $\begin{array}{c}\text { Vestir a Barbie como a } \\
\text { cantora Lady Gaga. }\end{array}$ & $\begin{array}{l}\text { Enfeitar as unhas, } \\
\text { escolher anéis, fazer o } \\
\text { cabelo, maquiagem, } \\
\text { roupa, calçado e } \\
\text { acessório. }\end{array}$ & Cores; formas; \\
\hline Boo or boom & $\begin{array}{c}\text { Pegar a maior } \\
\text { quantidade de doces } \\
\text { de Hallowen }\end{array}$ & $\begin{array}{l}\text { Escolher um dos } \\
\text { personagens do } \\
\text { desenho animado do } \\
\text { SpongeBob } \\
\text { SquarePants (Bob } \\
\text { Esponja Calça } \\
\text { Quadrada), eles } \\
\text { disputam para pegar a } \\
\text { maior quantidade de } \\
\text { doces. Eles podem jogar } \\
\text { bombas para descobrir } \\
\text { onde ficam os doces. } \\
\end{array}$ & $\begin{array}{l}\text { Coordenação } \\
\text { motora }\end{array}$ \\
\hline Papa's Pizzeria & $\begin{array}{c}\text { Fazer pizzas e entregá- } \\
\text { las aos clientes da } \\
\text { pizzaria. }\end{array}$ & $\begin{array}{l}\text { O jogador encontra-se } \\
\text { sozinho na pizzaria, } \\
\text { tendo que preparar } \\
\text { todos os pedidos de } \\
\text { pizza. O cliente escolhe } \\
\text { os ingredientes da pizza. } \\
\text { Assa, corta em fatias } \\
\text { conforme a quantidade } \\
\text { indicada pelo cliente. } \\
\text { Recebe o pagamento e } \\
\text { a pontuação. }\end{array}$ & $\begin{array}{l}\text { Noção de } \\
\text { organização, } \\
\text { noção de } \\
\text { funcionamento de } \\
\text { uma pizzaria; }\end{array}$ \\
\hline Dream date & Mudar o visual da & Cortar o cabelo; passar & Noçã \\
\hline
\end{tabular}




\begin{tabular}{|c|c|c|c|}
\hline dress up & $\begin{array}{l}\text { personagem para } \\
\text { combinar com os } \\
\text { cenários propostos. }\end{array}$ & $\begin{array}{l}\text { chapinha; colocar rolos } \\
\text { no cabelo, escovar, } \\
\text { pintar e utilizar diversos } \\
\text { enfeites. Escolher } \\
\text { roupas, sapatos, } \\
\text { chapéus e adornos. No } \\
\text { final o visual tem que } \\
\text { estar de acordo com o } \\
\text { cenário e isso são } \\
\text { medidos por } \\
\text { porcentagem. }\end{array}$ & $\begin{array}{l}\text { vestimenta; } \\
\text { caracterização de } \\
\text { ambiente. }\end{array}$ \\
\hline Adam and Eve & $\begin{array}{c}\text { Auxiliar o Adam a } \\
\text { passar pelos } \\
\text { obstáculos até chegar } \\
\text { ao "paraíso" e } \\
\text { encontrar Eve. }\end{array}$ & $\begin{array}{l}\text { O jogador explora o } \\
\text { ambiente com mouse } \\
\text { clicando nos obstáculos } \\
\text { direcionando o Adam } \\
\text { para passar por cada } \\
\text { fase. No jogo é } \\
\text { utilizado somente o } \\
\text { clique do mouse. }\end{array}$ & $\begin{array}{c}\text { Coordenação } \\
\text { motora e } \\
\text { estratégia. }\end{array}$ \\
\hline Red Ball & $\begin{array}{l}\text { Conduzir a bola } \\
\text { vermelha } \\
\text { ultrapassando os } \\
\text { obstáculos }\end{array}$ & & $\begin{array}{c}\text { Concentração, } \\
\text { paciência e noção } \\
\text { espacial }\end{array}$ \\
\hline Cover Orange & $\begin{array}{l}\text { Proteger a laranja da } \\
\text { chuva malvada. }\end{array}$ & $\begin{array}{l}\text { Utilizar os barris e } \\
\text { madeiras para proteger } \\
\text { a laranja da chuva; a } \\
\text { cada ação a laranja } \\
\text { expressa uma reação de } \\
\text { alegria ou tristeza. }\end{array}$ & $\begin{array}{c}\text { Concentração; } \\
\text { noção de espaço e } \\
\text { tempo; }\end{array}$ \\
\hline Hall of the Wild & $\begin{array}{c}\text { Recuperar o almoço } \\
\text { roubado da escola }\end{array}$ & $\begin{array}{l}\text { O garoto e o macaco } \\
\text { tentam recuperar o } \\
\text { almoço. Consiste em } \\
\text { conduzir os } \\
\text { personagens pela } \\
\text { escola que lembra uma } \\
\text { selva se livrando das } \\
\text { armadilhas e as vezes o } \\
\text { garoto só consegue } \\
\text { passar os obstáculos } \\
\text { por meio do macaco. } \\
\text { Eles superam cada } \\
\text { etapa até recuperar o } \\
\text { almoço. }\end{array}$ & $\begin{array}{l}\text { Concentração, } \\
\text { estratégia, } \\
\text { raciocínio lógico. }\end{array}$ \\
\hline
\end{tabular}

Fonte: Elaboração própria.

Pode-se notar que os jogos proporcionam às crianças estímulos para o desenvolvimento de algumas competências que elas utilizarão para vida toda. 
Apesar de observar instituições distintas e em regiões diferentes existem semelhanças na maneira como utilizam e interagem com a informação e entre eles. Usam os jogos em sua maioria como fonte de informação digital lúdica, além de vídeos, animação em power point.

Com propósito de adquirir mais informações para complementar o estudo e por exigência da banca examinadora de relatório intermediário de mestrado apresentada em 01 de dezembro de 2014 realizou-se a coleta final. A intenção era voltar às duas escolas, porém uma delas não atendeu à solicitação da pesquisadora para retornar à instituição.

A observação foi realizada no dia 07 de maio de 2015 no período vespertino numa turma de infantil IV no Colégio La Salle de Brasília (ver aceite institucional anexo 7). A descrição da instituição foi apresentada no item 4.4 deste trabalho. São abordados aspectos metodológicos da instituição ainda não pontuados.

A observação foi realizada em apenas uma das turmas de infantil IV com 24 alunos, 12 meninas e 12 meninos, estavam presentes 16 crianças e 1 delas portadora de deficiência física, 9 meninas e 7 meninos. O aluno com deficiência recebe acompanhamento constante de uma monitora para realizar as atividades por ter deficiência motora.

Devido à proximidade do dia das mães as crianças tiveram atividade livre utilizando o site friv.

Os alunos do infantil IV se mostraram mais receptivos e alegres neste dia. Talvez, por brincarem livremente no FRIV.

As informações referentes à coleta poderão ser observadas no quadro 15.

Quadro 15 Observações La Salle 7 maio 2015

\begin{tabular}{|c|c|c|}
\hline \multicolumn{3}{|c|}{ Colégio La Salle Brasília - Infantil IV } \\
\hline $\begin{array}{c}\text { Idade/ } \\
\text { Quantidade/ } \\
\text { gênero }\end{array}$ & Atividade & Comportamento/reações \\
\hline $\begin{array}{l}4 \text { anos } \\
9 \text { meninas } \\
7 \text { meninos }\end{array}$ & $\begin{array}{l}\text { Jogaram os seguintes } \\
\text { jogos no FRIV: Red Ball; } \\
\text { Rapunzel facial makeover } \\
\text { Sara's sweet cooking class } \\
\text { - red vevelt care, Hall of } \\
\text { the Wild, , }\end{array}$ & $\begin{array}{l}\text { - gostavam dos jogos; } \\
\text { - interação entre eles; } \\
\text { - alegria; } \\
\text { - atenção; } \\
\text { - cooperação; } \\
\text { - inquietação, agiação; } \\
\text { - frustração; } \\
\text { - brincam; }\end{array}$ \\
\hline
\end{tabular}




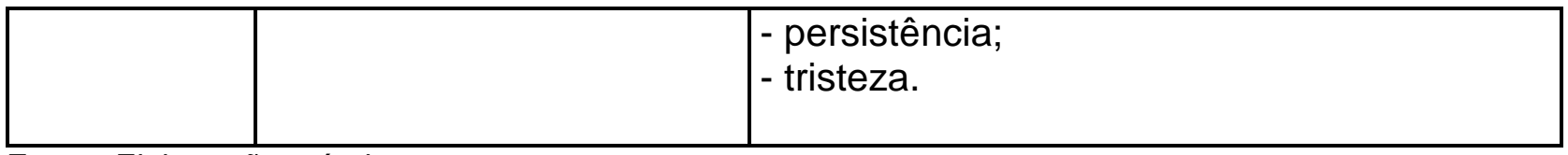

Fonte: Elaboração própria.

As informações (jogos, vídeos ou/e apresentações em power point) disponibilizadas para as crianças são selecionadas pelo professor Tiago de acordo com o conteúdo programático de aula trabalhado em conjunto com os demais professores. Nesse sentindo o professor exerce o papel de mediador da informação. Além de propiciar aos alunos contato com a informática e raciocínio lógico.

No decorrer da aula, os alunos demonstraram muito interesse nos jogos escolhidos por eles, alguns optaram por brincar de pega-pega, outros gostavam dos jogos, ajudavam os coleguinhas com dificuldades. $O$ aluno com deficiência se divertia com a monitora, apesar dele não conseguir manusear o mouse a profissional direcionava de acordo com as orientações dele, por vários momentos ele demonstrou muita alegria.

A escola, por meio do professor, avalia as atividades realizadas no laboratório utilizando os seguintes critérios da ficha formativa (ver anexo 4 e 5) no tópico de informática: participa com entusiasmo das atividades propostas; conhece 0 vocabulário informático; demonstra habilidade no manuseio do mouse; acompanha as atividades desenvolvidas coletivamente; atende os comandos de ordem e organização; apresenta raciocínio lógico no desenvolvimento das atividades;

Caso o aluno tenha sido avaliado negativamente ele receberá acompanhamento pela orientadora pedagógica e demais professores.

Observou-se como estratégia de comunicação e mediação da informação a seleção e utilização de jogos e vídeos transmitindo as informações às crianças e as ajudando fixar o conteúdo apresentado em sala. 


\subsection{PROPOSTA DE MODELO DE ESTRATÉGIA DE COMUNICAÇÃO E MEDIAÇÃO ENTRE A CRIANÇA DA PRIMEIRA INFANCIA E A INFORMAÇÃO DIGITAL}

Diante do conteúdo levantado e exposto na revisão de literatura, na análise dos dados e por este trabalho ser inerente à Ciência da Informação, ponderou-se a respeito da proposta de modelo experimental de estratégia de comunicação e mediação entre a criança da primeira infância e a informação digital na educação infantil.

Considerando de extrema relevância a escolha do tipo de informação pela criança.

Figura 18 Modelo de comunicação e mediação entre a criança e a informação

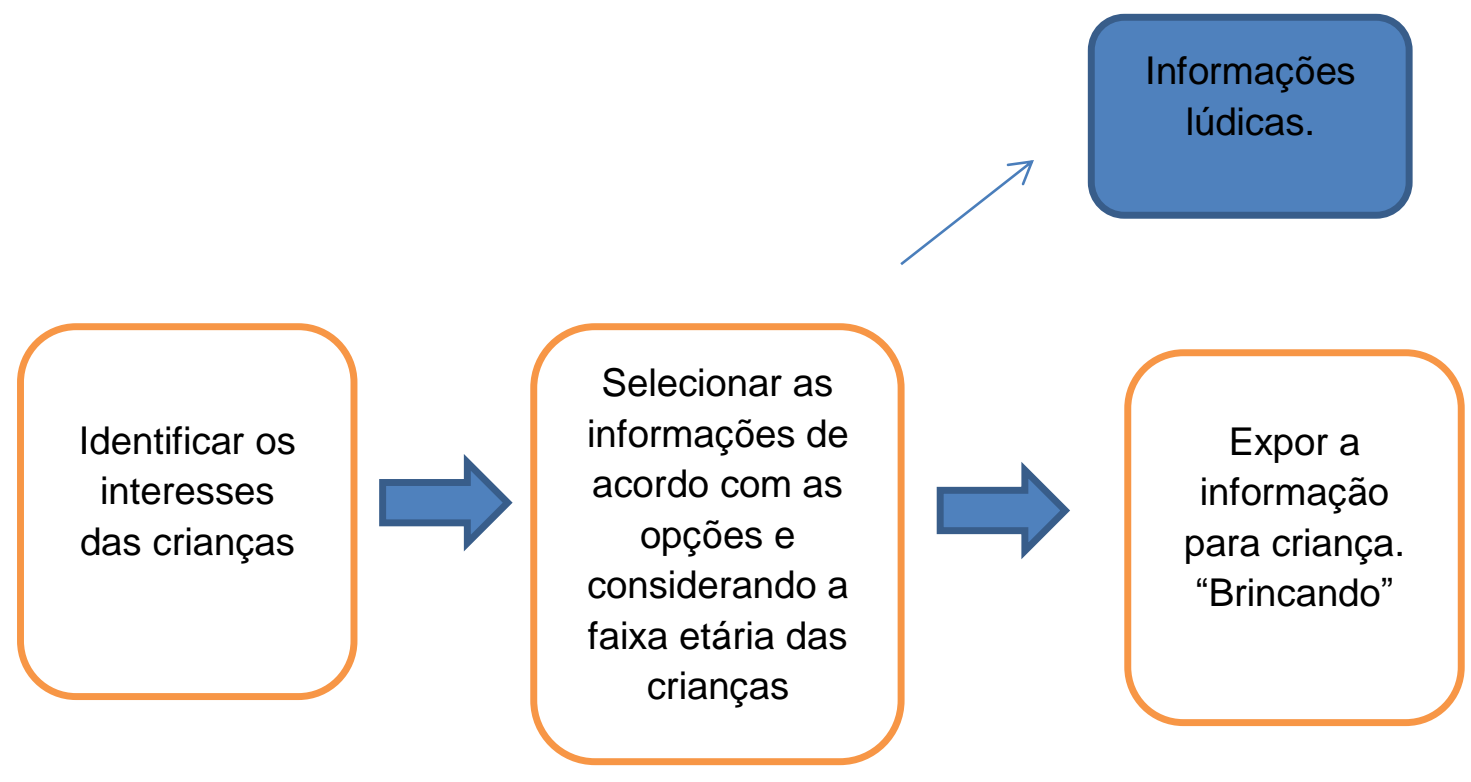

Fonte: elaboração própria

O modelo consiste nas três fases ilustradas acima. A primeira se baseia em identificar as informações de interesse da criança, ou seja, descobrir do que gosta e seus interesses. Na segunda etapa, o individuo responsável pela criança deverá selecionar as informações lúdicas e digitais de acordo com as respostas da primeira fase e considerando a idade da criança. A terceira e última fase é a transmissão da 
informação. O responsável, mediador, transmitirá de forma lúdica, brincando com as crianças, para que elas retenham e se divirtam acessando as informações. 


\section{CONSIDERAÇÕES FINAIS}

Devido às transformações ocorridas na sociedade em relação às crianças Percebeu-se que ainda é preciso estudar mais a respeito dos usuários de informação infantil e ao uso de informação digital, assim como comunicação e mediação da informação.

Conforme observado no estudo, as informações acessadas pelas crianças são de caráter lúdico e é transmitida por meio de jogos, vídeos, música e apresentações em power point.

Quanto à relação entre os objetivos propostos e respostas do estudo podem ser observados no quadro 16.

Quadro 16 Mapa de pesquisa

\begin{tabular}{|c|c|c|c|c|c|}
\hline \multicolumn{2}{|c|}{ Objetivo geral } & \multicolumn{4}{|c|}{$\begin{array}{c}\text { Identificar estratégias de comunicação e mediação entre a criança da primeira } \\
\text { infância e a informação digital na educação infantil. }\end{array}$} \\
\hline \multicolumn{2}{|c|}{$\begin{array}{l}\text { Objetivo } \\
\text { especifico }\end{array}$} & Variável & Participantes & Método de Coleta & Resultado \\
\hline OE1 & $\begin{array}{l}\text { Caracterizar } \\
\text { a informação } \\
\text { digital para } \\
\text { as crianças } \\
\text { da primeira } \\
\text { infância no } \\
\text { ambiente } \\
\text { escolar. }\end{array}$ & $\begin{array}{l}\text { Informação } \\
\text { digital que os } \\
\text { alunos } \\
\text { utilizam }\end{array}$ & $\begin{array}{l}\text { Crianças } \\
\text { entre } 3 \text { e } 5 \\
\text { anos dos } \\
\text { colégios } \\
\text { Ursinho } \\
\text { Dourado, } \\
\text { Fátima, Santa } \\
\text { Maria e La } \\
\text { Salle }\end{array}$ & $\begin{array}{l}\text { Questionário } \\
\text { infantil; } \\
\text { Observação de } \\
\text { atividades com } \\
\text { roteiro, observação } \\
\text { assistemática } \\
\text { entrevista informal } \\
\text { com professor do } \\
\text { La Salle; }\end{array}$ & $\begin{array}{l}\text { A característica da } \\
\text { informação utilizada } \\
\text { pela criança é de lúdica } \\
\text { e é transmitida por } \\
\text { jogos, vídeos, música, } \\
\text { apresentação de power } \\
\text { point. }\end{array}$ \\
\hline OE2 & $\begin{array}{l}\text { Descrever a } \\
\text { interação } \\
\text { das crianças } \\
\text { com a } \\
\text { informação } \\
\text { digital no } \\
\text { contexto } \\
\text { escolar. }\end{array}$ & $\begin{array}{l}\text { Interação } \\
\text { das crianças } \\
\text { com a } \\
\text { informação }\end{array}$ & $\begin{array}{l}\text { Crianças } \\
\text { entre } 3 \text { e } 5 \\
\text { anos dos } \\
\text { colégios } \\
\text { Ursinho } \\
\text { Dourado, } \\
\text { Fátima, Santa } \\
\text { Maria e La } \\
\text { Salle }\end{array}$ & $\begin{array}{l}\text { Observação de } \\
\text { atividades com } \\
\text { roteiro, observação } \\
\text { assistemática }\end{array}$ & $\begin{array}{l}\text { A interação ocorre entre } \\
\text { as crianças, professores } \\
\text { e informação digital. } \\
\text { Especificamente com a } \\
\text { informação digital, no } \\
\text { caso jogos, as reações } \\
\text { podem ser conferidas } \\
\text { nos quadros anteriores } \\
\text { correspondentes a cada } \\
\text { escola pesquisada. }\end{array}$ \\
\hline OE3 & $\begin{array}{l}\text { Descrever as } \\
\text { estratégias } \\
\text { de } \\
\text { comunicação } \\
\text { e mediação } \\
\text { da } \\
\text { informação } \\
\text { entre as }\end{array}$ & $\begin{array}{l}\text { Estratégias } \\
\text { de } \\
\text { comunicação } \\
\text { e mediação } \\
\text { da } \\
\text { informação } \\
\text { digital } \\
\text { utilizada }\end{array}$ & $\begin{array}{l}\text { Crianças } 4 \\
\text { anos colégio } \\
\text { La Salle de } \\
\text { Brasília }\end{array}$ & $\begin{array}{l}\text { Observação } \\
\text { assistemática da } \\
\text { aula de informática. }\end{array}$ & $\begin{array}{l}\text { As estratégias utilizadas } \\
\text { são atividades de } \\
\text { caráter lúdico livre ou } \\
\text { planejadas junto aos } \\
\text { professores. Notou-se } \\
\text { que há elementos } \\
\text { envolvidos no processo } \\
\text { de comunicação e }\end{array}$ \\
\hline
\end{tabular}




\begin{tabular}{|l|l|l|l|l|l|}
\hline $\begin{array}{l}\text { crianças da } \\
\text { primeira } \\
\text { infância e a } \\
\text { informação } \\
\text { digital. }\end{array}$ & $\begin{array}{l}\text { para as } \\
\text { crianças da } \\
\text { primeira } \\
\text { infância na } \\
\text { educação } \\
\text { infantil }\end{array}$ & & & $\begin{array}{l}\text { mediação da informação } \\
\text { digital, como citados no } \\
\text { quadro 3. }\end{array}$ \\
\hline
\end{tabular}

Fonte: Elaboração própria.

Atualmente, os profissionais que trabalham diretamente com usuários infantis têm de se desdobrarem para motivá-los e mantê-los interessados. Há muito para se conhecer em relação à tecnologia da comunicação e informação e a criança. Logo, a importância de estabelecer estratégias de comunicação e mediação da informação entre a criança da primeira infância e a informação digital.

Ao observar as interações das crianças entre elas e a informação digital, notou-se que, independente da escola, os pequenos brincam e interagem com qualquer atividade. Demonstram claramente suas preferências por meio do seu comportamento e das reações emocionais.

O reforço que as crianças têm com os jogos é significativo para seu aprendizado para fixarem o conteúdo exposto sala de aula convencional.

A comunicação está presente em toda comunidade escolar e é realizada por todos os elementos que a compõem e influenciam significativamente o aprender das crianças.

Os responsáveis pelas crianças na escola exercem o papel de mediadores da informação. Devem zelar para que não haja falhas nesse processo e propiciar aos pequenos acesso a informação de qualidade.

As estratégias de comunicação e mediação da informação é relevante devido aos processos de aprendizagem. 


\section{REFERÊNCIAS}

ALMEIDA JÚNIOR, Oswaldo Francisco. Mediação da informação e múltiplas linguagens. In: Pesquisa brasileira em ciência da informação. Brasília, v.2, n.1, p.89-103, jan./dez. 2009.

ARIÈS, Phillipe. História Social da Criança e da Família. Tradução de Dora Flaksman. 2.ed.Rio de Janeiro: LTC, 2006.

ATIVIDADES EDUCATIVAS. Disponível em:

<http://www.atividadeseducativas.com.br/>. Acesso em: 14 nov. 2014.

BARBOSA, Simone Diniz Junqueira; SILVA, Bruno Santana da. Interação humanocomputador. Rio de Janeiro: Elsevier, 2010.

BARROS, Tiago; SARMET, Mauricio; IIDA, Itiro. A conexão do design emocional no design. In: Estudos Avançados em Design, caderno 2, 2008. p.33-52. Disponível em: <http://www.tcdesign.uemg.br/pdf/Transversalidade_completo.pdf.> Acesso em: 30 jul. 2014.

BERLO, David. K. Comunicação: âmbito e objetivo. In: O processo de comunicação: introdução teoria e à prática. São Paulo: Martins Fontes, 2003.

BOCK, Ana Mercês Bahia; FURTADO, Odair; TEIXEIRA, Maria de Lourdes. Psicologias: uma introdução de psicologia. 14.ed. São Paulo: Saraiva, 2008.

BORKO, H. Information Science: What is it? American Documentation, v.19, n.1, p.3-5, Jan. 1968. (Tradução Livre). Disponível em:

<.http://disciplinas.stoa.usp.br/pluginfile.php/164799/mod_resource/content/1/BORK O_Information\%20science\%20what\%20is\%20it\%20.pdf> . Acesso em: 25 maio 2014.

BRASIL; MINISTÉRIO DA EDUCAÇÃO; SECRETARIA DE EDUCAÇÃO BÁSICA. Diretrizes curriculares nacionais para a educação infantil. Secretaria de educação básica . Brasília: MEC, SEB, 2010.

CEBALLOS, Maria Fernanda Pérez. Modelo de la espiral de Dance. Disponível em: http://prezi.com/igapaq8xyxra/modelo-de-la-espiral-de-dance. Acesso em: 20 out. 2014.

COCORICÓ. Disponível em: <http://cmais.com.br/cocorico>. Acesso em: 14 de nov. 2014.

COMITÊ GESTOR DA INTERNET NO BRASIL. Pesquisa sobre o uso de tecnologias de informação e comunicação no Brasil : TIC Crianças 2010. São Paulo: Comitê Gestor da Internet no Brasil, 2012.

CRESWELL, John W. Projeto de pesquisa: métodos qualitativo, quantitativo e misto. 3.ed. Porto Alegre: Artmed, 2010. 
CRUZ, Carla; RIBEIRO, Uirá. Metodologia científica: teoria e prática. Rio de Janeiro: Axcel books, 2003.

DEL NERO, Henrique Schützer. Ciências cognitivas. Disponível em: <http://www.lsi.usp.br/ hdelnero/JORN2.html> . Acesso em: 25 maio 2014.

. O sítio da mente: pensamento, emoção e vontade no cérebro humano. Disponível em: <http://www.delneroemaciel.med.br/sitio.htm> . Acesso em: 24 abr. 2014.

Complexos e complexidade. Estud. av., São Paulo, v. 8, n.

20, abr. 1994. Disponível em:

<http://www.scielo.br/scielo.php?script=sci_arttext\&pid=S0103-

40141994000100015\&lng=pt\&nrm=iso >. Acesso em: 06 nov. 2014.

DISCOVERY kids. Disponível em: < http://discoverykidsbrasil.uol.com.br/?cc=BR>. Acesso em 14 nov. 2014.

ECOKIDS. Disponível em:< http://www2.uol.com.br/ecokids/index.htm> Acesso em: 14 nov. 2014.

EDUCAÇÃO Infantil. Disponível em:< http://www.edinfjogos.universoneo.com.br/>. Acesso em: 14 nov. 2014.

ESCOLA Games. Disponível em: < http://www.escolagames.com.br/>. Acesso em: 14 nov. 2014.

FIGUEREDO, Carla J. O uso de estratégias de comunicação em sala de aula de língua inglesa: a interação em foco. In: Signótica. v.15, n.2, p.173-194, jul./dez. 2003. Disponível em: http://www.revistas.ufg.br/index.php/sig/article/view/3757 . Acesso em: 25 abr. 2015.

FRIEDMANN, Adriana. O universo simbólico da criança: olhares sensíveis para a infância. Petrópolis: Vozes, 2005.

FRIV. Disponível em: www.friv.com. Acesso em: 10 out. 2014.

GABRIEL, Martha. Educar: a (r) evolução digital na educação. São Paulo: Saraiva, 2013.

GARDNER, Howard. A nova ciência da mente: uma história da revolução cognitiva. São Paulo: EDUSP, 1996.

GROLLA, Elaine. A aquisição da linguagem. In: Material didático desenvolvido para o Curso Letras LIBRAS (UFSC), 2006.

JOGOS educativos. Disponível em:< http://jogoseducativos.jogosja.com/>. Acesso em: 14 nov. 2014.

JOGOS para crianças. Disponível em:< http://criancas.jogospara.com/>. Acesso em: 14 nov. 2014. 
LAGAR, Fabiana Margarita Gomes; SANTANA, Bárbara Beatriz de; DUTRA, Rosimeire. Fundamentos da educação. In: Conhecimentos pedagógicos para concursos. 2.ed. Editora Gran Cursos: Brasília, 2012. p.15-36.

LAMEIRA, A. K. A. ; KAFURE, Ivette . Informação lúdica como ferramenta de aprendizado para nativos digitais. 2013. (Apresentação de Trabalho/Iniciação Científica).

LE COADIC, Yves-François. A ciência da informação. 2.ed. Brasília: Briquet de Lemos/Livros,

2004.

LEITÃO, Sergio Proença; FORTUNATO, Graziela; FREITAS, Angilberto Sabino. Relacionamentos interpessoais e emoções nas organizações: uma visão biológica. RAP. n.40, v.5, p.883-907, set./out., 2006.

MARCONI, Maria de Andrade; LAKATOS, Eva Maria. Metodologia científica. 6.ed. São Paulo: Atlas, 2011.

MOUSINHO, Renata et al . Aquisição e desenvolvimento da linguagem: dificuldades que podem surgir neste percurso. Rev. psicopedag., São Paulo, v. 25, n. 78, 2008. Disponível em <http://pepsic.bvsalud.org/scielo.php?script=sci_arttext\&pid=S0103$84862008000300012 \&$ Ing=pt\&nrm=iso>. acessos em 27 jun. 2015.

MCQUAIL, D. ; WINDAHL, S. Communication models for the study of mass communication. 2.ed. Londres: Longman, 1993.

MENDONÇA, Ana Valéria Machado. Os processos de comunicação e o modelo de todos-todos: uma relação possível com o programa de saúde família. Brasília: Editora do Departamento de Ciência da Informação e Documentação da Universidade de Brasília, 2007.

MIRANDA, Antônio Lisboa; MENDONÇA, Ana Valéria Machado. O processo de comunicação aplicado à inclusão digital: produção de conteúdos, estudos de recepção e mediação à luz da Ciência da Informação. 2006. Disponível em: <http://www.intercom.org.br/papers/nacionais/2006/resumos/r0046-1.pdf.> Acesso em: 23 ago. 2014.

MYERS, David G. Psicologia. Tradução de Daniel Argolo Estill; Heitor M. Corrêa. 9.ed. Rio de Janeiro: LTC, 2014.

NERY, Maria da Penha. Vínculo e afetividade: caminhos das relações humanas. São Paulo: Ágora, 2003.

NEWCOMBE, Nora. Desenvolvimento infantil: abordagem de Mussen. 8.ed. Porto Alegre: Artmed, 1999. 
NIELSEN, Jackob. Usability of websites for children. 2010. Disponível em: < http://www.nngroup.com/articles/childrens-websites-usability-issues/> . Acesso em: 20 maio 2013.

PASSERINO, L. M. Informática na Educação Infantil: perspectivas e possibilidades. In: ROMAN, E. D.; STEYER, V. E. (Org.) A criança de $\mathbf{0}$ a 6 anos e a Educação Infantil: um retrato multifacetado. Canoas: UFRGS, 2001.

PEREIRA, F. Necessidades e usos da informação: a influência dos fatores cognitivos, emocionais e situacionais no comportamento informacional de gerentes. In: Perspectivas em Ciência da Informação. v. 15 n.3 Belo Horizonte, MG: UFMG, 2010.

PIAGET Jean. Os seis estudos de psicologia. Tradução Maria Alice Magalhães D’Amorim e Paulo Ségio Lima Silva. 24.ed. Rio de Janeiro: Forense Universitária, 1999.

POZAS, Denise. Criança que brinca mais aprende mais: a importância da atividade lúdica para o desenvolvimento cognitivo infantil. Rio de Janeiro: Senac Rio, 2011.

PRENSKY, Marc. Digital Natives. Disponível em: <http://marcprensky.com/digitalnative/> . Acesso em: 10 jan. 2014.

RODRIGUES, V. R. A interação entre à criança da primeira infância e a informação digital. 2012. 67 f. Monografia (Bacharelado em Biblioteconomia) Departamento da Faculdade de Ciência da Informação, Universidade de Brasília. Brasília, 2012.

., MENDES, Y. D., KAFURE, I. A interação entre a criança da primeira infância e a informação digital: estudo comparativo em duas escolas no Distrito Federal. In: Congresso Brasileiro de Biblioteconomia, Documentação e Ciência da Informação, 25, 2013 Florianópolis, XXV CBBD, (Anais) Florianópolis, SC, FEBAB, 2013, p.1563 - 1578.

SANTOS, Izequias E. dos S. Textos selecionados de métodos e técnicas de pesquisa científica. 3.ed. Rio de Janeiro: Impetus, 2001.

.; KAFURE, I. A interação entre à criança da primeira infância e a informação digital. In: Biblionline, João Pessoa, v. 9, n. 2, p. 79-95, 2013.

SEBER, Maria da Glória. Como a inteligência se desenvolve. In: Construção da inteligência pela criança: atividades do período pré-operatório. 2.ed. São Paulo: Scipione, 1991. p.13-42

SENNINHA. Disponível em:< http://senna.globo.com/senninha/index.asp >. Acesso em: 14 nov 2014.

SOUZA, Alessandra, CAMURUGY, Laiza, ALVES, Lynn. Games e gênero: a emergência dos personagens femininos. Disponível em: < 
http://www.sbgames.org/papers/sbgames09/culture/short/cults10_09.pdf>. Acesso em: 19 out. 2014.

STRAUSS, Ansel; CORBIN, Juliet. Pesquisa qualitativa: técnicas e procedimentos para o desenvolvimento de teoria fundamentada. Tradução: Luciane de Oliveira Rocha. 2.ed. Porto Alegre: Artmed, 2008.

TUBBS, S. L.; MOSS, S. Human communication: principles and contexts. 9. ed. Boston: McGraw Hill, 2003.

TVRATIMBUM. Disponível em:<http://tvratimbum.cmais.com.br/>. Acesso em: 14 nov. 2014.

VYGOTSKY, L. S. A formação social da mente. Rio de Janeiro: Martins Fontes, 1998.

WADSWORTH, Barry J. Inteligência e afetividade da criança na teoria de Piaget. Tradução de Esméria Rovai. 3.ed. São Paulo: Pioneira, 1995. 


\section{ANEXOS}

\section{ANEXO 1 - Aceite institucional Colégio Santa Maria}

\section{ACEITE INSTITUCIONAL}

A Sra. Ilma Barbosa dos Santos do Colégio Santa Maria, está de acordo com a realização da pesquisa CRIANÇA DA PRIMEIRA INFÂNCIA E O USO DA INFORMAÇÃO DIGITAL NA EDUCAÇÃO INFANTIL, de responsabilidade da pesquisadora Vivianne da Rocha Rodrigues aluna de mestrado na Faculdade de Ciência da Informação Programa de pós-graduação em Ciência da Informação da Universidade de Brasília, realizado sob orientação de Ivette Kafure Muñoz após revisão e aprovação pelo Comitê de Ética em Pesquisa do Instituto de Ciências Humanas da Universidade de Brasília - CEP/IH.

O estudo envolve a realização de pesquisa qualitativa utilizando como métodos de coletas de dados observação assistemática (o pesquisador atua somente como expectador) e entrevista não estruturada com estudantes da educação infantil entre 3 e 5 anos. A pesquisa terá a duração de duas semanas, com previsão de início em 05/2014 e término em 11/2014.

Eu, Ilma Barbosa dos Santos, Diretora do Colégio Santa Maria, declaro conhecer e cumprir as Resoluções Éticas Brasileiras, em especial a Resolução CNS 196/96. Esta instituição está ciente de suas co-responsabilidades como instituição co-participante do presente projeto de pesquisa, e de seu compromisso no resguardo da segurança e bem-estar dos sujeitos de pesquisa nela recrutados, dispondo de infra-estrutura necessária para a garantia de tal segurança e bem-estar.

Brasília, 9 de Out de 2014.

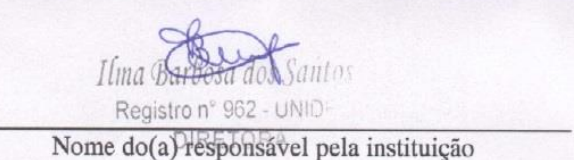
instituição
Assinatura e carimbo do(a) responsável pela 


\section{ANEXO 2 - Aceite institucional Colégio La Salle Brasília}

\section{ACEITE INSTITUCIONAL}

A Sra. Ivana Carvalho de Araújo de Oliveira do Colégio La Salle Brasilia, está de acordo com a realização da pesquisa CRIANÇA DA PRIMEIRA INFÂNCIA E O USO DA INFORMAÇÃO DIGITAL NA EDUCAÇÃO INFANTIL, de responsabilidade da pesquisadora Vivianne da Rocha Rodrigues aluna de mestrado na Faculdade de Ciência da Informação Programa de pós-graduação em Ciência da Informação da Universidade de Brasília, realizado sob orientação de Ivette Kafure Muñoz após revisão e aprovação pelo Comitê de Ética em Pesquisa do Instituto de Ciências Humanas da Universidade de Brasília - CEP/IH.

O estudo envolve a realização de pesquisa qualitativa utilizando como métodos de coletas de dados observação assistemática (o pesquisador atua somente como expectador) e entrevista não estruturada com estudantes da educação infantil entre 3 e 5 anos. A pesquisa terá a duração de duas semanas, com previsão de início em 09/2014 e término em 09/2014.

$\mathrm{Eu}$, Ivana Carvalho de Araújo de Oliveira, Coordenadora Geral do Colégio La Salle Brasilia, declaro conhecer e cumprir as Resoluções Éticas Brasileiras, em especial a Resolução CNS 196/96. Esta instituição está ciente de suas co-responsabilidades como instituição co-participante do presente projeto de pesquisa, e de seu compromisso no resguardo da segurança e bem-estar dos sujeitos de pesquisa nela recrutados, dispondo de infra-estrutura necessária para a garantia de tal segurança e bem-estar.

Brasilia, 19 de agosto de 2014.
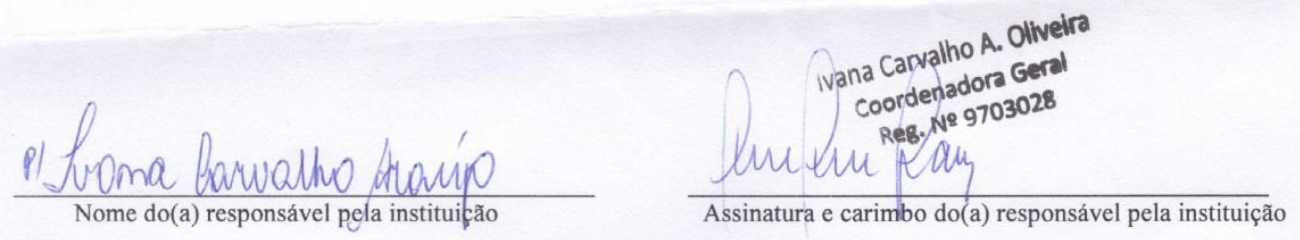

$$
\Gamma_{60916731 / 0009-60}^{\text {INSCRIÇÃO NO CNPJ }}
$$$$
\text { Associação Brasilieira de Educadores }
$$$$
\text { Lassalistas - Colégio La Salle Brasilia }
$$$$
\text { SGAS Quadra } 906 \text { Conjunto E }
$$$$
\text { Asa Sul - CEP: } 70390.060
$$

$L$ BRASILIA.DF 
ANEXO 3 - Documento de solicitação para realização de pré-testes nas instituições.

\section{Universidade de Brasília}

Programa de Pós-Graduação em Ciência da Informação

Mestrado em Ciência da Informação

Grupo de Pesquisa: Informação, Design e Usabilidade

Pesquisadora: Vivianne da Rocha Rodrigues

Orientador: Ivette Kafure Muñoz

\section{SOLICITAÇÃO}

Prezado (a) Senhor (a):

Solicito a colaboração desta instituição, caso seja possível, possibilitando a realização do estudo que servirá de insumo para dissertação de Mestrado em Ciência da Informação da Faculdade de Ciência da Informação da Universidade de Brasília.

INFORMAÇÕES SOBRE A PESQUISA:

Título: NECESSIDADES DE INFORMAÇ̃̃O DA CRIANÇA DA PRIMEIRA

INFÂNCIA NA INTERAÇÃO COM A INFORMAÇÃO DIGITAL.

Pesquisador Responsável: VIVIANNE DA ROCHA RODRIGUES

Orientador: IVETTE KAFURE MUÑOZ

A pesquisa tem a intenção de IDENTIFICAR AS NECESSIDADES DE INFORMAÇÃO DA CRIANÇA DA PRIMEIRA INFÂNCIA NA INTERAÇÃO COM A INFORMAÇÃO DIGITAL. Para que a mesma seja alcançada os métodos serão observação das crianças da educação infantil durante aula de informática; entrevista com o responsável pelo planejamento e aula.

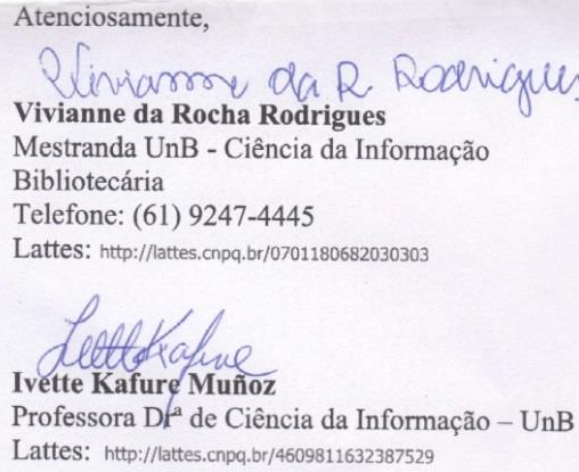


ANEXO 4 - Ficha avaliativa de atividades extras do La Salle do Infantil IV

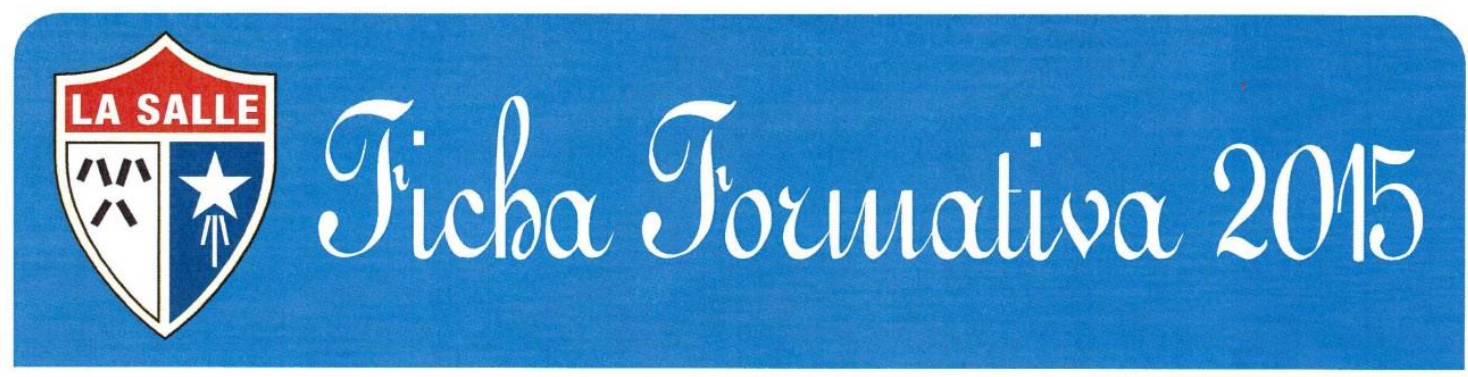

Aluno (a):

S Sim

Turma:

$\mathrm{N}$ Não

ED Em Desenvolvimento

\section{Psicomotricidade}

\begin{tabular}{|l|l|}
\hline Participa das atividades propostas & \\
\hline Presta atenção nas atividades propostas & \\
\hline Espera a sua vez de participar das atividades & \\
\hline Demonstra insegurança ao executar determinadas atividades & \\
\hline Atende aos comandos das atividades & \\
\hline Utiliza a criatividade como elemento de apoio ás atividades propostas & \\
\hline Atende aos comandos de ordem e organização & \\
\hline Esquematização Corporal Satisfatória & \\
\hline Percepção Corporal satisfatória & \\
\hline Lateralidade satisfatória & \\
\hline Orientação Espacial satisfatória & \\
\hline Orientação Temporal satisfatória & \\
\hline Ritmo satisfatório & \\
\hline
\end{tabular}

\section{Música}

Participa das canções e dramatizações propostas

Atenta-se as canções propostas

Canta em conjunto seguido de comando

Demonstra boa memória auditiva

Participa com entusiasmo das atividades musicais

\section{Informática}

Participa com entusiasmo das atividades propostas

Conhece o vocabulário informático

Demonstra habilidade no manuseio do mouse

Acompanha as atividades desenvolvidas coletivamente

Atende aos comandos de ordem e organização

Apresenta raciocínio lógico no desenvolvimento das atividades

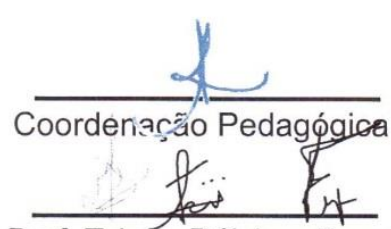

Prof: Telma, Délcio e Fernando

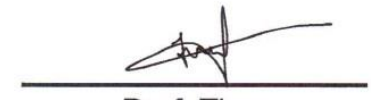

Prof: T'ago

Prof: Clarissa

\section{Infantil 4}

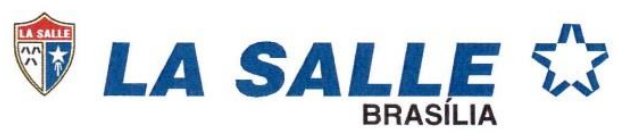


ANEXO 5 - Ficha avaliativa de atividades extras do La Salle Infantil V

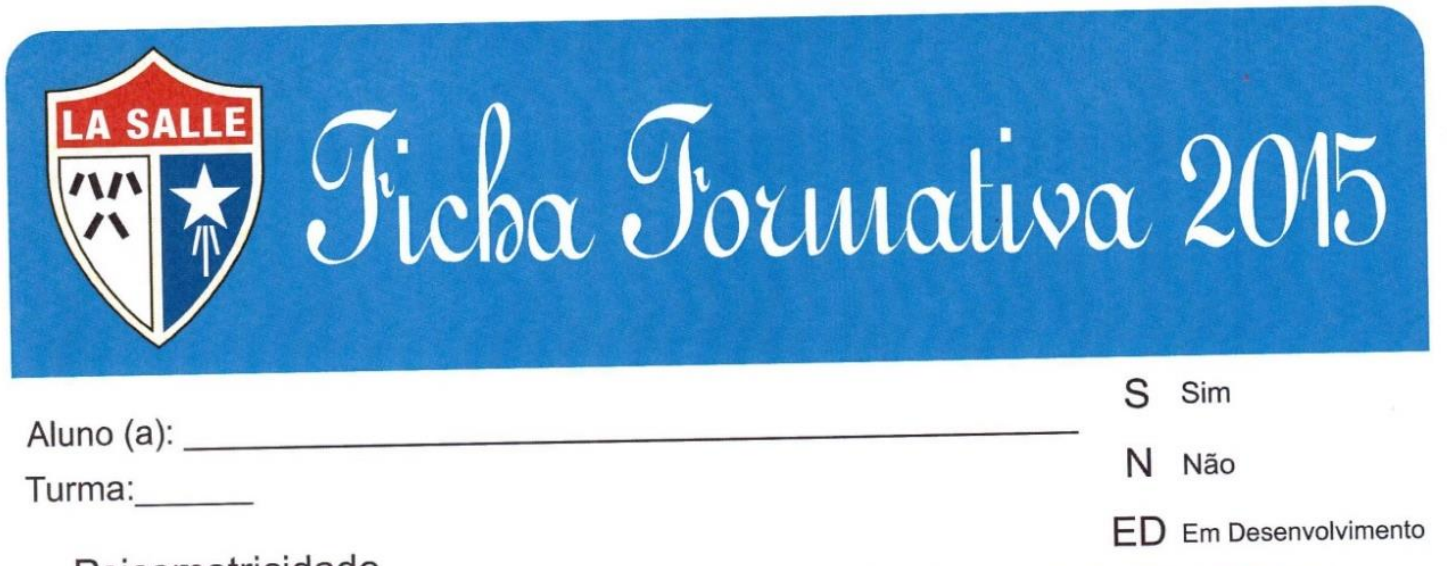

Psicomotricidade

Participa das atividades propostas

Presta atenção nas atividades propostas

Espera a sua vez de participar das atividades

Demonstra insegurança ao executar determinadas atividades

Atende aos comandos das atividades

Utiliza a criatividade como elemento de apoio ás atividades propostas

Atende aos comandos de ordem e organização

Esquematização Corporal Satisfatória

Percepção Corporal satisfatória

Lateralidade satisfatória

Orientação Espacial satisfatória

Orientação Temporal satisfatória

Ritmo satisfatório

Música

Participa das canções e dramatizações propostas

Atenta-se as canções propostas

Canta em conjunto seguido de comando

Demonstra boa memória auditiva

Participa com entusiasmo das atividades musicais

Informática

Participa com entusiasmo das atividades propostas

Conhece o vocabulário informático

Demonstra habilidade no manuseio do mouse

Acompanha as atividades desenvolvidas coletivamente

Atende aos comandos de ordem e organização

Apresenta raciocínio lógico no desenvolvimento das atividades

Inglês

Desenvolve as atividades propostas

Realiza os trabalhos com colagem e recorte

Pronuncia as palavras adequadamente

Demostra interesse pela disciplina

Consegue terminar as atividades em tempo hábi

Permanece motivado durante as atividades

Atende aos comandos de ordem e organização

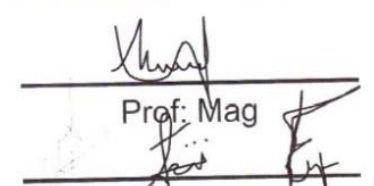

Prof: Telma, Délcio e Fernando

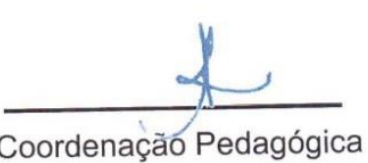

Coordenação Pedagógica

\section{Infantil 5}

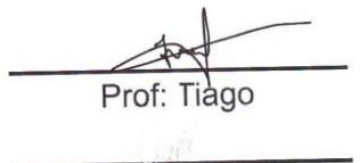

Prof: Clarissa

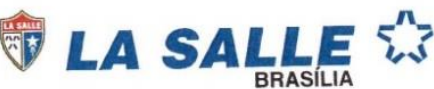


ANEXO 6 - Solicitação para coleta final
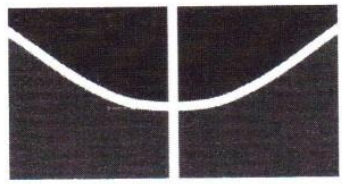

Universidade de Brasília - UnB

Programa de Pós-Graduação em Ciência da Informação

Mestrado em Ciência da Informação

Grupo de Pesquisa: Fatores Humanos na Interação e Comunicação da

Informação - FHICl

\section{Solicitação}

Prezado (a) Senhor (a):

Solicito a colaboração desta instituição, caso seja possivel, autorização para realização do estudo que servirá de insumo para dissertação de mestrado em Ciência da Informação do Programa Pós-Graduação em Ciência da Informação da Universidade de Brasília.

INFORMAÇÕES SOBRE A PESQUISA:

Título: Comunicação e mediação entre a criança da primeira infância e a informação digital na educação infantil

Pesquisador Responsável: Vivianne da Rocha Rodrigues

Orientador: Ivette Kafure Muñoz

A pesquisa tem como objetivo Identificar estratégias de comunicação e mediação entre a criança da primeira infância e a informação digital na educação infantil. Para que a mesma seja alcançada os métodos serão observação das crianças da educação infantil durante a aula de informática e possivel entrevista com alunos e responsáveis pelos mesmos.

Respeitosamente,

\section{Shivime da 2. Pochigus}

Vivianne da Rocha Rodrigues

Mestranda UnB

Bibliotecária

Tel: (61) 9247-4445

Lattes: http://lattes.cnpq.br/0701180682030303

\section{ivette Kafure Muñoz}

Professora Dra. Faculdade Ciência da Informação da UnB

Lattes: http://lattes.cnpq.br/4609811632387529 
ANEXO 7 - Aceite Institucional do La Salle Brasília para coleta final

\title{
ACEITE INSTITUCIONAL
}

A Sra. Ivana Carvalho de Araújo do Colégio La Salle Brasilla, está de acordo com a realizaçăo da pesquisa COMUNICAÇÃO E MEDIAÇÃO ENTRE A CRIANÇA DA PRIMEIRA INFÂNCIA E A INFORMAÇÃO DIGITAL NA EDUCAÇÃO INFANTIL de responsabilidade da pesquisadora Vivianne da Rocha Rodrigues aluna de mestrado na Faculdade de Ciência da Informação Programa de pós-graduação em Ciência da Informação da Universidade de Brasilia, realizado sob orientação de Ivette Kafure Muñoz.

O estudo envolve a realização de pesquisa qualitativa utilizando como métodos de coletas de dados observação assistemática (o pesquisador atua somente como expectador) e entrevista nđo estruturada com estudantes da educação infantil entre 3 e 5 anos. A pesquisa terá a duração de duas semanas, com previsão de início em 09/2015 e término em 09/2015.

Eu, Ivana Carvalho de Araújo, Coordenadora Geral do Colégio La Salle Brasillia, declaro conhecer e cumprir as Resoluções Éticas Brasileiras, em especial a Resolução CNS 196/96. Esta instituição está ciente de suas co-responsabilidades como instituição co-participante do presente projeto de pesquisa, e de seu compromisso no resguardo da segurança e bem-estar dos sujeitos de pesquisa nela recrutados, dispondo de infra-estrutura necessária para a garantia de tal segurança e bem-estar.

Brasília, 29 de abril de 2015.
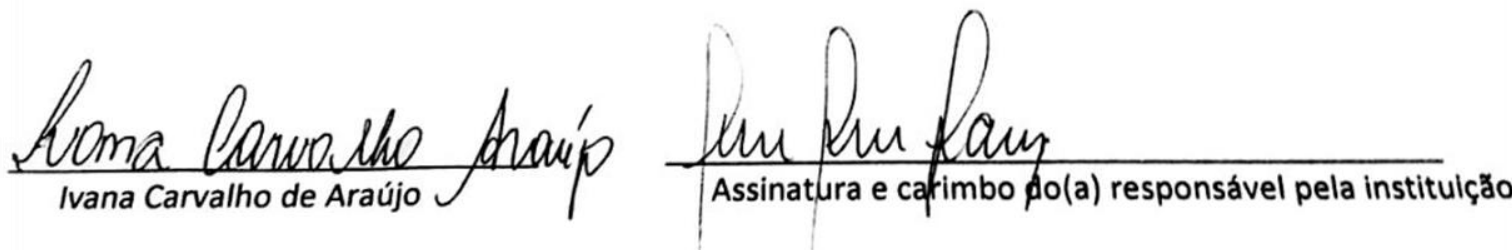

\author{
WANA EARVAL HO ARAIHO \\ COORDENADORA GERAL \\ COLGGIOLA SALE BRASILLA \\ REB 9 9T03028
}

